MARCIO ALVES SANJAR

\title{
ASPECTOS JURÍDICOS SOCIETÁRIOS DOS PLANOS DE OPÇÃO DE COMPRA DE AÇÕES
}

\author{
DISSERTAÇÃO DE MESTRADO
}

FACULDADE DE DIREITO DA UNIVERSIDADE DE SÃO PAULO

SÃO PAULO

2012 
MARCIO ALVES SANJAR

\section{ASPECTOS JURÍDICOS SOCIETÁRIOS DOS PLANOS DE OPÇÃO DE COMPRA DE AÇÕES}

Dissertação apresentada ao Curso de PósGraduação stricto sensu da Faculdade de Direito da Universidade de São Paulo, na área de concentração do Departamento de Direito Comercial, como requisito parcial à obtenção do título de Mestre em Direito.

Orientador: Prof. Dr. Haroldo Malheiros Duclerc Verçosa 
BANCA EXAMINADORA

Prof. Dr. Haroldo Malheiros Duclerc Verçosa (Orientador) 
Dedico este trabalho aos meus queridos pais, por todo o incentivo e apoio. 


\section{AGRADECIMENTOS}

Meus sinceros agradecimentos ao Prof. Dr. Haroldo Malheiros Duclerc Verçosa, pela confiança e atenção depositadas desde o início.

À Professora Dra. Rachel Sztajn e ao Professor Dr. Marcos Paulo de Almeida Salles, pela colaboração no exame de qualificação e pelos valiosos comentários e sugestões oferecidos.

À Rosana e à Cacilda, do Departamento de Direito Comercial, pela compreensão, paciência e ajuda.

Aos meus pais e irmãs, que sempre me proporcionaram um ambiente familiar sólido e estável, nunca medindo esforços para garantir as condições emocionais e financeiras que me possibilitaram continuar os estudos acadêmicos. 


\section{RESUMO}

A presente dissertação tem por finalidade a análise dos principais aspectos jurídicos societários do tratamento dado aos planos de opção de compra de ações de emissão de sociedades por ações - comumente designados stock option plans -, especialmente quanto aos planos adotados por companhias abertas brasileiras.

Para tanto, o estudo se inicia com a contextualização dos planos de opção no Brasil em face da chamada Teoria da Agência, bem como das normas atualmente aplicáveis ao referido instituto. Em seguida, por se tratar de questão intimamente relacionada, são discutidos determinados aspectos sobre a eventual natureza trabalhista dos planos de opção, para, então, proceder-se à análise das principais características dos stock option plans.

Por fim, é apresentado o panorama atual das companhias abertas brasileiras que possuem um plano de opção aprovado por seus acionistas, como esforço da caracterização da evolução da forma de remuneração variável no Brasil.

Palavras-chave: direito societário; sociedades por ações; plano de opção de compra; remuneração variável. 


\begin{abstract}
This dissertation aims the analysis of the main corporate legal aspects of corporation's stock option plans, particularly with regards the plans adopted by Brazilian publicly held companies.

To this end, the study begins with the background of the option plans in Brazil in the face of the so-called agency theory, as well as the currently rules applicable thereto. Thereafter, are discussed certain aspects involving the eventual labor nature of the stock option plans, as well as their main characteristics.

Finally, the study presents the current panorama of Brazilian companies that have an option plan approved by its shareholders, as an effort to illustrate the evolution of the variable compensation in Brazil.
\end{abstract}

Keywords: corporate law; corporations; stock option plans; variable remuneration. 


\section{SIGLAS E ABREVIATURAS}

BM\&FBovespa

Código Civil Brasileiro

CEO

CLT

CVM

IBGC

Instrução CVM n 323

Instrução CVM n ${ }^{0} 358$

Instrução CVM n 390

Instrução CVM n ${ }^{\circ} 480$

Lei das Sociedades por Ações

SAR
Bolsa de Valores, Mercadorias e Futuros de São Paulo.

Lei $\mathrm{n}^{0}$ 10.416, de 11 de janeiro de 2002, conforme alterada, que instituiu o Código Civil.

Chief Executive Officer

Consolidação das Leis do Trabalho

Comissão de Valores Mobiliários.

Instituto Brasileiro de Governança Corporativa

Instrução da CVM n ${ }^{\circ}$ 323, de 19 de janeiro de 2000, conforme alterada.

Instrução da CVM n ${ }^{0}$ 358, de 3 de janeiro de 2002, conforme alterada.

Instrução da CVM n ${ }^{0}$ 390, de 9 de julho de 2003, conforme alterada.

Instrução da CVM n 480, de 7 de dezembro de 2009, conforme alterada.

Lei $n^{\circ}$ 6.404, de 15 de dezembro de 1976, conforme alterada, que dispõe sobre as sociedades por ações.

stock appreciation right 


\section{SUMÁRIO}

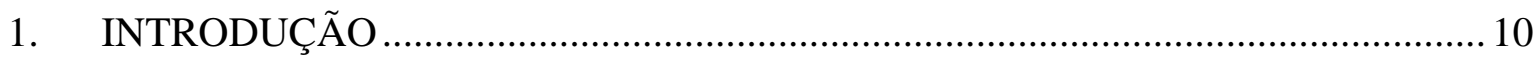

PRIMEIRA PARTE - CONCEITOS E FUNDAMENTOS.................................................... 16

2. PANORAMA SOCIETÁRIO E GOVERNANÇA CORPORATIVA ..........................17

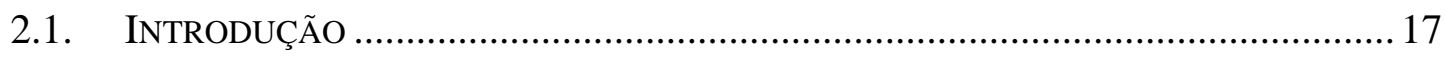

2.2. Estrutura de Propriedade da Sociedade ...................................................... 21

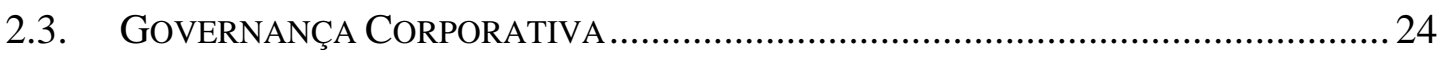

2.3.1. RELAÇÃO DE AGÊNCIA .................................................................................... 27

2.3.1.1. Custos de Monitoramento (Monitoring Expenditures) ...................................30

2.3.1.2. Custos de Incentivo (Bonding Expeditures) ……………………………..... 30

2.3.1.3. Perdas Residuais (Residual Loss) ……………………………………....... 31

3. DEVERES E RESPONSABILIDADES DOS ADMINISTRADORES ………….......34

3.1. DEVER DE DILIGÊNCIA.................................................................................... 35

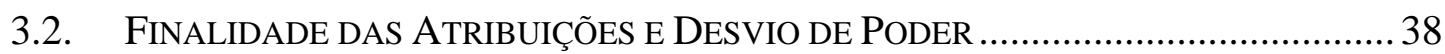

3.3. DEVER DE LEALDADE ................................................................................ 40

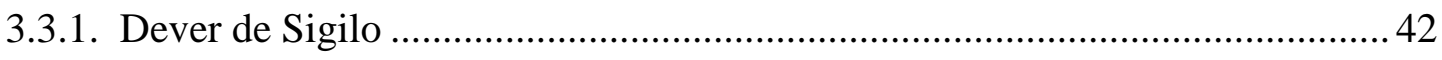

3.4. CONFLITO DE INTERESSES................................................................................ 43

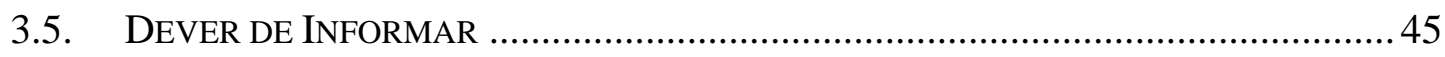

4. CAPITAL AUTORIZADO …………………………………………………..... 48

4.1. CARACTERÍSTICAS FUNDAMENTAIS .................................................................. 48

4.2. EMISSÃo DE AÇÕES NOS LIMITES DA AUTORIZAÇÃO........................................... 49

4.3. DIREITO DE PREFERÊNCIA................................................................................. 51

4.4. Modalidades Afins de RemuneraçÃo Baseada Em AÇões........................... 53 
SEGUNDA PARTE - OS PLANOS DE OPÇÃO DE COMPRA DE AÇÕES

5. PLANOS DE OPÇÃO DE COMPRA DE AÇÕES ............................................. 58

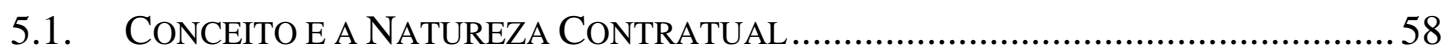

5.1.1. Natureza Salarial x Natureza Comercial.......................................................63 63

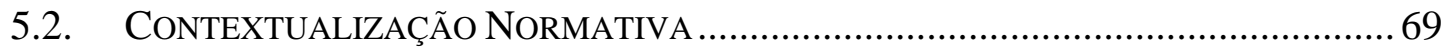

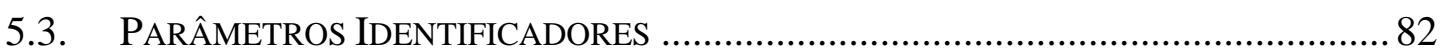

5.3.1. Diferenciação entre os Planos de Opção e os Bônus de Subscrição................. 86

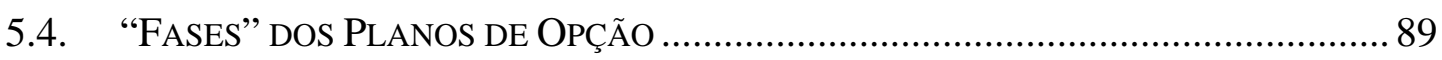

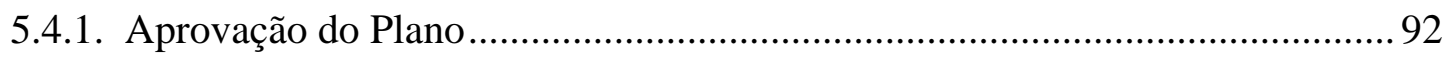

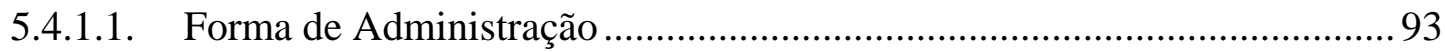

5.4.1.2. Elegibilidade e Critérios.............................................................................. 94

5.4.1.3. Diminuição de Participação Acionária........................................................ 96

5.4.2. Período de Carência (Vesting Period) ........................................................... 97

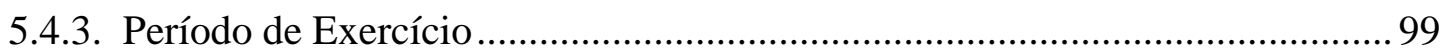

5.4.3.1. Preço de Exercício e Forma de Fixação ...................................................... 102

5.5. Os Planos de OpÇão e as Companhias Abertas Brasileiras................... 105

5.5.1. Os Planos de Opção e a Estrutura Familiar .................................................. 109

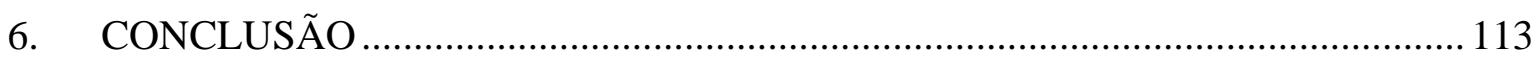

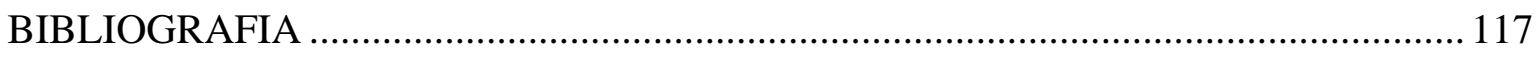

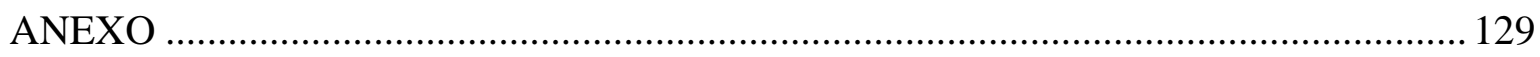


Na última década, os escândalos envolvendo empresas norte-americanas em decorrência da manipulação de balanços chamaram grande atenção para a utilização abusiva de planos de opção de compra de ações por parte de administradores e determinados empregados. A partir de então, acendeu-se um sinal de alerta para a utilização e regulação desse mecanismo de remuneração baseada em ações e foram retomadas, de certa forma, as discussões ocorridas após o crash da bolsa de Nova Iorque em 1929 envolvendo a questão da regulação (ou não) do mercado de valores mobiliários ${ }^{1}$.

Em resposta a tais escândalos, os planos de opção de ações passaram a ser regulados de forma mais rígida não só nos Estados Unidos, onde tal instrumento foi originalmente mais utilizado, mas também em outros países. No Brasil, por exemplo, a Instrução CVM n 480 estipulou que uma série de informações em relação aos planos deve ser disponibilizada ao público e atualizada com frequência ${ }^{2}$.

No entanto, não só as consequências da utilização indevida dos planos de opção de ações devem ser analisadas, mas também a origem de tais planos de opção, sua evolução e os benefícios deles decorrentes. O reconhecimento da importância dos planos de opção como forma de remuneração variável e a ausência de um regramento específico, bem como a necessidade de se entender o seu devido funcionamento a fim de evitar abusos, motivaram a elaboração deste trabalho.

\footnotetext{
1 Logo após o crash de 1929, foram promulgadas nos Estados Unidos uma série de medidas (acts) com vistas à regulação do mercado. Entre os contrários a essas medidas, é possível citar STIGLER, George J. Public regulation of securities market. Journal of Business, v. 37, p. 117-142, 1964; e BENSTON, George. Required disclosure and the stock market: an evaluation of the Securities Exchange Act of 1934. American Economic Review, v. 63, p. 132-155, 1973. A favor, em contraposição à análise dos referidos autores, Érica Cristina Rocha Gorga aponta o trabalho de Joel Seligman, que analisa cinco argumentos em pró da regulação, em especial a prestação de informações: “1) os emitentes de valores mobiliários podem ocultar ou forjar informações materiais para a decisão de investimento, 2) os custos de subscrição (underwriting), os salários e benefícios (perquisites) dos administradores serão excessivos, 3) a confiança do público nos mercados será menor, 4) nem leis estaduais nem associações privadas como a Bolsa de Valores de Nova Iorque podem assegurar um nível ótimo de divulgação de informações, 5) ações civis ou criminais não assegurarão níveis ótimos de divulgação de informações das empresas”. GORGA, Érica Cristina Rocha. Direito Societário brasileiro e desenvolvimento do mercado de capitais: uma perspectiva de "Direito e Economia". São Paulo, 2005. 315 f. Tese (Doutorado em Direito). Faculdade de Direito, Universidade de São Paulo. p. 158.

2 Por exemplo, devem ser informados os critérios e eventos que, quando verificados, ocasionarão a suspensão, alteração ou extinção do plano; as condições para aquisição de ações; os critérios para fixação do preço de aquisição ou exercício; e as restrições à transferência das ações.
} 
Nesse sentido, a presente dissertação tem como objetivo a análise dos principais aspectos jurídicos societários do tratamento dado aos planos de opção de compra de ações, comumente designados stock options plans. Para tanto, o trabalho será elaborado tendo em vista a atual evolução da estrutura de propriedade nas sociedades por ações brasileiras, sobretudo em decorrência da aplicabilidade das práticas de governança corporativa e do desenvolvimento do mercado de capitais nacional.

Assim, o tema, já amplamente abordado pela doutrina estrangeira, será analisado principalmente sob a perspectiva do direito societário, não obstante a existência de outros aspectos, como os de ordem trabalhista e tributária, também envolvidos ${ }^{3}$. Essa limitação se justifica pela própria natureza jurídica dos planos de opção de compra de ações, bem como pela necessidade de se fazer um estudo objetivo e focado. Pretende-se oferecer uma apresentação completa do panorama societário envolvendo a problemática da aprovação de planos de opção de compra de ações nas sociedades por ações e dos interesses de acionistas, administradores e empregados quando inseridos no convívio social e em face das práticas de mercado recomendadas.

Desta forma, sem prejuízo do necessário exame da legislação comparada, será empreendida um análise com destaque para os requisitos, características e peculiaridades dos stock options plans, entre outras questões relevantes articuladas aos seus aspectos jurídicos societários $^{4}$.

Inicialmente, destaca-se que, em decorrência dos estudos sobre a separação entre propriedade e controle ${ }^{5}$, em especial teorias econômicas sobre a empresa, uma nova questão ganhou relevância: o alinhamento entre os interesses dos detentores do poder e dos titulares da propriedade da sociedade. Na medida em que cresce o poder dos administradores, também aumenta a dificuldade de controlar seus atos e de verificar se de fato atuam no melhor interesse e benefício da sociedade.

\footnotetext{
3 Portanto, destaca-se que o presente trabalho não tem como pretensão exaurir o estudo dos planos de opção de compra de ações, que é amplo e inclui a análise de outros campos do direito que não somente o societário.

4 Destaca Egberto Lacerda Teixeira que: “O instituto em exame apresenta inegavelmente aspectos interessantes na prática das sociedades, constituindo mecanismo bastante útil, destinado a remunerar e incentivar todos aqueles que prestam efetivos serviços à companhia. A experiência no exterior atesta sua importância e utilidade”. TEIXEIRA, Egberto Lacerda; GUERREIRO, José Alexandre Tavares. Das sociedades anônimas no direito brasileiro. v. 1. São Paulo: Bushatsky, 1979. p. 332.

5 Sobretudo após a crise de 1929 nos Estados Unidos, diversos trabalhos sobre a estrutura da sociedade foram elaborados, com destaque à obra "The Modern Corporate and Private Property" de Adolph A. Berle e Gardiner Means. Referidos autores descreveram os diversos níveis de separação entre a propriedade de uma sociedade e o seu controle, de modo que com a crescente dispersão das ações entre inúmeros acionistas, o controle da sociedade também gradativamente se deslocava para as mãos de seus administradores.
} 
Nesse sentido, a chamada governança corporativa é tema de fundamental importância para a compreensão da forma de organização e controle do exercício desse poder, surgindo como uma forma de direcionamento de condutas e alinhamento dos interesses das mais diversas partes envolvidas nas sociedades. Inserida no contexto do direito societário motivo da limitação do escopo deste trabalho -, a governança corporativa passou a ser amplamente discutida e analisada justamente por abranger questões atinentes à separação de poderes entre acionistas e administradores. Relaciona-se à ideia de gestão proba, transparente e com respeito aos interessados na sociedade (compatibilizando os seus diversos interesses), não se confundindo, embora por vezes se relacione, com ferramentas gerenciais e com a responsabilidade social da companhia. Permite, assim, a governança corporativa, sem prejuízo do interesse social, a ampla fiscalização e a divulgação de informações ao mercado ${ }^{6}$.

Nesse contexto, deve-se destacar que o bem-estar de uma parte pode ser afetado negativamente pela ação de outra parte. Assim, o desafio do chamado conflito de agência consiste na motivação do agente em atuar no melhor interesse do principal, e não simplesmente conforme seus próprios interesses, como no caso, por exemplo, do alinhamento dos interesses de acionistas (principais) e administradores detentores do poder em companhias de capital pulverizado (agentes). A fim de mitigar a ocorrência desses conflitos, o principal deve arcar com determinados custos (os chamados custos de agência), que incluem custos de monitoramento e de incentivo, os quais serão analisados adiante no presente trabalho. Por ora, destaca-se dentre esses custos a aprovação de planos de opção de compra de ações como forma de alinhamento de interesses e consequente redução dos custos de agência ${ }^{7}$.

Todavia, ressalta-se que atualmente a pulverização do capital de uma sociedade não é pressuposto para que se aprove um plano de opção de ações, conforme acima exemplificado. Tenha a sociedade um acionista controlador, tenha ela o seu controle disperso, em regra, os planos de opção de ações têm como objetivo o devido alinhamento de interesses entre as diversas partes envolvidas. Porém, um esforço evolutivo em relação às causas que deram

\footnotetext{
6 Cf. RIBEIRO, Milton Nassau. Aspectos Jurídicos da Governança Corporativa. São Paulo: Quartier Latin, 2007. p. 23 e 24.

Adriana Josuá, por exemplo, explica que "nos sistemas em que o capital acionário é pulverizado (tipicamente Estados Unidos e Inglaterra), os custos de incentivos (bonding costs) nas companhias abertas são aqueles incorridos pelos acionistas (indiretamente, através da companhia) para incentivar a atuação dos administradores e alinhar os interesses destes com os seus. É comum, nestes casos, a utilização de planos de opção de compra de ações e pagamento de bônus à administração conforme a performance da companhia”. JOSUÁ, Adriana. Governança Corporativa e Teoria da Agência. São Paulo, 2005. 176 f. Dissertação (Mestrado). Faculdade de Direito, Universidade de São Paulo. p. 21.
} 
origem ao instituto é fundamental para a compreensão do mesmo, razão pela qual a estrutura da propriedade da sociedade será utilizada como ponto de partida deste estudo.

Não obstante a importância do tema, não se pretende aprofundar o estudo das opções por si só consideradas, isto é, fora do contexto de um plano de opções. À guisa de esclarecimento, ensina José Alexandre Tavares Guerreiro ${ }^{8}$, que são três as espécies envolvendo opções de ações de sociedades por ações: (i) as opções outorgadas nos termos do artigo 168, § $3^{\circ}$, da Lei das Sociedades por Ações; (ii) as opções negociadas em Bolsas de Valores; e (iii) as opções contratadas por titulares de ações. Como já destacado, será justamente o primeiro caso o objeto da presente dissertação. Não farão parte do tema principal deste trabalho, portanto, as demais espécies, bem como cláusulas ou pactos de opção envolvendo ações no contexto de outros negócios.

A título meramente ilustrativo ${ }^{9}$, quanto às origens dos contratos de opção, destaca-se o fenômeno ocorrido na Holanda no século XVII, conhecido como “Tulipomania”10. Trata-se de uma corrida por tulipas como forma de demonstração de riquezas e poder. No entanto, a crescente demanda, assim como a possibilidade de aumentar os ganhos com este mercado, fez crescer a especulação. Assim, foram criados contratos futuros, muitas vezes associados a contratos de opção, que permitiam, a partir de uma pequena soma, a aquisição de tulipas de uma plantação futura. Nas palavras de Christian C. Day:

\begin{abstract}
There was indeed speculation in bulbs; a tulip bulb futures market developed to fund the horticulture. By the 1620s the tulip had become the flower of fashion. A futures market for tulips gradually emerged for professional horticulturists and speculators. Buying in the winter for future delivery came into practice around 1634, that is, contracts for future delivery were made during the fall and winter. Like present day futures markets, these options, or futures, only required a small percentage of the purchase price for the option. But there were substantial and consequential differences as will be seen ${ }^{11}$.
\end{abstract}

\footnotetext{
8 Nos termos do parecer datado de 9 de dezembro de 2002, constante do Processo CVM n ${ }^{\circ}$ SP 2002/0474 (RC no 3948/2002), disponível em: <http://www.cvm.gov.br/>. Acesso em: 11 maio 2011.

9 Por fugir ao tema, não se avançará no estudo histórico das opções, o que, obviamente, demandaria um trabalho à parte. São apresentadas, apenas, algumas referências históricas que demonstram a importância do instituto.

10 Casos anteriores à chamada Tulipomania podem ser identificados. Felipe Campana Padin Iglesias, como exemplo, cita (i) a história bíblica de Jacó e Labão, na qual o último concede ao primeiro o direito de poder de casar com sua filha; (ii) os escritos antigos quando tratam do caso do filósofo de Tales de Mileto, que teria contrato opções de uso de prensas prevendo colheitas fartas a partir de seus conhecimentos astronômicos; bem como (iii) a utilização de opções em negócios marítimos pelos fenícios e, posteriormente, pelos portugueses. A Tulipomania, no entanto, foi a ocasião de maior destaque. Cf. IGLESIAS, Felipe Campana Padin. Opção de compra ou venda de ações no direito brasileiro: natureza jurídica e tutela executiva judicial. São Paulo, 2011. 329 f. Dissertação (Mestrado). Faculdade de Direito, Universidade de São Paulo. p. 17.

11 Tradução livre: "Na verdade houve especulação em bulbos; um mercado de futuros de bulbo de tulipa desenvolvido para financiar a horticultura. Na década de 1620, a tulipa se tornou a flor da moda. Um mercado de
} 
A "febre" das tulipas passou por um desaquecimento e, em 1637, as cotações sofreram uma grave depreciação, "quebrando” o sistema ${ }^{12}$. $\mathrm{Na}$ prática, a chamada Tulipomania acabou por disseminar a utilização dos contratos futuros e dos contratos de opção, influenciando o controle de riscos e o acesso aos mercados por pessoas com poucos recursos ${ }^{13}$.

No Brasil, a discussão dos problemas relacionados ao alinhamento dos interesses dos administradores e empregados aos da companhia e acionistas, sobretudo em razão da utilização de planos de opção de compra de ações, ainda é tímida. O tema ganhou destaque, sobretudo, com o recente crescimento econômico nacional que, nos últimos anos, passou a receber montantes cada vez maiores de investimentos estrangeiros. Com o aumento do aporte de capitais estrangeiros, também cresceu o número de sociedades que importaram a sistemática de trabalho e organização empresarial de suas matrizes, incluindo a adoção de programas de opção de compra de ações, tornando-as mais atrativas no mercado para seus trabalhadores atuais e futuros ${ }^{14}$.

Com efeito, os programas de stock option, inspirados sobretudo no direito norteamericano, se multiplicaram nas sociedades nacionais, implantando-se no Brasil, assim, a cultura de se repartir não somente o lucro, mas também, o êxito e o risco da atividade econômica exercida ${ }^{15}$. No entanto, apesar de sua crescente importância no cotidiano das sociedades brasileiras ${ }^{16}$, diferentemente do que se verifica em outros ordenamentos, não existe

futuros para tulipas emergiu gradualmente para os especuladores e horticultores profissionais. A compra no inverno para entrega futura entrou em prática por volta de 1634, isto é, os contratos para entrega futura foram feitos durante o outono e inverno. Como os mercados futuros atuais, essas opções (ou futuros) requeriam apenas uma pequena porcentagem do preço de aquisição para a opção. Mas havia diferenças e consequências substanciais, como será visto”. DAY, Christian C. Is there a tulip in your future?: ruminations on tulip mania and the innovative dutch futures markets. Journal des Economistes et des Etudes Humaines, v. 14, n. 2, dez. 2004. Disponível em: <http://ssrn.com/abstract=946140>. Acesso em: 23 jul. 2012.

12 Cf. DAY, Christian C. Is there a tulip in your future?, p. 162.

13 Sobre o tema, cf. SOUZA JR., Francisco Satiro. Regime jurídico das opções negociadas em bolsas de valores. São Paulo, 2002. 185 f. Tese (Doutorado em Direito). Faculdade de Direito, Universidade de São Paulo; e IGLESIAS, Felipe Campana Padin. Opção de compra ou venda de ações no direito brasileiro. 2011.

14 Nesse sentido, Almir Rogério Gonçalves afirma que na "história recente das transferências de investimentos tem sido muito comum que empresas multinacionais de grande porte ao se instalarem no Brasil decidam manter um programa de participação dos seus funcionários de primeiro escalão no lucro de suas empresas. Estes programas são realizados principalmente com o intuito de manter os benefícios que os funcionários, que estão se transferindo para o Brasil, possuíam quando eram funcionários da matriz da empresa. Com o tempo, e o desenvolvimento da empresa nacional, esta passa a ter a intenção de conceder estes benefícios não somente aos funcionários estrangeiros, como também aos seus novos gerentes contratados no país”. GONÇALVES, Almir Rogério. O sistema cambial brasileiro e a implantação de programas de stock options. Revista de Direito Mercantil, Industrial, Econômico e Financeiro. São Paulo, v. 119, p. 142-154, jul./set. 2000. p. 142.

15 Cf. CATÃO, Marcos André Vinhas. Tributação de Stock Options. Revista Dialética de Direito Tributário, v. 127, abr. 2006. p. 57.

16 No Brasil, os primeiros planos de opção de compra de ações de que se tem notícia datam da década de 1980 . No entanto, a expansão da utilização do instituto, de fato, ocorreu somente após a criação pela BM\&FBovespa 
no país vasta produção doutrinária, jurisprudencial ou legislativa sobre a matéria. Em função das diferenças e peculiaridades do ordenamento jurídico brasileiro, é importante compreender em que medida os exemplos estrangeiros são - ou podem ser - incorporados ao sistema brasileiro.

Portanto, a ideia da evolução da problemática dos planos de opção de ações será analisada em decorrência da grande utilização do instituto, tendo em vista seus princípios norteadores e práticas usuais de mercado. O estudo foi desenvolvido, porém, sempre evidenciando as articulações entre essa questão e o contexto social, com atenção às melhores práticas de governança corporativa.

Assim, foi realizada uma pesquisa detalhada dos planos em vigor disponíveis ao público, por meio de consultas a websites de companhias listadas no Novo Mercado, segmento de listagem diferenciado da BM\&FBovespa, o que se mostrou imprescindível para a compreensão prática do tema da presente dissertação. Essa consulta tornou possível um exame bastante próximo da realidade factual das sociedades brasileiras e viabilizou uma análise crítica dos principais parâmetros identificadores dos planos de opção de compra de ações brasileiros ${ }^{17}$.

Dessa forma, a presente exposição está organizada em duas partes. Na Parte I são explorados os principais conceitos e fundamentos relacionados ao tema dos planos de opção de compra de ações, analisando-se as principais instituições que os integram. Em seguida, na Parte II, são analisadas as normas aplicáveis, bem como as principais características das cláusulas dos planos usualmente adotadas pelas companhias abertas brasileiras.

de seus níveis diferenciados de listagem de ações, sobretudo o Novo Mercado. Cf. ARAGÃO, Paulo Cezar; SOARES, Daniela. Opções de Compra de Ações: uma análise da evolução do instituto no Brasil. In: CASTRO, Rodrigo R. Monteiro de (Coord.). Poder de Controle e Outros Temas de Direito Societário e Mercado de capitais. São Paulo: Quartier Latin, 2010. p. 158.

${ }_{17}$ Para uma lista detalhada das companhias consultadas, cf. anexo. 


\section{PRIMEIRA PARTE - CONCEITOS E FUNDAMENTOS}

Antes de tratar especificamente dos planos de opção de compra de ações, nesta primeira parte do trabalho pretende-se apresentar os principais fundamentos e conceitos necessários para a perfeita compreensão do tema.

Os planos de opção são utilizados primordialmente para atração e retenção de profissionais qualificados. Quanto mais atrativa for a remuneração, maior é a probabilidade de um determinado profissional permanecer na sociedade e, consequentemente, dedicar-se às suas atividades. Uma empresa que não valoriza e não estimula seus empregados enfrenta maior risco de perder seus funcionários para sociedades concorrentes. Assim, uma remuneração apropriada tende a alinhar os interesses dos empregados aos da companhia e de seus acionistas, mitigando os chamados conflitos de agência.

Nesta primeira parte do trabalho, serão analisadas as principais teorias acerca da evolução da teoria de agência, tomando como ponto de partida a estrutura da sociedade e as correntes doutrinárias relacionadas. Será realizado ainda um estudo dos principais aspectos dos deveres dos administradores, sobretudo aqueles deveres fiduciários que por vezes se relacionam à teoria da agência e norteiam o comportamento dos administradores e seu relacionamento com a companhia.

Por fim, tendo em vista a regulação dos planos de opção de compra de ações no ordenamento brasileiro, os principais aspectos do capital autorizado também serão destacados a fim de abranger todas as bases para o estudo do tema central da presente dissertação. 


\section{PANORAMA SOCIETÁRIO E GOVERNANÇA CORPORATIVA}

\subsection{INTRODUÇÃo}

A tese de Berle e Means, referente à questão da propriedade versus controle da sociedade anônima é atualmente considerada um marco no estudo do direito societário ${ }^{18}$. Foi estudada por diversos juristas e um de seus pontos controversos é justamente a questão de como o direito deve tratar o tema ${ }^{19}$. O trabalho conjunto e interdisciplinar envolvendo direito e economia, desenvolvido pelo advogado Adolf Berle e pelo economista Gardiner Means, acabou por incentivar diversas novas discussões, com destaque para três diferentes teorias ${ }^{20}$ : (i) a regulatória (regulatory approach); (ii) a administrativa (management approach); e (iii) a econômica (law and economics approach).

A regulatory approach é considerada a mais tradicional por ser a mais próxima das ideias centrais da obra de Berle e Means. Segundo essa teoria, é necessária uma regulação estatal da relação entre acionistas e administradores, visto que se entende que os administradores tendem a se aproveitar de sua posição para auferir alguma forma de vantagem sobre os acionistas. Assim, essa abordagem defende uma forte proteção legal, bem como uma maior presença estatal na regulação da relação entre acionistas e administradores. Segundo essa abordagem, que leva em conta o contexto norte-americano, certas regras societárias devem ser cogentes para assegurar padrões mínimos de proteção aos acionistas, tendo em vista as falhas do mercado e a passividade dos acionistas ao agirem coletivamente.

A management approach, por sua vez, aborda o tema sob o enfoque das atividades dos administradores. Nesse modelo, é presumido que os administradores protegerão os interesses dos acionistas porque, assim como estes, possuem interesse em proteger a sociedade. Apesar de, em regra, não possuírem grande quantidade de ações, seu sucesso (sua

18 Cf. BERLE JR., Adolf A.; MEANS, Gardiner C. The Modern Corporation \& Private Property. New York: Macmillan, 1933.

19 O presente tópico não tem a pretensão de apresentar detalhadamente as teorias relacionadas, a história ou o surgimento dos planos de opção de compra de ações em direito comparado ou nacional; propõe-se, simplesmente, a trazer algumas referências que parecem úteis para a contextualização do instituto.

20 A classificação é sugerida por Arthur R. Pinto e Douglas M. Branson. Cf. PINTO, Arthur R.; BRANSON, Douglas M. Understanding Corporate Law. ${ }^{\text {nd }}$ ed. San Francisco: Offices, 2004. p. 101 e 102. 
maior remuneração) depende do bom desempenho da sociedade, que disso decorre a confluência de interesses entre acionistas e administradores.

Por fim, Arthur R. Pinto e Douglas M. Branson afirmam que a law and economics approach tem sido a teoria dominante nas últimas décadas. Essa abordagem entende a separação entre propriedade e controle como benéfica, pois os acionistas investidores disponibilizam capital tendo como contrapartida a maximização dos lucros da companhia proporcionada pelos administradores. Sob essa perspectiva, eventual abuso pelos administradores é controlado internamente com base em soluções de mercado, em oposição à regulação estatal ${ }^{21}$.

Ressalta-se, ainda, que, justamente a partir da ideia central da obra de Berle e Means - ou seja, a propriedade versus o controle -, o tema da teoria da agência ganhou destaque ${ }^{22}$. No entanto, no âmbito da law and economics approach acima mencionada, deve-se destacar que o desenvolvimento de tal teoria da agência também é atribuído ao estudo das teorias da empresa $^{23}$, com destaque para o trabalho de Ronald Coase em The Nature of the Firm ${ }^{24}$. A partir da ideia de custos de transação, Coase concebeu a empresa como um feixe de contratos por meio dos quais se organizam a produção e a distribuição de bens no mercado. Neste feixe de contratos seria possível ainda incluir as relações de agência. Nesse sentido, a evolução da teoria da agência, como decorrência dos estudos econômicos da empresa, caracterizaria a figura do empresário administrador como a do agent, enquanto que aqueles que contribuíram para a organização da empresa seriam os principals.

Robert H. Sitkoff, por sua vez, destaca que três importantes correntes desenvolvidas a partir dos trabalhos de Coase devem ser mencionadas ${ }^{25}$ : (i) agency costs theory of the firm; (ii) property rights theories of the firm; e (iii) transacion costs theories. As transacion costs

\footnotetext{
21 Em trabalho sobre direito societário e desenvolvimento do mercado de capitais, Érica Cristina Rocha Gorga estuda o desenvolvimento da análise da Law \& Economics. Aponta algumas vertentes metodológicas do estudo da inter-relação entre os fenômenos econômico e jurídico, como os estudos realizados na Escola de Chicago, da Public Choice Theory, da Escola de New Haven, da Institutional e New Institutional Law and Economics. Para detalhes do referido estudo, cf. GORGA, Érica Cristina Rocha. Direito Societário Brasileiro e Desenvolvimento do Mercado de Capitais: uma perspectiva de "Direito e Economia". 2005.

22 A origem, contudo, da teoria da agência costuma ser atribuída à relação entre trustees e beneficiários de trusts.

${ }^{23}$ Segundo Stephen M. Bainbridge, a teoria da empresa é a subespécie da law and economics mais relevante para os estudos de direito societário. Tradução livre de "The theory of the firm is the sub-branch of law and economics most directly relevant to courses in corporate law". BAINBRIDGE, Stephen M. Corporation Law and Economics. Nova Iorque: Foundation, 2002. p. 26.

${ }^{24}$ Cf. COASE, Ronald H. The nature of the firm: the firm, the market and the law. Chicago; London: University of Chicago, 1990.

25 SITKOFF, Robert H. An Agency Costs Theory of Trust Law. Cornell Law Review, v. 89, p. 621-84, 2004. Disponível em: <http://papers.ssrn.com/abstract=412592>. Acesso em 16 jan. 2012. p. 634 e 635.
} 
theories baseiam-se fundamentalmente nas noções de custos de transação para analisar a empresa e a sua relação com o mercado. Por consequência, é a mais próxima da teoria original de Coase, uma vez que baseia-se na ideia de que a empresa pode ser vista como um feixe de contratos $^{26-27}$. Já as property rights theories of the firm basicamente tratam dos direitos de natureza patrimonial ${ }^{28}$. Por fim, as agency costs theory of the firm objetivam estabelecer, a partir do conceito de empresa proposto por Coase, os problemas da relação da agência sob a perspectiva de um feixe de contratos ${ }^{29}$.

Ainda em relação às teorias contratualistas de custos de agência, desenvolvidas, sobretudo, a partir dos anos 1970, cabe destacar que estas talvez tenham sido as principais teorias desenvolvidas em contraposição às ideias de Berle e Means. Segundo elas, a questão da separação entre propriedade e controle tão tratada por Berle e Means consistiria apenas em mais um custo de transação entre os diversos outros existentes no feixe de contratos que seria a empresa $^{30}$. Esse modelo, contudo, não prosperou. Willian W. Bratton explica que já nos anos 1990 a teoria se mostrou incapaz de solucionar certas questões envolvendo grandes companhias e os custos de agência permaneceram elevados. Em suma, Bratton conclui que a causa dessas questões é justamente o problema da separação entre propriedade e controle apontado por Berle e Means ${ }^{31}$.

\footnotetext{
26 Sobre o tema, cf. EASTERBROOK, Frank H.; FISCHEL, Daniel R. The Economic Structure of Corporate Law. Cambridge: Harvard University, 1991.

${ }^{27}$ Críticas às "nexus of contracts theories" podem ser observadas em: BRATTON, Willian W. The "Nexus of Contracts Corporation": A Critical Appraisal. Cornell Law Review, v. 74, p. 407-465, 1989.

28 Sobre o tema, vide também HART, Oliver; HOLMSTROM, Bengt. A theory of Firm Scope. Massachusetts Institute of Technology, Department of Economics Working Paper, n. 02-42, nov. 2002. Disponível em: $<$ http://papers.ssrn.com/abstract_id=355860>. Acesso em: 10 jan. 2012.

29 Sobre o tema, cf. JENSEN, Michael; MECKLING, William. Theory of the firm: managerial behavior, agency costs and ownership structure. Journal of Financial Economics, v. 3, n. 4, p. 305-360, out. 1976. Disponível em: <http://papers.ssrn.com/abstract=94043>. Acesso em: 15 abr. 2008. p. 05.

${ }^{30}$ Nesse contexto, Willian W. Bratton explica que "[u]nder the model there is no meaningful separation of ownership and control. Since the firm represents a series of contracts joining inputs to outputs, ownership becomes an irrelevant concept. Equity capital, the focus of the Berle and Means analysis, is simply one of the inputs and corporate law a part of that input's governing contract. Nor do the terms of the equity contract present problems calling for regulatory solution. The imperfections subsumed under Berle and Means' 'separation' rubric reemerge under the more neutral denomination 'agency costs'. In the model's pure version, free market competition solves the problem of the separation of ownership and control by forcing firms to minimize agency costs. Managers are not the powerful actors described by Berle and Means. When they fail, they get removedeither a hostile offer or takes over the company and throws them out, the firm with a high agency cost base fails to survive in the product market, or the managers fail to survive in the management labor market in the first place”. BRATTON, Willian W. Berle and Means Reconsidered at the Century's Turn. Journal of Corporation Law, v. 26, n. 3, 2001, p. 21. Disponível em: <http://papers.ssrn.com/paper.taf?abstract_id=255999>. Acesso em: 28 fev. 2012.

31 Cf. BRATTON, Willian W. Berle and Means Reconsidered at the Century's Turn, p. 22.
} 
Em consequência, foram desenvolvidas as teorias dos contratos incompletos. Sob essa perspectiva, a ideia do controle volta ao centro das discussões ${ }^{32}$. Segundo Bratton, certas formas de alocação de poder funcionam melhor que outras, pelo que a teoria busca identificar as características das melhores opções. Fundamentalmente, a teoria dos contratos incompletos concentra-se na compatibilidade de incentivos, distinguindo estruturas que permitem o melhor resultado (output) da empresa daquelas que não o fazem; ou seja, é possível afirmar que os precursores da teoria são Berle e Means, visto que foram eles os primeiros a expor o problema do alinhamento de interesses.

Assim, após examinar diversas correntes doutrinárias desenvolvidas ao longo do último século, Willian W. Bratton conclui que a análise realizada por Berle e Means antecipou as principais questões atualmente tratadas pelo direito societário. Nesse sentido, o referido autor justifica sua conclusão em quatro resumidos pontos:

\begin{abstract}
With this analysis Berle and Means anticipated the leading policy concerns of contemporary corporate legal theory. First, as they suggested, high salaries alone do not provide optimal motivation in the absence of stock ownership. Today's discussion turns to stock option compensation as an amelioration. But an optimal incentive package has yet to appear. Secondly, as they suggested, empire building is highly likely to show up in the system. (...). Thirdly, as they suggested, management and internally-influential nonshareholder constituents often have common interests contrary to those of the shareholders. (...). Finally, it is noted that Berle and Means did not model the separation of ownership and control as a monolithic phenomenon ${ }^{33}$.
\end{abstract}

Por fim, cabe destacar também que Berle e Means defendiam a necessidade de maior intervenção pública nas relações societárias internas das sociedades. Com base na jurisprudência (vinculante nos sistemas da common law) sobre os deveres fiduciários dos trustees, os referidos autores equiparavam as responsabilidades destes às dos agentes -

32 Nesse sentido, "[p]ower, expunged from the economic description of the firm by contractarianism, returns to the center of the picture under this theory. To the extent that advance contractual specification is not feasible, power allocations play a larger governance role and bear importantly on the firm's productivity”. Tradução livre: "poder, afastado da descrição econômica da empresa pelos contratualistas, retorna para o ponto central sob esta teoria. Na medida em que aprofundado detalhamento contratual não é viável, alocações de poder desempenham um papel importante em termos de governança e produtividade na empresa”. BRATTON, Willian W. Berle and Means Reconsidered at the Century’s Turn, p. 24.

33 Tradução livre: “Com esta análise, Berle e Means anteciparam os principais assuntos da teoria jurídica corporativa contemporânea. Primeiramente, como sugeriram, salários elevados por si só não fornecem motivação ideal na ausência de controle. A discussão atual desloca-se para a compensação com opções de ações como forma de melhoria. Mas um pacote de incentivo ideal ainda tem que surgir. Em segundo lugar, como sugeriram, é altamente provável que aparecem no sistema empire building. (...) Em terceiro lugar, como sugeriram, administradores e outras partes não acionistas (mas com influência interna na companhia) muitas vezes têm interesses comuns contrários dos acionistas. (...). Finalmente, note-se que Berle e Means não sugeriram a separação de propriedade e controle como um fenômeno estanque”. BRATTON, Willian W. Berle and Means Reconsidered at the Century's Turn, p. 26. 
denominação posteriormente atribuída em decorrência da separação entre propriedade e controle -, tendo em vista que o administrador (agente) de fato exercia os poderes relacionados à “propriedade da empresa”, originalmente detidos pelos principals (equiparados aos fiduciantes) ${ }^{34}$. A associação não prosperou na doutrina e na jurisprudência: ainda que na prática seja possível fazer uma aproximação, a contextualização teórica repele a ideia proposta por Berle e Means ${ }^{35}$. Não obstante, essa semelhança entre a relação da agência e a relação fiduciária causou a atribuição de deveres fiduciários (fiduciary duties) aos administradores, notadamente o dever de diligência, o dever de lealdade e o dever de informar.

Dessa forma, tendo em vista o escopo da presente dissertação, serão discutidos a seguir somente os aspectos jurídicos dos temas acima mencionados. A despeito das críticas aos estudos de Berle e Means e por mais que o desenvolvimento da teoria da agência possa também ser atribuído a outras teorias (econômicas), é evidente a relevância da obra de tais autores ${ }^{36}$ para o direito societário, o que justifica tomá-la como ponto de partida deste estudo, para, então, tratar-se dos temas originados remotamente a partir da relação entre trustees e beneficiários em um trust, em especial a teoria da agência e os deveres dos administradores. Sem prejuízo e por fim, serão abordadas as principais características do capital autorizado, relevante para a sistemática dos planos de opção de compra de ações no Brasil.

\subsection{Estrutura de Propriedade da Sociedade}

A mais clássica classificação dos “tipos” de controle é aquela sugerida por Berle e Means, segundo a qual quanto maior o grau de dispersão das ações de uma companhia, maior é o grau de dissociação entre propriedade e controle ${ }^{37}$. Segundo os referidos autores, mesmo com uma participação ínfima no capital social, administradores e determinados acionistas

\footnotetext{
34 Cf. JOSUÁ, Adriana. Governança Corporativa e Teoria da Agência, p. 86-88.

35 Conforme abaixo mencionado, a analogia é imperfeita. Primeiramente em razão do fato de que os administradores não são titulares dos bens sociais, diferentemente, portanto, do que ocorre com os trustees em relação aos bens do trust. Em segundo lugar, pelo fato de que a função do administrador é a de fazer os bens da companhia gerarem riquezas, e não de simplesmente conservá-los.

36 William W. Bratton afirma que o "Westlaw's 'JLR' index shows citations of The Modern Corporation and Private Property in 631 articles through the end of 1992, 42 of those articles published in 1999 itself”. BRATTON, Willian W. Berle and Means Reconsidered at the Century’s Turn, p. 2.

37 Sobre o tema, cf. BERLE JR., Adolf A.; MEANS, Gardiner C. The Modern Corporation \& Private Property, 1933.
} 
teriam poderes e autonomia suficientes para controlar a sociedade como um todo, assim como os bens indiretamente pertencentes aos demais acionistas ${ }^{38}$.

Ressalvado o fato de ser muito difícil separar por completo os diferentes tipos de controle, sendo que uma categoria não necessariamente exclui as outras ${ }^{39}$, a classificação de Berle e Means propõe cinco diferentes categorias ${ }^{40}$ : (i) controle quase totalitário; (ii) controle majoritário; (iii) controle por meio de artifícios legais; (iv) controle minoritário; e (v) controle gerencial. A despeito de quaisquer críticas que possam ser formuladas a essa classificação ${ }^{41}$, apresentam-se resumidamente as principais características de cada um dos tipos sugeridos.

O primeiro tipo - o controle quase totalitário - pode ser caracterizado como aquele em que tanto a propriedade da sociedade como o seu controle estão concentrados na mesma pessoa ou pequeno grupo organizado. Nesse cenário, não há que se falar em um controle exercido por pessoas com interesses conflitantes aos dos acionistas, pois trata-se das mesmas pessoas $^{42}$.

Caminhando pela gradativa escala de separação de propriedade e controle, o próximo tipo sugerido é o do controle majoritário, relacionado à propriedade da maioria das ações representativas do capital social de uma determinada sociedade. Não obstante o fato de que, na prática, o acionista detentor da maioria das ações é aquele que acaba por controlar a companhia, por vezes este pode vir a enfrentar uma minoria hostil e organizada que questione suas resoluções em assembleias gerais ou até mesmo em âmbito judicial ${ }^{43}$.

38 Erik Frederico Oiolo, nesse sentido, afirma que tais administradores e acionistas teriam "poderes de dispor sobre toda a organização empresarial, que pertence, de forma imediata, à pessoa jurídica que suporta a sociedade, e sobre a qual indiretamente têm direitos todos os demais acionistas”. OIOLI, Erik Frederico. Oferta Pública de Aquisição do Controle de Companhias Abertas. São Paulo, 2008. 202 f. Dissertação (Mestrado). Faculdade de Direito, Universidade de São Paulo. p. 16.

39 Cf. COMPARATO, Fábio Konder; SALOMÃO FILHO, Calixto. O Poder de Controle na Sociedade Anônima. 4. ed. Rio de Janeiro: Forense, 2005. p. 52.

40 BERLE JR., Adolf A.; MEANS, Gardiner C. The Modern Corporation \& Private Property, p. 70.

41 Como exemplos, é possível citar: Fábio Ulhôa Coelho, que excluiu a terceira modalidade (controle por meio de artifícios legais) (COELHO, Fábio Ulhôa. Curso de Direito Comercial. v. 2. 9. ed. São Paulo: Saraiva, 2006. p. 275); Rubens Requião, que excluiu o controle gerencial por considerar que tal modalidade se confunde com o controle minoritário (REQUIÃO, Rubens. Curso de Direito Comercial. v. 2. 24. ed. São Paulo: Saraiva, 2005. p. 144) e também Eduardo Secchi Munhoz, que não considera o controle gerencial uma forma de controle interno da companhia, mas sim uma espécie autônoma por não se basear em direitos de sócios (MUNHOZ, Eduardo Secchi. Empresa contemporânea e Direito Societário, Poder de Controle e Grupos de Sociedade. São Paulo: Juarez de Oliveira, 2002. p. 257).

42 Berle e Means explicam que "in such an enterprise, ownership and control are combined in the same hands". BERLE JR., Adolf A.; MEANS, Gardiner C. The Modern Corporation and Private Property. Nova Iorque: The Macmillan Company, 1933. p. 70.

43 Cf. GUIDUGLI, João Henrique. Controle Externo Contratual - O Desenvolvimento da Empresa e os Grupos de Contratos sob o Direito Societário. São Paulo: Quartier Latin, 2006. p. 38. 
O chamado controle obtido mediante expedientes legais (through a legal device), por sua vez, é aquele por meio do qual, sem a titularidade de ações representativas da maioria do capital social, determinados acionistas mantêm o controle da companhia pelo uso de dispositivos/artifícios legais ${ }^{44}$. Dentre os mecanismos abordados por Berle e Means são $\operatorname{citados}^{45}$ : (i) a estrutura piramidal; (ii) a existência de ações sem direito de voto (que poderia ser uma variação do mecanismo de emissão de ações com voto limitado); e (iii) o voting trust.

Já o controle minoritário é aquele segundo o qual um acionista ou um grupo de acionistas detém o controle da sociedade embora possua uma parcela inferior à maioria do capital social. Esse controle se dá em virtude, por exemplo, da grande abstenção dos acionistas nas assembleias gerais - quanto maior a dispersão do capital social de uma sociedade, maiores são as probabilidades de um acionista com uma pequena participação pensar que sua efetiva presença na assembleia geral não poderá alterar os rumos sociais; assim, tal acionista simplesmente não comparece às reuniões, uma vez que não tem incentivos para fazê-lo ${ }^{46}$. Ademais, Berle e Means explicam que esse tipo de controle minoritário também pode se dar por meio da outorga de procurações. Com a reunião de diversas participações minoritárias, um determinado grupo de acionistas consegue se organizar e garantir a maioria dos votos nas assembleias ${ }^{47}$.

Por fim, o quinto tipo de controle, o controle gerencial, caracteriza-se pela grande dispersão do capital social. Nesse caso, um único acionista ou grupo de acionistas não possui uma participação societária capaz de, isoladamente, controlar a sociedade ${ }^{48}$. Dessa forma, os próprios administradores da sociedade passam a exercer o seu controle ${ }^{49}$. Nota-se, portanto, que em razão da grande pulverização da propriedade acionária, o controle fica desvinculado da titularidade das ações e o alinhamento de interesses passa a ter extrema relevância.

\footnotetext{
44 "In the effort to maintain control of a corporation without ownership of a majority of its stocks, various legal devices have been developed”. BERLE JR., Adolf A.; MEANS, Gardiner C. The Modern Corporation and Private Property, p. 72.

45 Sobre o tema, cf. GUIDUGLI, João Henrique. Controle Externo Contratual, p. 38-40.

46 Para João Henrique Guidugli, "esses dois fatores mantêm uma relação diretamente proporcional, na medida em que, quanto maior o capital da sociedade e maior o número de acionistas, menor será a participação média de cada um deles frente à sociedade como um todo. Em consequência, menores serão os incentivos de qualquer acionista individualmente considerado para se informar e controlar os negócios sociais”. GUIDUGLI, João Henrique. Controle Externo Contratual, p. 41.

47 Segundo os referidos autores, um grupo de acionistas "is often said to have 'working control' of the company”. BERLE JR., Adolf A.; MEANS, Gardiner C. The Modern Corporation \& Private Property, p. 80.

48 Segundo Berle e Means, "[t]he fifth type of control is that in which ownership is so widely distributed that no individual or small group has even a minority interest large enough to dominate the affairs of the company". BERLE JR., Adolf A.; MEANS, Gardiner C. The Modern Corporation \& Private Property, p. 84.

49 Cf. GUIDUGLI, João Henrique. Controle Externo Contratual, p. 45.
} 
Entendidas as diferentes formas de exteriorização do controle, as práticas de governança corporativa surgem como uma forma de direcionamento de condutas e alinhamento dos interesses das mais diversas partes envolvidas nas companhias. Inserida nesse contexto, a teoria da agência se revela importante para o estudo dos planos de opção de compra como forma mitigadora de riscos. Antes, contudo, com o objetivo de melhor compreender o contexto do alinhamento de interesses, em torno do qual é constituído o presente trabalho, discorrer-se-á um pouco mais sobre a governança corporativa.

\subsection{GOVERNANÇA CORPORATIVA}

A chamada "governança corporativa" ${ }^{50}$ está relacionada às ideias de gestão proba, transparente e com respeito aos interessados na companhia (compatibilizando os seus diversos interesses), não se confundindo - embora por vezes se relacione - com ferramentas gerenciais e com a responsabilidade social da companhia ${ }^{51}$. A governança corporativa permite a ampla fiscalização e a divulgação de informações da companhia ao mercado ${ }^{52}$.

\footnotetext{
50 Diversas são as críticas na doutrina nacional em relação à tradução literal da expressão inglesa "corporate governance”. Ao analisar a utilização do termo em outros ordenamentos, Marcelo Vieira von Adamek destaca que "[n]a Alemanha, até mesmo o legislador adotou a expressão inglesa 'corporate governance', sem, no entanto, tentar traduzi-la (...). Na Itália, alude-se a 'governo dell'impresa' ou 'governo societário' (...). Na França, 'gouvernement des entreprises'. No Brasil, uma péssima tradução literal ( 'at the foot of the letter', como sói jocosamente dizer das más traduções literais) fez vingar a expressão 'governança corporativa', que, a rigor, é inexpressiva. 'Governança' é sinônimo de 'governo', quando não de 'intendência'. 'Corporativa' é o adjetivo utilizado para designar aquilo que é relativo às corporações, palavra essa que, juridicamente, tem sentido bastante diverso ( = agremiação ou união de pessoas, subordinadas e uma regra, estatuto ou compromisso) e que apenas por meio da tradução homófona do termo norte-americano 'corporation' estaria a designar as sociedades anônimas (lembre-se, a propósito, que, no direito inglês, a palavra 'corporation' não designa apenas as anônimas). Em Portugal, assim, alude-se, com maior propriedade, a 'corporate governance' ou 'governo das sociedades'”. ADAMEK, Marcelo Vieira von. Responsabilidade civil dos administradores de S/A/, p. 115.

51 Não se pretende no presente item realizar um estudo detalhado sobre a governança corporativa, o que demandaria trabalho específico. Assim, são apresentadas apenas breves referências e entendimentos sobre o tema, com o intuito de melhor contextualizar a relação entre os planos de opção de compra de ação e o alinhamento de interesses. Diversas são as obras que tratam da governança corporativa no Brasil. Como referência, cf.: JOSUÁ, Adriana. Governança Corporativa e Teoria da Agência, 2005; SANTOS, Aline de Menezes. Reflexões sobre a Governança Corporativa no Brasil. Revista de Direito Mercantil, Industrial, Econômico e Financeiro, n. 130, ano XLII (Nova Série) abr./jun. 2003; LAUTENSCHLEGER JÚNIOR, Nilson. Os desafios propostos pela Governança Corporativa ao direito empresarial brasileiro. São Paulo: Malheiros, 2005; ANDRADE, Adriana; ROSSETTI, José Paschoal. Governança Corporativa: fundamentos, desenvolvimento e tendências. São Paulo: Atlas, 2004; RIBEIRO, Milton Nassau. Aspectos Jurídicos da Governança Corporativa, 2007.

52 Cf. RIBEIRO, Milton Nassau. Aspectos Jurídicos da Governança Corporativa, p. 23 e 24.
} 
Não obstante haver grande debate doutrinário sobre a definição de um marco específico das discussões sobre a governança corporativa, Nilton Lautenschleger Júnior sustenta que o sistema jurídico norte-americano pode ter sido, sim, o ponto de partida do debate e que seu enfoque estaria marcado pela questão da relação entre investidores de capitais ou proprietários e administradores ${ }^{53}$, ou seja, a questão propriedade versus controle, mencionada anteriormente.

Da mesma forma, em trabalho sobre a formação e a evolução da governança corporativa $^{54}$, Voicu-Dan Dragomir - ao indicar dez pontos relevantes para o desenvolvimento governança corporativa ${ }^{55}$ - confirma a relevância dos conflitos de agência $^{56}$ ao incluir dentre referidos pontos não só a teoria da agência, mas também a evidência “pré-contemporânea” que foi o controle gerencial decorrente da separação da propriedade do controle, conforme trabalhos de Berle e Means.

Especificamente com relação a esta separação entre propriedade e controle da companhia, que pode ser considerada uma das origens dos conflitos de agência entre acionistas e administradores, Mark J. Roe ${ }^{57}$, em seus estudos sobre governança corporativa, sugeriu uma classificação que divide o instituto em dois sistemas: (i) o sistema de governança corporativa vertical e (ii) o sistema horizontal. Enquanto a dimensão horizontal da governança corporativa refere-se aos problemas de agência entre acionistas, o sistema vertical trata da oposição de interesses entre administradores e acionistas pouco participativos na gestão da sociedade. O foco da governança corporativa vertical, portanto, é

53 LAUTENSCHLEGER JÚNIOR, Nilson. Os desafios propostos pela Governança Corporativa ao direito empresarial brasileiro, p. 34.

54 DRAGOMIR, Voicu-Dan. Highlights for a History of Corporate Governance. European Journal of Management, 2008. Disponível em: <http://papers.ssrn.com/sol3/papers.cfm?abstract_id=1114045>. Acesso em: 05 set. 2012.

55 São eles: "the emergence of the corporation and the criticisms expressed by Adam Smith; the birth of the modern theory of corporate governance - Berle and Means (1932), Jensen and Meckling (1976) and Freeman (1984) - as proponents of agency theory, and skateholders theory, respectively; corporate governance codes and the European Union's policy concerning corporate governance; the Enron case and the fall of Arthur Andersen, followed by the controversy surrounding the Sarbanes-Oxley Act; finally, the globalization of corporate governance and the responsibility of the true and fair reporting as promoted by the OECD Principles of Corporate governance”. Tradução livre: “o surgimento da empresa e as críticas expressadas por Adam Smith; o nascimento da moderna teoria da governança corporativa - Berle e Means (1932), Jensen e Meckling (1976) e Freeman (1984) - como os precursores da teoria de agência e da teoria de skateholders, respectivamente; códigos de governança corporativa e política da União Europeia em matéria de governança corporativa; caso Enron e a queda de Arthur Andersen, seguida da controvérsia em torno da lei Sarbanes-Oxley; por fim, a globalização da governança corporativa e a responsabilidade quanto a divulgação correta e verdadeira, como preconizada pelos princípios de governança corporativa da OCDE”. DRAGOMIR, Voicu-Dan. Highlights for a History of Corporate Governance. p. 1.

56 Sobre o tema, cf.: SANTOS, Aline de Menezes. Reflexões sobre a Governança Corporativa no Brasil, p. 186.

57 ROE, Mark J. The Institutions of Corporate Governance. 01 ago. 2004. Harvard Law and Economics Discussion Paper, n. 488. Disponível em: <http://ssrn.com/abstract=612362>. Acesso em: 05 set. 2012. 
o controle/monitoramento dos conflitos de agência, de forma a manter os administradores leais aos interesses dos acionistas.

Com a criação em 2000 pela BM\&FBovespa de segmentos de negociação especial, consolidaram-se no país as práticas de governança corporativa e estabeleceu-se um ambiente favorável ao mercado secundário e à captação de recursos e investimentos. É sabido no mercado que as ações de uma companhia serão cada vez mais valorizadas e ganharão cada vez mais liquidez quanto maior for o grau de segurança proporcionado por seus acionistas e quanto mais informações forem prestadas ao mercado por seus administradores. A expansão e consolidação da governança corporativa não é benéfica somente para as empresas, mas também para todo o corpo acionário das companhias. A busca pelo tratamento igualitário permite até mesmo o questionamento do fundamento legal de determinadas normas, bem como da necessidade ou não de alterações legislativas. É possível citar dentre os princípios básicos que abrangem as boas práticas de governança corporativa ${ }^{58}$ : (i) Equidade (fairness); (ii) Cumprimento a Regras (compliance); (iii) Prestação de Contas (accountability); e (iv) Transparência (disclousure).

Destaca-se, ainda, que as boas práticas de governança corporativa no Brasil surgiram e ganharam destaque como forma de proteção não só de acionistas minoritários, mas também de stakeholders $^{59}$, abrindo espaço, portanto, para o desenvolvimento e a ampliação do mercado de capitais nacional, cenário sem o qual seria praticamente inviável a dispersão acionária, em virtude da grande insegurança e sujeição dos minoritários à discricionariedade do bloco controlador ${ }^{60}$.

Com base em estudos e avaliações empíricas que demonstram que os investidores estão dispostos a pagar mais pelas ações das companhias que adotam melhores práticas de governança corporativa e que apresentam maior grau de transparência ${ }^{61}$, as companhias que se enquadrarem às regras diferenciadas de governança poderão obter do mercado melhor precificação de suas ações, proporcionando, com isso, menores custos de captação. Por outro

\footnotetext{
58 Cf. ANDRADE, Adriana; ROSSETTI, José Paschoal. Governança Corporativa, p. 140 e 141.

59 Milton Nassau Ribeiro afirma que o termo "é utilizado para designar os demais interessados nas atividades da companhia, como empregados, fornecedores, clientes, comunidade e até mesmo cidadãos e governo. Stake quer dizer risco no jargão do mercado financeiro. Stakeholder refere-se àqueles que possuem o risco associado ao desempenho da empresa ao qual se relacionam”. RIBEIRO, Milton Nassau. Aspectos Jurídicos da Governança Corporativa, p. 24.

60 Ressalta-se que, conforme o parágrafo único do artigo 116 da Lei das Sociedades por Ações, o acionista controlador deve usar o seu poder de controle com o fim de fazer a companhia realizar o seu objetivo e cumprir a sua função social, e tem deveres e responsabilidades para com os demais acionistas da empresa, os que nela trabalham e para com a comunidade em que atua, cujos direitos e interesses deve lealmente respeitar e atender.

61 Disponível em: <http://www.bovespa.com.br/Principal.asp>. Acesso em: 03 maio 2008.
} 
lado, é uma oportunidade para os investidores adquirirem ações com direito a voto, garantindo-lhes uma presença mais significativa nos negócios sociais (como no caso das empresas listadas no Novo Mercado da BM\&FBovespa, que apenas admite a emissão de ações ordinárias).

Ressalta-se que a adesão de uma companhia a segmentos diferenciados de governança implica o dever de observar certas regras, que nada mais são do que práticas de governança corporativa, cujo escopo é o de ampliar e proteger os direitos de acionistas minoritários, bem como de garantir a divulgação de informações relevantes para a companhia, além das comumente exigidas em lei, assemelhando-se àqueles mercados mais desenvolvidos e já com grande liquidez dos títulos negociados.

Assim, caso a empresa listada nos níveis diferenciados descumpra alguma de suas regras, a BM\&FBovespa pode estabelecer multas, suspender a negociação de suas ações ou, nos casos mais graves, cancelar o registro da companhia. Tais sanções não decorrem de códigos de boas práticas (como o do IBGC que são meramente sugestivos e exemplificativos), mas sim do contrato de adesão firmado com a BM\&FBovespa por ocasião da adesão da companhia ao segmento diferenciado ${ }^{62}$.

Conforme o princípio geral de equidade, as regras de governança corporativa visam proteger os interesses de todos os acionistas, independentemente de qual espécie ou classe de ações tais acionistas sejam titulares, assim como de administradores, empregados e os da própria companhia. A vulnerabilidade dos acionistas existirá em relação aos administradores na medida em que estes gerenciam, por vezes sem controlar, a propriedade daqueles. Tal vulnerabilidade pode ser notada a partir da relação ou teoria da agência.

\subsubsection{RELAÇão de AgÊNCIA}

A chamada relação de agência ocorre quando um ou mais agentes, denominados “principais”, contratam outras pessoas, denominados “agentes” para realizarem certos trabalhos em seu nome. Ressalta-se que, para a realização de tal trabalho, o agente deve

\footnotetext{
62 Neste sentido, Eduardo Alfred Taleb Boulos e Fernando Szterling afirmam que "a imposição de sanções tem, assim, que se apoiar no fundamento contratual, encontrado nos contratos celebrados entre a Bovespa e os sujeitos dessa normativa, que caracteriza um contrato plurilateral normativo, ou mais especificamente, de organização". BOULOS, Eduardo Alfred Taleb; SZTERLING, Fernando. Novo Mercado e as práticas diferenciadas de governança corporativa: exame de legalidade referente aos poderes das bolsas de valores. Revista de Direito Mercantil, São Paulo: Malheiros, v. 125, p. 96-113, jan./mar. 2002. p. 113.
} 
previamente receber autoridade de tomada de decisões do principal, para que, em seu nome e interesse, possa agir. Em trabalho sobre comportamento administrativo e estruturas de propriedade, Michael C. Jensen e Willian H. Meckling definem a relação de agência da seguinte forma: "We define an agency relationship as a contract under which one or more persons (the principal(s)) engage another person (the agent) to perform some service on their behalf which involves delegating some decision making authority to the agent”63.

A grande questão da relação de agência é saber como sintonizar os interesses do principal com os do agente, isto é, como dirimir eventuais conflitos quando o agente passa a atuar de acordo com as suas próprias vontades, desconsiderando o melhor interesse do principal. Os chamados conflitos de agência, portanto, surgem sempre quando o bem-estar do principal passa a depender das ações a serem tomadas pelo agente. O problema reside em como incentivar o agente a agir no melhor interesse do principal, e não simplesmente em seus próprios $^{64}$.

Neste contexto, é possível identificar três tipos de conflitos de agência ${ }^{65}$ :

(i) o primeiro deles, facilmente verificado em companhias de capital pulverizado, envolve o conflito entre os proprietários da companhia e os administradores contratados. Neste caso, os primeiros são os principais e os últimos, os agentes. O conflito reside no fato de que os administradores são responsáveis e devem agir no interesse dos proprietários, e não nos seus próprios;

no segundo tipo de conflito estão, de um lado, os proprietários da maioria das ações representativas do capital social, e, de outro, os acionistas minoritários não controladores. Estes últimos, segundo a tipificação da relação de agência, seriam os principais, enquanto os primeiros seriam os agentes. Aqui o problema consiste no fato de os minoritários não serem expropriados pelos controladores; e

\footnotetext{
63 JENSEN, Michael; MECKLING, William. Theory of the firm, p. 05.

64 Segundo Henry Hansmann e Reinier Kraakman, “(...) 'agency problems' (...) arises whenever the welfare of one party, termed the 'principal', depends upon actions taken by another party, termed the 'agent'. The problem lies in motivating the agent to act in the principal's interest rather than simply in the agent's own interest". Tradução livre: “(...) os problemas de agência (...) surgem sempre quando o bem estar de uma parte, o chamado 'principal' depende das ações praticadas por uma outra parte, o chamado 'agente'. O problema reside na motivação do agente em agir tendo em vista os interesses do principal, e não em seus próprios”. HANSMANN, Henry; KRAAKMAN, Reinier. Agency Problems and Legal Strategies. Yale Law School, Center for Law, Economics and Public Policy Research Paper n. 301. Disponível em: <http://ssrn.com/abstract=616003>. Acesso em: 09 abr. 2008. p. 21.

65 Cf. HANSMANN, Henry; KRAAKMAN, Reinier. Agency Problems and Legal Strategies, p. 22.
} 
(iii) por fim, o último tipo de conflito identificável é aquele que envolve a companhia em si e terceiros com quem ela contrata, tais como credores, empregados e clientes. A dificuldade aqui está no fato de a companhia, como agente, não agir adequadamente frente aos vários terceiros (principais), por exemplo, expropriando credores, explorando trabalhadores ou enganando consumidores.

Diante das hipóteses expostas acima, nota-se que os planos de opção de compra podem atuar como uma forma de mitigação de conflitos de agência, sobretudo aqueles que envolvem acionistas e administradores (primeira das três hipóteses mencionadas).

Uma vez cientes desses problemas, ou da possibilidade de sua ocorrência, questionam-se os acionistas e a própria companhia sobre como minimizá-los ou evitá-los. Eugene F. Fama e Michael C. Jensen ${ }^{66}$, por exemplo, sustentam que as companhias devem controlar os conflitos de agência decorrentes da separação da propriedade do controle separando as chamadas decisões de administração das decisões de controle ${ }^{67}$. Defendem tais autores que melhores resultados podem ser alcançados em companhias complexas ${ }^{68}$ delegando-se as funções de decidir para agentes em todos os níveis da organização. Assim, o controle dos conflitos de agência é atingido na medida em que ocorre a separação entre decisões de controle e decisões de administração, ficando estas difundidas em todos os níveis de organização da companhia.

Henry Hansmann e Reinier Kraakman, por sua vez, apontam algumas estratégias jurídicas (legal strategies) como forma de mitigar a vulnerabilidade dos principais perante o oportunismo dos seus agentes. Dividem-nas em duas categorias: (i) estratégias regulatórias (regulatory strategies); e (ii) estratégias de governança (governance strategies). As primeiras são prescritivas e descrevem os termos que regularão tanto o contexto da relação entre principal e agente quanto sua formação e dissolução. As estratégias de governança, por sua vez, descrevem os elementos de hierarquia e dependência que comumente caracterizam as

66 Cf. FAMA, Eugene F.; JENSEN, Michael C. Separation of Ownership and Control. Journal of Law and Economics, v. XXVI, jun. 1983. Disponível em: <http://papers.ssrn.com/abstract=94034>. Acesso em: 09 set. 2012.

67 Em termos gerais, os autores explicam que o processo decisório em uma companhia divide-se em quatro etapas: (i) a iniciação, que são propostas para utilização dos recursos e estruturação dos contratos; (ii) a ratificação, que é a escolha das iniciativas de decisão a serem implementadas; (iii) a implementação, que é a execução das decisões ratificadas; e (iv) o monitoramento da performance dos agentes que tomam as decisões e da implementação das recompensas. Reúnem, assim, a iniciação e a implementação nas "decisões de administração” e a ratificação e o monitoramento nas “decisões de controle”.

68 Pode-se entender como uma "companhia complexa” aquela em que as informações relevantes para a tomada de decisões está difusa entre vários agentes. 
relações de agência; tendem a proteger indiretamente os principais, não só enfatizando seu poder, como também ajustando e adaptando os incentivos dados aos agentes ${ }^{69}$.

Independentemente da forma ou mecanismo de evitar ou mitigar os conflitos de agência, algum tipo de custo é gerado. Nesse sentido, Jensen e Meckling definem os chamados “custos de agências” como a soma dos gastos de monitoramento das atividades dos agentes (the monitoring expenditures by the principal), dos gastos incorridos pelo agente para demonstrar ao principal que seus atos não o prejudicarão, ou que, se isso acontecer, o principal será recompensado (the bonding expenditures by the agent), e das perdas residuais (the residual loss) causadas por eventuais divergências das decisões das partes ${ }^{70}$.

\subsubsection{Custos de Monitoramento (Monitoring Expenditures)}

Os custos de monitoramento são aqueles incorridos pelos principals para, como o próprio nome diz, monitorar ou supervisionar as atividades dos agents, de forma a assegurar que estes atuem no melhor interesse daqueles. Dentre os custos do referido monitoramento, é possível citar aqueles incorridos com a realização de auditorias, com as medidas necessárias para a devida prestação de contas e transparência e divulgação de informações relevantes ${ }^{71}$.

Destaca-se, ainda, que os custos de monitoramento podem ser verificados mesmo antes da contratação de determinado empregado ${ }^{72}$. Os custos incorridos com a análise e investigação do perfil do candidato podem também caracterizar custos de monitoramento, os quais, como dito, vão desde a seleção para contratação até o desligamento do administrador/empregado da companhia. O propósito, de forma geral, é sempre o de mitigar o risco da prática pelos agents de atos praticados com desvio de poder ou até mesmo fraudulentos.

\subsubsection{Custos de Incentivo (Bonding Expeditures)}

A simples supervisão pelo principal, contudo, nem sempre é suficiente para garantir a atuação, pelo agent, em benefício do principal e da forma por ele desejada. Para garantir

69 HANSMANN, Henry; KRAAKMAN, Reinier. Agency Problems and Legal Strategies, p. 23.

70 Cf. JENSEN, Michael; MECKLING, William. Theory of the firm, p. 05 e 06.

71 Cf. JOSUÁ, Adriana. Governança Corporativa e Teoria da Agência, p. 20.

72 Cf. PINTO, Arthur R.; BRANSON, Douglas M. Understanding Corporate Law, p. 102. 
que os resultados da companhia sejam os melhores possíveis e que, de fato, maximizem os interesses dos principals, estes, além de monitorarem as atividades dos agents, também se valem de mecanismos de incentivo de desempenho, como, por exemplo, os planos de opção de compra de ações.

Adicionalmente, o principal poderá vir a pagar ao agente outros montantes equivalentes aos gastos que estes terão para garantir que não praticarão certos atos que podem vir a prejudicar o principal ou para garantir que o principal será compensado se o administrador tomar tais decisões. Arthur R. Pinto e Douglas M. Branson, por exemplo, explicam que o empregado pode vir a incorrer em certos custos na preparação de materiais a serem analisados durante o processo de seleção para contratação, tais como currículo e lista de atividades já exercidas, bem como pode concordar em realizar certos atos para se manter na posição $^{73}$.

\subsubsection{Perdas Residuais (Residual Loss)}

Por fim, inevitavelmente existirão outros custos a serem arcados pelos principals em razão da relação de agência. Mesmo considerando os custos de monitoramento e de incentivo, outras perdas podem ocorrer em razão de, por exemplo, divergências entre as decisões dos agents e aquelas que garantiriam aos principals maior retorno; ou, como exemplificam Arthur R. Pinto e Douglas M. Branson, caso um determinado empregado faça longos períodos de intervalo em sua jornada de trabalho ou use os recursos da companhia para fins pessoais, tais como a utilização de impressoras ou de telefone ${ }^{74}$.

Assim, os conflitos de agência tiveram grande influência no desenvolvimento de novos mecanismos de monitoramento e controle das atividades dos administradores das companhias por seus acionistas. Neste sentido, a ideia da governança corporativa ganhou

73 Cf. PINTO, Arthur R.; BRANSON, Douglas M. Understanding Corporate Law, p. 102.

74 Cf. PINTO, Arthur R.; BRANSON, Douglas M. Understanding Corporate Law, p. 103. 
destaque e relevância, sobretudo como uma forma de resposta a tais conflitos e minimização dos custos de monitoramento e de incentivos. Adriana Andrade e José Paschoal Rossetti, ao comentarem que as altíssimas remunerações dos CEOs norte-americanos no final dos anos 1990 representavam custos de agência muito elevados, explicam que uma das contrapartidas corretivas foi justamente a aprovação de planos de opção de compra ${ }^{75}$. Acrescentam, ainda, os referidos autores que esse tipo de mecanismo está se tornando uma das ferramentas das boas práticas de governança corporativa, de modo que nos Estados Unidos, por exemplo, em duas décadas o número de companhias que possuíam um plano de opção de ações aumentou em mais de $48 \%{ }^{76}$.

O que se espera nessa situação é que, mesmo com uma quantidade ínfima de ações, ao serem outorgados com opções de compra de ações, os beneficiários do plano passem a pensar conforme verdadeiros acionistas e agir de forma a buscar sempre o melhor desempenho para a companhia. Assim, ao alcançarem o sucesso institucional, também os participantes dos stock options plans seriam beneficiados com o crescimento da sociedade.

Ressalta-se, contudo, que a finalidade dos planos de opção de compra como forma de incentivo e alinhamento de condutas pode vir a ser manipulada, como no caso da Enron $^{77}$, no qual administradores se utilizaram desse benefício para fraudarem demonstrações contábeis e auferirem ganhos com a negociação de suas próprias ações ${ }^{78-79}$.

\footnotetext{
75 Segundo os referidos autores, "[a]inda que em sua maior parte esses valores sejam recompensados pelo desempenho operacional das corporações, eles têm sido julgados excessivos, conflitando com o interesse dos acionistas, no sentido de representarem custos de agência muito elevados. A contrapartida corretiva, que desde o final dos anos 80 , mas mais fortemente nos anos 90, vem sendo sugerida e crescentemente praticada é a ligação das remunerações anuais ao desempenho das ações das companhias. Desta forma, tem-se tornado comum a recompensa dos altos executivos com stock options - opções de compra das ações da companhia a preços predeterminados. Trata-se de incentivo para a sustentação do desempenho das empresas e de seus valores de mercado em altos níveis, afetando a riqueza tanto dos acionistas quanto da direção executiva e, assim, harmonizando os seus interesses”. ANDRADE, Adriana; ROSSETTI, José Paschoal. Governança Corporativa, p. 93.

76 "Até o início dos anos 80, as stock options representavam 2\% da remuneração dos CEOs das companhias norte-americanas. Esta proporção subiu para 26\% em 1994, superando 50\% no final dos anos 90”. ANDRADE, Adriana; ROSSETTI, José Paschoal. Governança Corporativa, p. 93.

77 Para detalhes sobre as causas e consequências dos problemas envolvendo a Enron, cf. COFFEE JUNIOR, John C. What caused Enron? A capsule social and economic history of the 1990's. Working Paper, n. 214, jan. 2003. Disponível em: <http://ssrn.com/abstract_id=373581>. Acesso em: 27 abr. 2011.

78 Nesse sentido, José Edwaldo Tavares Borba esclarece que "na prática, têm ocorrido até mesmo certos exageros. Algumas companhias têm outorgado a seus altos executivos, especialmente a diretores, opções em excesso, de tal forma que, apresentando essas sociedades uma grande valorização de suas ações, viabiliza-se para esses administradores a oportunidade de realizar, às vezes no curto período de um ano, ganhos de dezenas de milhões de dólares. (...) Todavia, e desde que os exageros sejam colocados à parte, a opção de compra de ações poderá representar um eficiente veículo de co-participação do trabalho (empregados e executivos) nos resultados da empresa”. BORBA, José Edwaldo Tavares. Direito Societário. 9. ed. Rio de Janeiro: Renovar, 2004.

79 Outras desvantagens também podem ser suscitadas pela aprovação de planos de opção de compra de ações. Carla Lobo Olim Marote, utilizando os ensinamentos de Luis Alcalá-Zamora y Castillo e Guillermo Cabanellas Torres, aponta, entre outras desvantagens, as seguintes: “(i) só é possível sua aplicação naquelas empresas que
} 
Cabe aqui, portanto, a análise dos padrões de conduta que devem ser observados pelos administradores. A seguir, serão analisados os deveres impostos pela legislação brasileira aplicável.

estão estruturadas por meio de ações e participações; (ii) acarreta no acesso do empregado à informação, à consulta e ao controle da contabilidade; (iii) dilui-se o segredo empresarial, ao ter o empregado conhecido da estratégia da produção; (iv) não existe um critério unanimemente aceito para adjudicar as ações aos empregados, recorrendo-se a uma repartição proporcional a seus salários, o que mantém as diferenças e injustiças sociais; e (v) é necessário para sua implantação que os estatutos da sociedade não impeçam a incorporação de novos sócios”. MAROTE, Carla Lobo Olim. Participação dos empregados no capital da empresa: opção de compra de ações. São Paulo, 2003. 137 f. Dissertação (Mestrado). Faculdade de Direito, Universidade de São Paulo. p. 36 e 37. 


\section{DEVERES E RESPONSABILIDADES DOS ADMINISTRADORES}

A Lei das Sociedades por Ações, nos artigos 153 a 158, estabelece os principais deveres dos administradores de companhias. A análise dos referidos artigos demonstra uma clara inspiração do legislador pátrio na disciplina jurídica norte-americana dos deveres dos administradores, regulando obrigações e responsabilidades comparáveis aos chamados fiduciary duties dos beneficiários da gestão no trust ${ }^{80}$. Essa analogia, contudo, é imperfeita estrutural e funcionalmente. Primeiramente em razão do fato de que os administradores não são titulares dos bens sociais, diferentemente, portanto, do que ocorre com os trustees em relação aos bens do trust. Em segundo lugar, pelo fato de que a função do administrador é fazer os bens da companhia gerarem riquezas, e não simplesmente conservá-los ${ }^{81}$.

A doutrina norte-americana costuma subdividir os chamados fiduciary duties em três: (i) o dever de diligência (duty of due care); (ii) o dever de atuação dentro do objeto social (to act intra vires); e (iii) o dever de lealdade (duty of loyalty). O legislador brasileiro, inspirado no norte-americano, incluiu tais deveres no ordenamento, incluindo também nos artigos 153 a 158 da Lei das Sociedades por Ações, por exemplo, regras quanto ao conflito de interesses e ao dever de informar ${ }^{82}$.

\footnotetext{
80 A analogia com o trust "foi desenvolvida pelos tribunais britânicos e norte-americanos. Essa analogia (...) deve-se, historicamente, ao fato de que, antes de 1844, a maioria das então chamadas joint stock companies era 'não-incorporada' (unincorporated), ou seja, não era dotada de personalidade jurídica, e, portanto, utilizava-se o trustee para deter a propriedade dos bens da companhia. Muitas vezes, os próprios administradores eram os trustees. Ao julgar os administradores responsáveis, não havia diferença relevante para os tribunais se os mesmos eram autênticos trustees, ou meros representantes de uma companhia dotada de personalidade jurídica. Em consequência, os deveres fiduciários do conselho de administração acabaram se tornando mais ou menos idênticos aos deveres dos trustees, e estes últimos deveres sempre foram os mais abrangentes, tanto com relação ao seu conteúdo, quanto com relação à sua efetivação judicial”. HOPT, Klaus J. Deveres legais e conduta ética de membros do conselho de administração e de profissionais. Trad. Erasmo Valladão A. e N. França e Mauro Moisés Kertzer. Revista de Direito Mercantil, Industrial, Econômico e Financeiro, São Paulo: Malheiros, n. 144, p. 107-119, out./dez. 2006. p. 108-109.

81 Cf. ADAMEK, Marcelo Vieira von. Responsabilidade civil dos administradores de S/A, p. 43.

82 A Exposição de Motivos da Lei das Sociedades por Ações assim justifica esta seção da lei: "Os artigos 154 a 161 definem, em enumeração minuciosa, e até pedagógica, os deveres e responsabilidades dos administradores. É Seção da maior importância no Projeto porque procura fixar os padrões de comportamento dos administradores, cuja observância constitui a verdadeira defesa da minoria e torna efetiva a imprescindível responsabilidade social do empresário. Não é mais possível que a parcela de poder, em alguns casos gigantesca, de que fruem as empresas - e, através delas, seus controladores e administradores - seja exercido em proveito apenas de sócios majoritários ou dirigentes, e não da companhia, que tem outros sócios, e em detrimento, ou sem levar em consideração, os interesses da comunidade. As normas desses artigos são, em sua maior parte, meros desdobramentos e exemplificações do padrão de comportamento dos administradores definido pela lei em vigor
} 
Sem a pretensão de esgotar o tema, serão analisadas sumariamente as principais características de tais deveres sob a perspectiva da relação entre administradores e acionistas, isto é, do comportamento esperado dos administradores em face da outorga de opções no âmbito de um plano de opções de compra de ações.

\subsection{DEVER DE DILIGÊNCIA}

Nos termos do artigo 153 da Lei das Sociedades por Ações, no exercício de suas funções, o administrador deve empregar o cuidado e diligência que todo homem ativo e probo costuma empregar na administração dos seus próprios negócios ${ }^{83}$. Como se pode observar do texto legal, claramente baseado no modelo norte-americano, trata-se de critérios (ou standards) amplos, os quais podem se ajustar a diferentes situações, conforme circunstâncias específicas de diversas sociedades, não implicando, portanto, comportamentos rígidos e predeterminados.

Nos Estados Unidos, nos termos do Model Business Corporation Act, o dever de diligência deve ser interpretado de forma que os administradores exerçam seus cargos com boa-fé e de uma maneira que eles acreditem estar, razoavelmente, agindo no melhor interesse da companhia. Devem, ainda, coletar as informações necessárias para respaldar a tomada de

\footnotetext{
- o do 'homem ativo e probo na administração dos seus próprios negócios' ( $\$ 7^{\circ}$ do art. 116 do Decreto-lei ${ }^{\circ}$ 2.627) e, em substância, são as que vigoram, há muito tempo, nas legislações de outros povos; formuladas, como se encontram, tendo presente a realidade nacional, deverão orientar os administradores honestos, sem entorpecêlos na ação, com excessos utópicos. Servirão, ainda, para caracterizar e coibir abusos”. Disponível em: <http://www.cvm.gov.br/port/atos/leis/6404_Exposicao.asp>. Acesso em: 30 jan. 2012.

83 O modelo adotado no Brasil, portanto, seguiu a essência do bônus pater famílias romano. Segundo Marcelo Vieira Von Adamek, esse padrão de comportamento tem sido diverso em outros ordenamentos. Explica o referido autor que "[n]a Itália, por exemplo, até a reforma societária de 2003, fazia-se referência à diligência própria de mandatário e, na atualidade, é feita alusão 'à diligência requerida pela natureza de sua função e de sua específica competência' (CC it., art. 2.392). Já na Alemanha, o legislador adota o critério da diligência de diretor de diretor de empresa consciencioso (AktG de 1965, §93), mais específico e consentâneo com a importância das grandes companhias na economia. Em Portugal, há menção à diligência 'de um gestor criterioso e ordenado' (CSC, art. 64'). Na Argentina, mencionam-se a lealdade e a diligência 'de um buen hombre de negocios' (LSC, art. 59). Na suíça, é feita alusão à necessidade de atuar 'com toda diligência' (mir aller Sorgfalt), sem referência expressa a padrão comparativo (OR, art. 717). Na Inglaterra, decidiu-se que um diretor deve exibir na execução de suas tarefas pelo menos o grau de diligência que pode ser esperado de uma pessoa com o seu conhecimento e experiência. E, nos Estados Unidos da América, entende-se que 'a regra mais justa e satisfatória é o grau de cuidado e diligência que um diretor ordinariamente prudente deveria razoavelmente exercer numa posição semelhante sob circunstâncias similares'”. ADAMEK, Marcelo Vieira von. Responsabilidade civil dos administradores de S/A/, p. 122 e 123.
} 
suas decisões e realizar suas funções com o cuidado que uma pessoa ordinariamente prudente em uma situação semelhante exerceria sob circunstâncias similares ${ }^{84}$. Elucida Haroldo Malheiros Duclerc Verçosa afirmando que ${ }^{85}$ :

Os dados da experiência demonstram que o homem, agindo egoisticamente, costuma cuidar bem dos seus próprios interesses, procurando exercer a sua defesa da melhor maneira possível. É com este mesmo ânimo que os administradores devem agir à frente de uma companhia, exercitando suas atribuições legais e estatutárias.

No contexto do dever de diligência, é também importante compreender o chamando business judgment rule. Com origem na jurisprudência norte-americana, tal regra estabelece que as decisões negociais de administradores tomadas no âmbito de suas atividades não devem ser avaliadas em juízo. Presume-se que os administradores agiram de forma honesta e suas decisões foram racionalmente tomadas com base em dados e informações confiáveis ${ }^{86}$. Alan R. Palmiter explica que o business judgment rule pode ser justificado sob diferentes perspectivas $^{87}$. Em primeiro lugar, justifica-se em razão do fato de ser economicamente interessante a tomada de decisões arriscadas. Para auferirem maiores resultados, os acionistas esperam (e incentivam) que os administradores tomem decisões até um determinado ponto arriscadas, para que no futuro a companhia possa obter maiores retornos financeiros. Obviamente, determinados cuidados são exigidos, como a coleta de informações durante o

${ }^{84}$ Nesse sentido, Alan R. Palmiter afirma que "[m]any state statutes codify the standards for directorial behavior. Typical is MBCA §8.30 (as revised in 1998). Under the section, each individual director must discharge his duties in 'good faith' and act 'in a manner he reasonably believes to be in the best interest of the corporation.' MBCA §8.30(a). Collectively, members of the board must become informed in performing their decision-making and oversight functions with 'the care that a person in like position would reasonably believe appropriate under similar circumstances.' MBCA §8.30(b) (replacing early, more stringent standard of 'ordinarily prudent person')". PALMITER, Alan R. Corporations: examples and explanations. $5^{\text {th }}$ ed. New York: Aspen Publishers, 2006. p. 201 e 202.

85 VERÇOSA, Haroldo Malheiros Duclerc. Curso de Direito Comercial. v. 3. ed. São Paulo: Malheiros, 2008.p. 464.

${ }^{86}$ "As explained by the courts, the business judgment rule is a rebuttable presumption that directors in performing their functions are honest and well-meaning, and that their decisions are informed and rationally undertaken. In short, the business judgment rule presumes directors do not breach their duty of care”. PALMITER, Alan R. Corporations, p. 203.

87 "The business judgment presumption has been justified on different grounds: Encourages risk-taking. Shareholders expect the board to take business risks - the adage 'nothing ventured, nothing gained' is at the core of why shareholders invest. Without the business judgment rule, directors might exercise moribund caution. See Gagliardi v. Trifoods Int'l Inc., 683 A.2d 1049 (Del. Ch. 1996) (explaining that shareholders can absorb risk by investing in many companies). Avoids judicial meddling. Judges are not business experts. Further, derivative suit plaintiffs (and their lawyers) have incentives that may be at odds with the interests of the corporation and the body of shareholders. Corporate statutes reflect this notion and uniformly specify that corporate management is entrusted to the board of directors. Encourages directors to serve. Business persons detest liability exposure. The business judgment rule encourages qualified persons to become directors and take business risks without fear of being judged in hindsight”. PALMITER, Alan R. Corporations, p. 204. Grifos no original. 
processo decisório $^{88}$. Em segundo lugar, o business judgment rule se justifica por afastar a interferência judicial nos negócios sociais. A proteção garantida por esse mecanismo evita a análise de mérito por juízes a respeito de decisões negociais tomadas por administradores, visto que os magistrados, em regra, não possuem formação específica que lhes permita tal julgamento. Uma decisão equivocada por juízes poderia ocasionar sérios problemas para as atividades de uma companhia.

Por fim, justifica-se o business judgment rule também pelo fato de incentivar os administradores a servir a companhia. O business judgment rule encoraja pessoas qualificadas a se tornarem administradoras e a assumirem riscos sem receio de, posteriormente, serem julgadas e eventualmente responsabilizadas por seus atos. Dessa forma, nota-se a preocupação dos tribunais norte-americanos com a conduta dos administradores no processo decisório, e não com o mérito em si de suas decisões. No Brasil, essa conduta também tem sido adotada pelos tribunais, os quais apenas julgam casos de atuação negligente, sem entrar no mérito das decisões negociais ${ }^{89-90}$.

Sobre o tema, conveniente citar o caso In re Walt Disney Company Derivative Litigation, 906 A. 2d 27 que é um marco quanto à aplicação do business judgment rule. No caso mencionado, a decisão da corte de Delaware é emblemática, pois alterou o sentido do que à época a priori se esperava em relação a questionamentos quanto à remuneração de administradores $^{91}$. Trata-se do questionamento acerca da contratação de novo diretor (Sr. Michael Ovitz) e do pagamento em sua saída da companhia, após apenas 14 meses e sem demonstrar desempenho satisfatório, principalmente por meio de opções de compra de ações,

\footnotetext{
88 Marcelo Vieira Von Adamek, por essa forma de análise, explica que, na prática, “os administradores não são responsabilizados por decisões gerenciais em si negligentes (negligente substantive decisions), mas somente por decisões irracionais (egregious decisions ou irrational decisions) ou tomadas sem a devida coleta de informações e conselhos durante o iter decisório. Sobressai, daí, o dever de o administrador procurar obter informações durante a tomada de decisões”. ADAMEK, Marcelo Vieira von. Responsabilidade civil dos administradores de S/A/, p. 130 e 131.

89 Cf. JOSUÁ, Adriana. Governança Corporativa e Teoria da Agência, p. 110.

90 Ainda em relação ao tema do dever de diligência, é conveniente ressaltar a relação da conduta dos administradores com as deliberações de outros órgãos da sociedade. Age diligentemente não aquele administrador que simplesmente cumpre qualquer deliberação tomada em assembleia geral, mas sim aquele que cumpre as deliberações válidas. Sobre o tema, cf. FRANÇA, Erasmo Valladão Azevedo e Novaes. Invalidade das deliberações de assembleia das S.A. São Paulo: Malheiros, 1999. p. 61 e ss. Ainda sobre a obrigatoriedade de os administradores cumprirem todas as deliberações da assembleia geral, conclui Marcelo Vieira Von Adamek que "[a] bem da verdade, o administrador que, de forma cega e submissa, limitar-se a dar cumprimento a toda e qualquer deliberação de outro órgão jamais estará dando regular cumprimento ao dever de diligência; ao contrário, estará positivamente violando-o (por ser passivo, e não ativo) e, com isso, expondo-se à responsabilidade civil, sem que possa invocar a falta alheia como causa excludente de sua própria responsabilidade”. ADAMEK, Marcelo Vieira von. Responsabilidade civil dos administradores de S/A/, p. 142.

91 Cf. COX, James D.; TALLEY, Eric. Hope and Despair in the Magic Kingdom: In Re Walt Disney Company Derivative Litigation. In: MACEY, Jon. (Ed.). Iconic Cases in Corporate Law, maio 2008. p. 13.
} 
de aproximadamente US\$ 140 milhões. Em suma, dentre outros argumentos, os autores da ação alegaram que o diretor contratado era amigo pessoal do diretor presidente, que o mesmo não tinha experiência no ramo e que documentos internos da própria companhia alertavam que o diretor contratado não tinha as qualificações exigidas para o cargo. A corte, no entanto, decidiu que a contratação do diretor em questão foi feita com boa-fé, baseada em informações confiáveis e no melhor interesse da companhia, ou seja, com base no business judgment rule, a decisão de contratar o Sr. Michael Ovitz não poderia ser contestada ${ }^{92}$.

\section{2. $\quad$ Finalidade das Atribuições e Desvio de Poder}

A Lei das Sociedades por Ações trata, em seu artigo 153, conforme acima analisado, da diligência e do cuidado que o administrador deve empregar no exercício de suas atividades. Aborda, assim, aspectos subjetivos do comportamento do administrador. Em seu artigo 154, por sua vez, dispõe sobre os elementos objetivos que devem orientar a conduta do administrador nas suas atividades ${ }^{93}$ : “O administrador deve exercer as atribuições que a lei e o estatuto lhe conferem para lograr os fins e no interesse da companhia, satisfeitas as exigências do bem público e da função social da empresa”.

Assim, estabelece o artigo 154 da Lei das Sociedades por Ações que os administradores devem exercer as atribuições a eles impostas pela lei e pelo estatuto a fim de atingir o fim social da sociedade. Ressalta-se que a interpretação da expressão "fim social” não deve limitá-la ao objeto social ${ }^{94}$ da companhia, conforme descrito minuciosamente no estatuto social (artigo $2^{\circ}, \S 2^{\circ}$, da Lei das Sociedades por Ações); o fim social deve também compreender o objetivo fim de toda sociedade, que é a obtenção de lucros ${ }^{95}$. Dessa forma,

\footnotetext{
92 Para análise do caso, cf. COX, James D.; TALLEY, Eric. Hope and Despair in the Magic Kingdom.

93 Cf. CARVAlhOSA, Modesto. Comentários à Lei de Sociedades Anônimas. v. 3. São Paulo: Saraiva, 2009. p. 278.

94 Pela expressão "lograr os fins” da companhia, Fran Martins explica, “em palavras mais compreensíveis”, que os administradores devem agir com o intuito de atingir o objeto social da companhia. MARTINS, Fran. Comentários à lei das sociedades anônimas. 4. ed., rev. e atual. por Roberto Papini. Rio de Janeiro: Forense, 2010. p. 574.

95 Modesto Carvalhosa explica que "[a]ssim, o administrador tem compromisso legal apenas de envidar todos os esforços visando ao cumprimento do fim social. Aqui a expressão 'fim social' tem duplo significado. $\mathrm{O}$ primeiro refere-se à lucratividade, que é o objeto da companhia (Art. $2^{\circ}$ ). Deve o administrador diligenciar para que seja alcançada a maximização dos lucros. O outro sentido da expressão legal é de objeto social. Deve o
} 
agirá conforme o fim social o administrador que atuar em prol desses objetivos e em atenção às “exigências do bem público e da função social da empresa"96.

O parágrafo primeiro do artigo 154 estabelece que os deveres que o administrador têm perante a companhia são os mesmos para todos os administradores, independentemente de quem o tenha elegido. Mesmo que as suas decisões venham a contrariar as vontades dos acionistas que o elegeram, o administrador deve sempre agir em prol dos interesses da companhia. Não obstante, é esperado que o administrador eleito por um determinado acionista ou grupo de acionistas, preferencialmente procurará atender as vontades de tal acionista ou grupo de acionistas. Contudo, sempre que tais interesses forem contraditórios aos da companhia, o administrador deverá priorizar estes últimos, visto que tem obrigações frente à companhia, e não se confunde, portanto, com um representante dos interesses de referido acionista ou grupo de acionistas.

O artigo 154 da Lei das Sociedades por Ações estabelece, ainda, um rol de atos que são vedados aos administradores: (i) praticar ato de liberdade à custa da companhia; (ii) sem prévia autorização da assembleia geral ou do conselho de administração, tomar por empréstimo recursos ou bens da companhia, ou usar, em proveito próprio, de sociedade em que tenha interesse, ou de terceiros, os seus bens, serviços ou crédito; e (iii) receber de terceiros, sem autorização estatutária ou da assembleia geral, qualquer modalidade de vantagem pessoal, direta ou indireta, em razão do exercício de seu cargo.

A primeira vedação refere-se aos atos de diminuição do patrimônio social, sem o respectivo benefício ou vantagem econômica ${ }^{97}$. Os administradores devem sempre buscar o crescimento do patrimônio social, com vistas à consecução dos objetivos da sociedade e da obtenção de lucros. Podem, inclusive, com a expressa autorização do conselho de administração ou da diretoria, praticar atos gratuitos ${ }^{98}$ razoáveis em benefício dos empregados

administrador observar estritamente o objeto social, abstendo-se de desconsiderá-lo no exercício de suas atividades”. CARVALHOSA, Modesto. Comentários à Lei de Sociedades Anônimas, v. 3, p. 279.

96 Para os fins do presente trabalho, tendo em vista a limitação do tema deste estudo, dá-se ênfase à atuação do administrador no âmbito das atribuições a eles atribuídas pela lei e pelo estatuto.

97 Cf. VALVERDE, Trajano de Miranda. Sociedades por ações. v. 2. Rio de Janeiro: Forense, 1941. p. 39.

98 Sobre atos gratuitos que, aparentemente, não geram quaisquer ônus para a companhia, Marcelo Vieira Von Adamek adverte que "certos atos são gratuitos na sua aparência, mas não na sua essência, ou porque têm caráter remuneratório, ou por estarem inseridos no contexto maior de uma atividade empresarial. A prática de ato gratuito não se pode dizer, sempre, incompatível com a atividade empresarial, precisamente porque ato e atividade são realidades distintas. Por isso, a gratuidade de um ato específico, desde que relacionado ao exercício de atividade empresarial (esta sim de caráter econômico, voltada à criação de riquezas e movida pelo intento lucrativo, sempre pressuposto no exercício da empresa), não incide no citado veto legal”. ADAMEK, Marcelo Vieira von. Responsabilidade civil dos administradores de S/A/, p. 150 e 151. 
ou da comunidade de que participe a sociedade, considerando suas responsabilidades sociais (conforme artigo 154, § $4^{\circ}$, da Lei das Sociedades por Ações).

A segunda vedação proíbe o administrador de, sem a prévia autorização da assembleia geral ou do conselho de administração, (i) tomar por empréstimo recursos ou bens da companhia ou (ii) usar, em proveito próprio, de sociedade em que tenha interesse, ou de terceiros, os seus bens, serviços ou crédito. Em relação à primeira parte, destaca-se que não só a celebração de um contrato de mútuo, como também a de um contrato de locação ou de comodato deve ser previamente autorizada, sendo que se o mútuo for concedido a taxas inferiores àquelas usualmente praticadas no mercado ou o bem for locado por aluguel abaixo do valor que seria praticado com terceiros, um ato de liberalidade estaria configurado ${ }^{99}$. A parte final do dispositivo veda que o administrador use, ou permita que terceiros usem, os bens ou os serviços da companhia para proveito próprio, visto que os bens sociais devem ser utilizados no interesse da companhia.

Por fim, a última vedação proíbe que os administradores recebam de terceiros, sem autorização da assembleia ou do estatuto social, qualquer modalidade de vantagem pessoal em razão do exercício de seu cargo. Assim, tal vedação procura inibir que a possibilidade de receber ou a efetiva oferta, por parte de terceiros, de alguma espécie de benefício possa vir a influenciar a tomada de decisões dos administradores.

\section{3.}

\section{DEVER DE LEALDADE}

Nos termos do artigo 155 da Lei das Sociedades por Ações, o "administrador deve servir com lealdade à companhia e manter reserva sobre os seus negócios (...)”. Assim, a lei societária, em primeiro lugar, estabelece um padrão amplo de comportamento para, em seguida, dispor um rol exemplificativo de condutas e comportamentos desleais.

A primeira vedação expressa da lei refere-se às oportunidades empresariais de que o administrador tenha tido conhecimento em razão do exercício de seu cargo. Não pode o administrador se valer de tal conhecimento para, em benefício próprio ou de terceiro, auferir

99 Cf. LUCENA, José Waldecy. Das sociedades anônimas - comentários à lei (arts. 121 a 188). v. 2. Rio de Janeiro: Renovar, 2009. p. 473. 
vantagens, mesmo que não cause prejuízos à companhia. Trata-se de uma vedação em caráter absoluto.

Em seguida, a lei proíbe ao administrador omitir-se no "exercício ou proteção de direitos da companhia ou, visando à obtenção de vantagens, para si ou para outrem, deixar de aproveitar oportunidades de negócio de interesse da companhia”. Ressalta-se que a lei não buscou penalizar toda e qualquer omissão, mas unicamente aquelas oportunidades inequívocas de negócio; ou seja, não pode o administrador ser responsabilizado por eventuais abstenções frente a possibilidades de negócios que sejam discutíveis ou que representem riscos ou resultados incertos para a companhia. O dever de lealdade, portanto, deve ser sempre ponderado juntamente com o dever de diligência acima analisado. É de interesse da companhia que o administrador assuma determinados riscos a fim de auferir maiores ganhos, porém, nem sempre o negócio deve ser realizado e nem sempre deve o administrador absterse de realizar o negócio.

Já o inciso III do artigo 155 da Lei das Sociedades por Ações proíbe o administrador de adquirir, para revender com lucro, bem ou direito que sabe necessário à companhia, ou que esta tencione adquirir.

Nos Estados Unidos, o dever de lealdade (duty of loyalty) é utilizado para endereçar os conflitos de interesses dos fiduciários e prima pelos interesses da companhia ${ }^{100}$. Referido dever proíbe que os administradores obtenham vantagens por meio de negócios fraudulentos ou injustos e é capaz de abranger situações não previstas expressamente por se tratar de um dever genérico. Alan R. Palmiter cita alguns exemplos de situações em que pode ocorrer a quebra do dever de lealdade, entre as quais estão: negociação em benefício próprio, remuneração de executivos e negociação com informações privilegiadas ${ }^{101}$.

\footnotetext{
100 “The duty of loyalty addresses fiduciaries' conflicts of interest and requires fiduciaries to put corporation's interests ahead of their own - that is, fiduciaries cannot serve two masters. Corporate fiduciaries breach their duty of loyalty when they divert corporate assets, opportunities, or .information for personal gain”. PALMITER, Alan R. Corporations, p. 192.

101 "Flagrant Diversion. Diversion can be as simple, and as reprehensible, as a corporate official stealing tangible corporate assets. (...). Self-Dealing. Diversion can be masked in a self-dealing transaction. (...). Executive Compensation. When a director or officer sells his executive services to the corporation, diversion can occur if the executive's compensation exceeds the fair value of his services. (...). Usurping Corporate Opportunity. When a corporate fiduciary seizes for herself a desirable business opportunity that the Corporation likely would have taken and profited from, diversion occurs if the fiduciary denies the Corporation the opportunity to expand profitably. (...). Disclosure to Shareholders. Corporate officials who provide shareholders false or deceptive information, on which the shareholders rely to their detriment, not only undermine corporate credibility and transparency, but frustrate shareholders' expectations of fiduciary honesty and accountability. (...). Trading on Inside Information. When a fiduciary knows of confidential corporate information - such as the impending acquisition of another company - and he buys the target's stock, diversion can occur if the acquisition price to the Corporation rises because of these purchases. (...). Selling Out. A corporate official who accepts a
} 
É conveniente ressaltar ainda que nos Estados Unidos o tema dos stock option plans é comumente tratado no âmbito do dever de lealdade. Ao analisar esse dever, a doutrina norteamericana, conforme acima mencionado, costuma destacar dentre as hipóteses de violação do dever de lealdade as situações referentes à remuneração de executivos. Dentre as modalidades de remuneração, os autores norte-americanos destacam os planos de opção tendo em vista suas particularidades, as quais serão tratadas a seguir.

Por fim, o artigo 155 da Lei das Sociedades por Ações apresenta disposições sobre a vedação à utilização de informações relevantes para a obtenção, para si ou para outrem, de vantagens no mercado de valores mobiliários. A seguir, serão apresentadas sumariamente suas principais características.

Os parágrafos $1^{\circ}$ a $4^{\circ}$ do artigo 155 da Lei das Sociedades por Ações trazem as regras referentes à repressão do chamado insider trading ${ }^{102}$, relacionado com a questão da assimetria de informações ${ }^{103}$. Assim, o administrador de companhia aberta deve guardar sigilo sobre qualquer informação - obtida em razão do seu cargo - (i) que ainda não tenha sido divulgada para conhecimento do mercado e (ii) que seja capaz de influenciar de modo considerável a cotação de valores mobiliários, sendo que lhe é vedado, ainda, utilizar tal informação para obter, para si ou para outrem, vantagem mediante compra ou venda de valores mobiliários.

Em relação à informação obtida pelo administrador “em razão de seu cargo”, Luiz Antônio de Sampaio Campos defende que mesmo aquelas informações obtidas por razões

bribe to sell her corporate office breaches a fiduciary duty of loyalty. (...). Entrenchment. A manager who uses the corporate governance machinery to protect his incumbency effectively diverts control from the shareholders to himself (...)”. PALMITER, Alan R. Corporations, p. 192-194. Grifos no original.

102 É vasta a bibliografia sobre o tema do insider trading, o qual, por razão de limitação do escopo, não será aprofundado no presente trabalho. Sobre o tema, cf.: LEÃES, Luiz Gastão Paes de Barros. Mercado de capitais e insider trading. São Paulo: Revista dos Tribunais, 1982; PROENÇA, José Marcelo Martins. “Insider trading”: regime jurídico do uso de informações privilegiadas no mercado de capitais. São Paulo: Quartier Latin, 2005.

103 Sobre o tema da assimetria de informações, cf. AKERLOF, George A. The Market for "Lemons": quality uncertainty and the Market Mechanism. The Quarterly Journal of Economics, v. 84, n. 3, ago. 1970, p. 488-500. Referido autor utiliza o mercado de carros usados nos Estados Unidos para explicar como a assimetria de informações pode influenciar negativamente o mercado. Em suma, com base na chamada "seleção adversa" (adverse selection), Akerlof explica que o valor mais baixo de um determinado bem se dá em razão das incertezas geradas a partir da assimetria de informações entre vendedores e compradores. 
outras que não o exercício do cargo e que digam respeito à companhia devem estar sujeitas ao dever de sigilo. Sustenta referido autor que o dever de lealdade é integral e indiviso, razão pela qual seria incompatível com os deveres dos administradores a divulgação de tal informação ${ }^{104}$.

É possível ainda afirmar que o dever de sigilo e o combate ao insider trading têm respaldo na Constituição Federal, com base na ordem econômica e em alguns de seus princípios, como o da isonomia e o da valorização do trabalho humano e da livre iniciativa. Quanto à repressão aos insiders, suas ações podem ser punidas com base em sanções civis de reparação de prejuízos (fundamentadas na responsabilidade civil pela prática de atos ilícitos), bem como em penalidades administrativas e criminais.

A questão do sigilo e a repressão ao insider trading é fundamental para o devido funcionamento do mercado de capitais. A igualdade de oportunidade e informação é pressuposto para o regular funcionamento do mercado, o que mitiga o risco de negócios “assimétricos” em razão de informações disponíveis para apenas uma das partes do negócio ${ }^{105}$, atraindo investidores e repelindo a atuação de simples especuladores ${ }^{106}$.

Tema de extrema relevância para o direito societário, o conflito de interesses está disciplinado no artigo 156 da Lei das Sociedades por Ações nos seguintes termos ${ }^{107}$ :

\footnotetext{
${ }^{104}$ Conclui, ainda, referido autor que o "administrador deve, então, guardar reserva sobre toda e qualquer informação não pública de que tenha tido conhecimento contemporaneamente ao exercício do cargo de administrador, não importando que esta tenha sido obtida em razão de relação social, familiar ou mesmo inadvertidamente ou por descuido de terceiros que desconheciam a presença do administrador do local ou a ocupação do cargo". LAMY FILHO, Alfredo; BULHÕES PEDREIRA, José Luiz. Direito das companhias. Rio de Janeiro: Forense, 2009. p. 1143 e 1144.

${ }^{105}$ Ressalta-se que não apenas o administrador está vinculado ao dever de sigilo. O administrador pode ser indiretamente responsabilizado em razão da violação do dever de sigilo por subordinados ou terceiros de confiança (artigo 155, § 2 , da Lei das Sociedades por Ações), o que a doutrina norte-americana costuma chamar de insiders secundários ou tippees.

${ }^{106}$ Marcelo Vieira Von Adamek explica que a "atuação no mercado de agentes com informações privilegiadas rompe o indispensável equilíbrio e gera, de um lado, prejuízos àqueles que não tiveram acesso aos dados passíveis de influir na cotação dos valores mobiliários e, por consequência, na sua decisão pessoal de investir e, de outro lado, ocasiona ganhos indébitos àqueles que se aproveitaram ilicitamente de sua posição junto à companhia emissora dos valores mobiliários”. ADAMEK, Marcelo Vieira von. Responsabilidade civil dos administradores de S/A/, p. 169.

${ }^{107} \mathrm{O}$ tema do conflito de interesses também é abordado na Lei das Sociedades por Ações quando esta trata do direito de voto dos acionistas (artigo 115). Para análise detalhada sobre o tema, cf. FRANÇA, Erasmo Valladão
} 
É vedado ao administrador intervir em qualquer operação social em que tiver interesse conflitante com o da companhia, bem como na deliberação que a respeito tomarem os demais administradores, cumprindo-lhe cientificá-los do seu impedimento e fazer consignar, em ata de reunião do conselho de administração ou da diretoria, a natureza e extensão do seu interesse.

Nota-se, portanto, que o legislador brasileiro optou por não definir o que seria o conflito de interesses, mas sim por caracterizá-lo de forma negativa.

Assim, compreende as hipóteses em que os interesses do administrador conflitam com os da companhia, como quando o administrador é contraparte em negócio com a companhia ou quando possa vir a ser beneficiado, direta ou indiretamente, em razão de negócio a ser realizado pela companhia ${ }^{108}$. Ressalta-se, contudo, que não fica o administrador proibido de contratar com a companhia. Não deve o administrador, apenas, intervir no negócio, seja opinando na sua realização, seja apresentando sugestões/críticas que viabilizem a operação. Ademais, a lei estabelece que o administrador somente pode contratar com a companhia em condições razoáveis e equitativas (artigo 156, § $1^{\circ}$, da Lei das Sociedades por Ações), conforme aquelas que prevalecem no mercado ou nas quais a companhia contrataria com terceiros $^{109}$.

Para os fins da presente dissertação, destaca-se que nos Estados Unidos a remuneração dos administradores (executive compensation) é comumente analisada sob o enfoque do conflito de interesses, uma vez que em muitos casos é o próprio conselho (board) que aprova a remuneração dos administradores (conselheiros e/ou diretores) ${ }^{110}$. Nesse sentido, a utilização indevida dos planos de opção de compra de ações, estudados no âmbito da executive compensation nos Estados Unidos, é entendida como um problema de agência, tendo em vista que o administrador tem interesse conflitante com o da companhia ao estabelecer sua própria remuneração. Os planos de opção, contudo, serão analisados mais profundamente adiante na presente dissertação.

\footnotetext{
Azevedo e Novaes. Conflitos de Interesses nas Assembléias de S.A. São Paulo: Malheiros, 1993. A importância do tema pode também ser observada na exposição de motivos da lei: "O artigo 115 cuida dos problemas do abuso do direito de voto e do conflito de interesses entre o acionista e a companhia. Trata-se de matéria delicada em que a lei deverá deter-se em alguns padrões necessariamente genéricos, deixando à prática e à jurisprudência margem para a defesa do minoritário sem inibir o legítimo exercício do poder de maioria, no interesse da companhia e da empresa".

${ }^{108}$ Cf. JOSUÁ, Adriana. Governança Corporativa e Teoria da Agência, p. 117.

${ }^{109}$ Fran Martins explica que a lei busca evitar que haja prejuízos para a sociedade em razão da participação de um administrador no negócio por aquela praticado, o que constituiria regalia para o administrador e, consequentemente, dano pra a sociedade, seus acionistas e até mesmo terceiros. Cf. MARTINS, Fran. Comentários à lei das sociedades anônimas, p. 586.

${ }^{110}$ Sobre o tema, cf. BEBCHUK, Lucian Arye; FRIED, Jesse M. Executive compensation as an agency problem. Journal of Economics Perspectives, n. 17, p. 71-92, 2003. Disponível em: <http://www.law.harvard.edu/programs/olin_center/>. Acesso em: 07 fev. 2012.
} 
O dever de informar, ou a obrigação de disclosure, como é comumente chamando, obriga os administradores a fornecerem aos acionistas, e, conforme o caso, ao mercado, todas as informações relativas aos negócios da sociedade, mantendo-os devidamente informados sobre deliberações e fatos que possam interferir na decisão do acionista/investidor em comprar, vender ou, de qualquer outra forma, negociar valores mobiliários. Trata-se de um dever que o administrador assume ao aceitar a sua eleição, e cujo não cumprimento implica a responsabilização do administrador - e não da companhia -, sendo cabível, inclusive, ação desta contra aquele.

Assim, a lei estabelece que o administrador de companhia aberta deve divulgar uma série de informações, tais como "declarar, ao firmar o termo de posse, o número de ações, bônus de subscrição, opções de compra de ações e debêntures conversíveis em ações, de emissão da companhia e de sociedades controladas ou do mesmo grupo, de que seja titular” (artigo 157 da Lei das Sociedades por Ações). Adicionalmente, a lei também determina que, a pedido de acionistas que representem $5 \%$ ou mais do capital social ${ }^{111}$, o administrador da companhia aberta é obrigado a revelar para a assembleia geral ordinária ${ }^{112-113}$ : (i) o número dos valores mobiliários de emissão da companhia ou de sociedades controladas, ou do mesmo grupo, que tiver adquirido ou alienado, diretamente ou através de outras pessoas, no exercício anterior; (ii) as opções de compra de ações que tiver contratado ou exercido no exercício anterior; (iii) os benefícios ou vantagens, indiretas ou complementares, que tenha recebido ou esteja recebendo da companhia e de sociedades coligadas, controladas ou do mesmo grupo; (iv) as condições dos contratos de trabalho que tenham sido firmados pela companhia com os

\footnotetext{
${ }^{111}$ Destaca-se que a CVM pode reduzir referido percentual, conforme escala fixada em função do capital social (artigo 291 da Lei das Sociedades por Ações).

112 A informação é prestada à assembleia geral, isto é, a todos os presentes na reunião. Nesse sentido, caso seja feito uso inadequado da informação divulgada, será responsável o acionista que fizer uso indevido da mesma, e não o acionista que a solicitou. Cf. LAMY FILHO, Alfredo; BULHÕES PEDREIRA, José Luiz. Direito das companhias, p. 1178.

113 O intuito da norma é dar ampla divulgação aos acionistas sobre a situação, presente e passada, dos administradores, evitando, assim, que sejam praticados atos prejudiciais à companhia e aos acionistas. É claro que seria inconveniente que em todas as assembleias gerais os administrador tivessem que interromper suas atividades (e a própria assembleia) para prestar informações. Contudo, a limitação imposta pelo legislador de somente permitir que os acionistas (com mais de $5 \%$ do capital social) solicitem informações aos administradores uma vez ao ano (no âmbito da assembleia geral ordinária), parece equivocada, uma vez que o pedido deveria ser também autorizado em assembleias extraordinárias.
} 
diretores e empregados de alto nível; e (v) quaisquer atos ou fatos relevantes nas atividades da companhia.

Exige a lei ainda que sejam tornadas públicas informações referentes à vida da sociedade. Por meio de comunicados à bolsa de valores e de divulgação via imprensa, os administradores de companhias abertas são obrigados a comunicar qualquer deliberação da assembleia geral ou dos órgãos de administração da companhia ou fato relevante ocorrido nos seus negócios que possam influir consideravelmente na decisão dos investidores do mercado sobre vender ou comprar valores mobiliários emitidos pela companhia (artigo 157, § $4^{\circ}$, da Lei das Sociedades por Ações) ${ }^{114}$.

Assim, à primeira vista, o dever de informar e o dever de sigilo acima comentado podem parecer contraditórios. Tal contradição, no entanto, carece de fundamentação. Deve o administrador ponderar em que momento deve fazer a divulgação de determinada informação, para não prejudicar a própria companhia ${ }^{115}$. Enquanto o dever de sigilo impõe ao administrador a obrigação de não deixar que ocorram vazamentos de informações sigilosas e reservadas da companhia a pessoas que delas possam fazer uso e, com isso, fraudar os interesses dos acionistas e investidores ${ }^{116}$, o dever de informar prevê que toda e qualquer informação relevante (“que possa influir, de modo ponderável, na decisão dos investidores do mercado de vender ou comprar valores mobiliários emitidos pela companhia”) relacionada aos negócios da companhia deve ser prontamente divulgada. Dessa forma, os administradores poderão recusar-se a prestar a informação ou deixar de divulgá-la se entenderem que sua revelação porá em risco interesse legítimo da companhia. Cabe à CVM, a pedido dos administradores ou de qualquer acionista, ou ainda por iniciativa própria, decidir sobre a prestação de informação e responsabilizar os administradores, se for o caso (artigo 157, § $5^{\circ}$, da Lei das Sociedades por Ações) ${ }^{117}$.

\footnotetext{
${ }^{114}$ A CVM regulou a matéria por meio da Instrução $\mathrm{n}^{\circ}$ 358, de 3 de janeiro de 2002, que dispõe sobre a "divulgação e uso de informações sobre ato ou fato relevante relativo às companhias abertas, disciplina a divulgação de informações na negociação de valores mobiliários e na aquisição de lote significativo de ações de emissão de companhia aberta, estabelece vedações e condições para a negociação de ações de companhia aberta na pendência de fato relevante não divulgado ao mercado, (...) e dá outras providências”.

${ }_{115}$ Modesto Carvalhosa explica que o "dever de guardar sigilo está dialeticamente relacionado com a obrigação de revelar ao público a informação relevante, no exato momento em que sua divulgação não mais afete os interesses da companhia”. CARVALHOSA, Modesto. Comentários à Lei de Sociedades Anônimas, v. 3, p. 313.

116 Cf. CARVALHOSA, Modesto. Comentários à Lei de Sociedades Anônimas, v. 3, p. 302.

${ }^{117}$ Em síntese, Marcelo Vieira Von Adamek afirma que "[o] que não pode o administrador é utilizar-se da informação sigilosa em benefício próprio ou de terceiro: deve ou divulgar amplamente o fato relevante (se disso não puder resultar prejuízo a legítimo interesse da companhia) ou se abster de utilizá-lo em proveito próprio (disclose or refrain from trading)". ADAMEK, Marcelo Vieira von. Responsabilidade civil dos administradores de S/A/, p. 178.
} 
O que deve ficar claro em relação ao dever de informar frente ao dever de sigilo é que não obrigatoriamente o investidor tem que obter bons resultados. O investidor fará um negócio com base em seu julgamento e livre-arbítrio, decidindo até que ponto está disposto a aceitar os riscos relacionados ao negócio. Diante de maus retornos aos investimentos, não pode o investidor culpar a companhia ou seus administradores, caso estes tenham prestado as informações necessárias para o negócio em questão.

Por fim, a lei acionária prevê que os administradores de companhia aberta devem informar, imediatamente, à CVM e às bolsas de valores ou entidades de mercado de balcão organizado nas quais os valores mobiliários de emissão da companhia estejam admitidos à negociação, as modificações em suas posições acionárias na companhia (artigo 157, § 6º da Lei das Sociedades por Ações). Assim, a norma pretende manter sempre atualizadas as posições acionárias declaradas quando da assinatura do termo de posse do administrador. Destaca-se que a Lei $n^{\circ} 10.303$, de 31 de outubro de 2001, que acrescentou o $\S 6^{\circ}$ ao artigo 157 da Lei das Sociedades por Ações, não previu as modificações nos demais valores mobiliários previstos no caput do artigo 157 (referindo-se, apenas, a "posições acionárias na companhia”), bem como não abrangeu as posições em "sociedades controladas ou do mesmo grupo” de que o administrador seja titular. Para José Waldecy Lucena, uma interpretação literal do referido $\S 6^{\circ}$ levaria a um enorme enfraquecimento da norma no combate ao insider trading, motivo pelo qual deveria haver uma harmonização entre caput e $\S 6^{\circ}$ do artigo 157 da Lei das Sociedades por Ações ${ }^{118}$.

Feitas essas considerações, e diante do fato de que o artigo $168, \S 3^{\circ}$, da Lei das Sociedades por Ações está inserido no Capítulo XIV, sobre a modificação do capital social, também devem ser analisados os planos de opção de compra sob a ótica do capital social, em especial a do capital autorizado.

${ }^{118}$ Cf. LUCENA, José Waldecy. Das sociedades anônimas, v. 2, p. 546. 
Dispõe o artigo 168, $\S 3^{\circ}$, da Lei das Sociedades por Ações que “o estatuto pode prever que a companhia, dentro do limite de capital autorizado, e de acordo com plano aprovado pela assembleia geral, outorgue opção de compra de ações a seus administradores ou empregados, ou a pessoas naturais que prestem serviços à companhia ou a sociedade sob seu controle”, independentemente de reforma estatutária. Para os fins deste capítulo, será abordado apenas o capital autorizado, que é de fundamental relevância para a compreensão dos planos de opção de compra no Brasil e de suas principais características, a respeito das quais se discorrerá adiante.

4.1.

\section{CARACTERÍSTICAS FUNDAMENTAIS}

O capital social costuma ser caracterizado como a principal garantia dos credores da sociedade $^{119}$. É formado por meio de contribuições dos acionistas, as quais, por sua vez, servem à sociedade para a exploração de seu objeto social. Compõe o patrimônio da companhia, não se confundindo com o mesmo ${ }^{120}$. Em determinados casos, no entanto, os acionistas podem antever e antecipadamente concordar com futuras contribuições à sociedade. Assim, o capital autorizado, conforme prescrito no artigo 168 da Lei das Sociedades por Ações, é aquele montante de capital que pode ser aumentado sem a necessidade de alteração imediata do estatuto social da companhia visto já ter sido previamente autorizado no mesmo $^{121}$.

\footnotetext{
${ }^{119}$ Sobre o tema, cf. LORIA, Eli. Estrutura e função do capital social na companhia aberta. São Paulo, 2009. 132 f. Dissertação (Mestrado). Faculdade de Direito, Universidade de São Paulo.

${ }^{120}$ Cf. TEIXEIRA, Egberto Lacerda; GUERREIRO, José Alexandre Tavares. Das sociedades anônimas no direito brasileiro, v. 1, p. 139.

${ }^{121}$ Para Rubens Requião, a grande vantagem desse sistema de formação de capital social "é permitir que a sociedade obtenha autofinanciamento de seu capital de giro, de conformidade com suas necessidades financeiras, com a venda de suas ações, sem maiores obstáculos. Ou no caso de aumento de capital pela conversão de
} 
A autorização prévia do aumento do capital social permite maior eficiência da companhia. Uma vez autorizado, os administradores não precisam observar as formalidades legais de convocação e instalação de assembleias para deliberações acerca do aumento de capital, tornando todo o processo de capitalização da companhia mais célere ${ }^{122}$.

Para que essa flexibilidade na alteração do capital social seja permitida, contudo, o estatuto deve especificar, nos termos do artigo 168, § $1^{\circ}$, da Lei das Sociedades por Ações: (i) o limite de aumento, em valor do capital ou em número de ações, e as espécies e classes das ações que poderão ser emitidas; (ii) o órgão competente para deliberar sobre as emissões, que poderá ser a assembleia geral ou o conselho de administração; (iii) as condições a que estiverem sujeitas as emissões; e (iv) os casos ou as condições em que os acionistas terão direito de preferência para subscrição ou os casos de inexistência desse direito (nos termos do artigo 172 da Lei das Sociedades por Ações).

4.2.

\section{EMISSÃo DE AÇõES NOS LIMITES DA AUTORIZAÇÃo}

Conforme mencionado, uma vez que a assembleia geral ou o conselho de administração tenham sido autorizados a aumentar o capital social dentro de um determinado limite, a emissão de ações, se assim aprovada, deve necessariamente se dar em conformidade com o previsto no estatuto social. Seja um determinado montante de ações, seja uma cifra específica, a emissão de ações deve se submeter aos limites impostos pelo estatuto. O estatuto deve estabelecer, ainda, as espécies e classes de ações a serem emitidas. Com relação a esse ponto específico, a legislação brasileira difere de outras, como a italiana e a espanhola, visto que estas admitem somente a emissão de ações ordinárias ${ }^{123}$.

debêntures em ações ou em outras hipóteses, como de bônus de subscrição, etc. A qualquer momento pode-se emitir e colocar novas ações, sem quaisquer das enfadonhas e onerosas formalidades ocorrentes no caso de capital fixo”. REQUIÃO, Rubens. Curso de direito comercial. v. 2. 23. ed. São Paulo: Saraiva, 2003. p. 64.

${ }^{122}$ No mesmo sentido, Modesto Carvalhosa ensina que "o fundamento para a adoção do regime de capital autorizado é o da agilização da companhia, mediante a dispensa de formalidades que entravam a obtenção mais rápida de novos capitais, o que não é possível no regime de capital fixo, o qual demanda a deliberação para aprovação e homologação do aumento pela assembleia geral”. CARVALHOSA, Modesto. Comentários à Lei de Sociedades Anônimas, v. 3, p. 509.

123 "O fundamento dessa restrição é a manutenção do status quo dos acionistas, dentro do princípio de que a emissão de ações preferenciais é da competência exclusiva da assembleia geral”. CARVALHOSA, Modesto. Comentários à Lei de Sociedades Anônimas, v. 3, p. 511. 
A alínea "b" do artigo 168, § $1^{\circ}$, da Lei das Sociedades por Ações dispõe que o estatuto social deverá determinar o órgão competente para deliberar sobre as emissões. Explica Modesto Carvalhosa ${ }^{124}$ que essa competência é excludente, ou seja, caso o estatuto determine ser da administração a competência, caberá unicamente ao conselho de administração deliberar sobre a emissão de novas ações dentro do limite do capital autorizado. Se o estatuto determinar que compete à assembleia geral aprovar este tipo de aumento de capital, a assembleia geral extraordinária será competente para tanto, visto que a matéria em questão não se encontra no rol das matérias ordinárias do artigo $132^{125}$ da Lei das Sociedades por Ações.

Ainda em relação à determinação do órgão competente para deliberar sobre os aumentos no limite do capital autorizado, a opção mais comum é o conselho de administração. Se o intuito do instituto é que os acionistas antecipadamente aprovem aumentos de capital, não há razão para haver uma nova reunião entre eles para deliberar sobre algo que já anteriormente aprovaram. Além do mais, a sistemática de convocação e instalação das reuniões do conselho de administração é mais simples em comparação à das assembleias gerais, sobretudo se se tratar de companhias abertas na captação de recursos junto ao público investidor ${ }^{126}$.

Deve-se ressaltar que a competência pode ser repartida se devidamente detalhada no estatuto social. José Alexandre Tavares Guerreiro, em seu excelente trabalho intitulado Regime Jurídico do Capital Autorizado, ensina que não existem obstáculos para que o estatuto social institua a assembleia geral como órgão competente para deliberar sobre determinadas matérias concernentes ao capital autorizado e o conselho de administração para outras.

Para tanto, porém, é essencial a discriminação estatutária, precisa e completa. Se, no entanto, a assembleia geral é, pelo estatuto, o único órgão competente, não pode delegar ao conselho de administração qualquer dos poderes, implícitos ou explícitos,

\footnotetext{
124 Cf. CARVAlHOSA, Modesto. Comentários à Lei de Sociedades Anônimas, v. 3, p. 511.

125 “Art. 132. Anualmente, nos 4 (quatro) primeiros meses seguintes ao término do exercício social, deverá haver 1 (uma) assembléia-geral para: I - tomar as contas dos administradores, examinar, discutir e votar as demonstrações financeiras; II - deliberar sobre a destinação do lucro líquido do exercício e a distribuição de dividendos; III - eleger os administradores e os membros do conselho fiscal, quando for o caso; IV - aprovar a correção da expressão monetária do capital social (artigo 167)”. Disponível em: <http://www.planalto.gov.br/ccivil_03/Leis/L6404compilada.htm>. Acesso em: 28 de ago. 2012.

${ }^{126}$ Cf. LUCENA, José Waldecy. Das sociedades anônimas, v. 2, p. 798: “A opção, em companhias de capital autorizado, tem sido obviamente pelo conselho de administração, dada a agilidade que o órgão, ao contrário da burocrática assembleia geral, confere ao aumento de capital, na captação de recursos, seja junto ao público investidor no mercado de capitais, em se tratando de companhia aberta, seja junto a investidores particulares, quando se tratar de companhia fechada”.
} 
inerentes ao funcionamento do sistema de acordo como $\S 1 .^{\circ}$ do art. 168. A competência estatutária decorre da lei e, se a lei permite que seja atribuída privativamente à assembleia geral, por escolha dos acionistas consignada no estatuto, a delegação de poderes se torna automaticamente vedada, aplicando-se à espécie o mesmo princípio do art. $139^{127}$.

Em relação às condições da emissão, o estatuto social pode estabelecer as hipóteses em que as ações serão emitidas. Sempre em vista do interesse da companhia, tais condições devem pautar as solicitações de novos aportes de capital, notadamente quando a competência da deliberação for do conselho de administração ${ }^{128}$. Dentre tais condições, é possível citar, exemplificativamente, a espécie e classe de ações que poderão ser emitidas, os critérios para a fixação do preço de emissão (observados os parâmetros do artigo 170, § $1^{\circ}$, da Lei das Sociedades por Ações), e o intervalo mínimo de tempo entre um aumento de capital e outro $^{129}$.

Por fim, em relação ao direito de preferência, o estatuto deve especificar os casos ou as condições em que os acionistas terão direito de preferência para subscrição, ou os casos de inexistência desse direito. A esse respeito, ressalta-se que, enquanto o direito de preferência é a regra (artigo 109, IV, da Lei das Sociedades por Ações), a inexistência desse direito, aplicável somente se a companhia for aberta, é a exceção, conforme será exposto com detalhes no tópico a seguir.

\section{3.}

\section{Direito de Preferência}

A principal função do direito de preferência é a manutenção da proporção detida pelos acionistas no conjunto de todas as ações de emissão da companhia em que se divide o capital social. Tal prerrogativa garante ao acionista a preservação da porcentagem não só de seus direitos patrimoniais como também de seus direitos políticos na sociedade.

Em regra, nos termos do artigo 109, IV, da Lei das Sociedades por Ações, nem o estatuto social nem a assembleia geral poderão privar o acionista dos direitos de preferência

${ }^{127}$ GUERREIRO, José Alexandre Tavares. Regime jurídico do capital autorizado. São Paulo: Saraiva, 1984. p. 86.

${ }^{128}$ Cf. CARVALHOSA, Modesto. Comentários à Lei de Sociedades Anônimas, v. 3, p. 512.

129 Cf. LAMY FILHO, Alfredo; BULHÕES PEDREIRA, José Luiz. Direito das companhias, p. 1391. 
para subscrição de ações, partes beneficiárias conversíveis em ações, debêntures conversíveis em ações e bônus de subscrição. O próprio legislador, no entanto, incluiu uma ressalva no referido dispositivo legal ao estabelecer que a preferência dos acionistas deve observar o disposto nos artigos 171 e 172 da mesma lei.

Especificamente para as companhias abertas, o estatuto social que contiver autorização para o aumento do capital pode prever a emissão - sem direito de preferência para os antigos acionistas, ou com redução do prazo de que trata o $\S 4^{\circ}$ do artigo $171^{130}$ da Lei das Sociedades por Ações -, de ações e debêntures conversíveis em ações, ou bônus de subscrição, cuja colocação seja feita, nos termos do artigo 172 da referida lei, mediante: (i) venda em bolsa de valores ou subscrição pública; ou (ii) permuta por ações, em oferta pública de aquisição de controle, nos termos dos artigos $257^{131}$ e $263^{132}$.

Cabe salientar, adicionalmente, que não são somente as hipóteses previstas no artigo 172 da Lei das Sociedades por Ações que podem afastar o direito de preferência dos antigos acionistas na subscrição e/ou aquisição de ações. Dispõe o artigo 171, § $3^{\circ}$, da referida lei que

os acionistas terão direito de preferência para subscrição das emissões de debêntures
conversíveis em ações, bônus de subscrição e partes beneficiárias conversíveis em
ações emitidas para alienação onerosa; mas na conversão desses títulos em ações, ou
na outorga e no exercício de opção de compra de ações, não haverá direito de
preferência. (Grifo ausente no original)

Assim, como será exposto adiante, seja no caso de subscrição de novas ações, seja no caso de aquisição de ações mantidas em tesouraria, uma vez que o estatuto social tenha autorizado determinado limite para o capital social da sociedade e que os acionistas tenham

\footnotetext{
130 “Artigo 171. Na proporção do número de ações que possuírem, os acionistas terão preferência para a subscrição do aumento de capital. (...) $\S 4^{\circ}$ - O estatuto ou a assembleia geral fixará prazo de decadência, não inferior a 30 (trinta) dias, para o exercício do direito de preferência”. Disponível em: <http://www.planalto.gov.br/ccivil_03/Leis/L6404compilada.htm>. Acesso em: 28 ago. 2012.

131 “Artigo 257. A oferta pública para aquisição de controle de Companhia aberta somente poderá ser feita com a participação de instituição financeira que garanta o cumprimento das obrigações assumidas pelo ofertante. $\S 1^{\circ}$ Se a oferta contiver permuta, total ou parcial, dos valores mobiliários, somente poderá ser efetuada após prévio registro na Comissão de Valores Mobiliários. § $2^{\circ}$ A oferta deverá ter por objeto ações com direito a voto em número suficiente para assegurar o controle da companhia e será irrevogável. § $3^{\circ}$ Se o ofertante já for titular de ações votantes do capital da companhia, a oferta poderá ter por objeto o número de ações necessário para completar o controle, mas o ofertante deverá fazer prova, perante a Comissão de Valores Mobiliários, das ações de sua propriedade. $\S 4^{\circ}$ A Comissão de Valores Mobiliários poderá expedir normas sobre oferta pública de aquisição de controle”. Disponível em: <http://www.planalto.gov.br/ccivil_03/Leis/L6404compilada.htm>. Acesso em: 28 ago. 2012.

132 “Artigo 263. A Comissão de Valores Mobiliários poderá expedir normas que disciplinem a negociação das ações objeto da oferta durante o seu prazo”. Disponível em: <http://www.planalto.gov.br/ccivil_03/Leis/L6404compilada.htm>. Acesso em: 28 ago. 2012.
} 
aprovado o plano de opção de compra de ações no âmbito da assembleia geral, tais acionistas não terão, por imposição legal, qualquer direito de preferência.

Ressalta-se que a exclusão do direito de preferência ocorre tanto no momento da outorga das opções aos beneficiários do plano, quanto no momento do efetivo exercício das mesmas. Estes diferentes instantes dos planos de opção de compra, bem como outras de suas características serão analisados adiante no presente trabalho.

A referida exclusão, embora implique diminuição da participação dos acionistas no capital social, justifica-se pela vantagem atribuída aos beneficiários do plano de opção ser revertida em maior rentabilidade para a companhia e, consequentemente, para os próprios acionistas. Ademais, estes sofrem apenas a diluição de sua participação acionária; e a opção não gera transferência de valor entre acionistas, mas apenas para administradores, empregados ou prestadores de serviços ${ }^{133}$. O propósito dos planos de opção de compra de ações não é a capitalização da companhia; trata-se, na verdade, de um incentivo de caráter contraprestacional aos serviços prestados por seus beneficiários.

\subsection{MOdalidades Afins de REMUNERAÇão BaSEAda EM AÇões}

Diferentemente do legislador brasileiro, que optou por regular os planos de opção de compra dentro do capítulo sobre o capital autorizado na Lei das Sociedades por Ações, a doutrina norte-americana parte da análise da forma adequada de remuneração de seus administradores e empregados, com especial atenção ao alinhamento de interesses destes com os da companhia.

Nos Estados Unidos, a doutrina procurou identificar os tipos mais comuns de planos existentes a fim de facilitar o estudo e a compreensão da matéria, bem como para diferenciálos de outros institutos e evitar associações indevidas. Steven L. Emanuel, por exemplo, sustenta que as formas de remuneração dos administradores de uma sociedade podem ser agrupadas em três grandes categorias ${ }^{134}$ : (i) os pagamentos habituais (current payments), que incluem os salários e os bônus anuais; (ii) os planos de incentivo baseados em ações; e (iii) os

133 Cf. LAMY FILHO, Alfredo; BULHÕES PEDREIRA, José Luiz. Direito das companhias, p. 1428.

134 Cf. EMANUEL, Steven L. Corporations. 4. ed. Nova Iorque: Aspen Law \& Business, 2009. 
planos de pensão e outras formas correlatas. Tendo em vista os fins do presente estudo, serão analisadas apenas as características dos planos de incentivo baseados em ações.

Segundo o referido autor, as sociedades, especialmente as companhias abertas, possuem a grande preocupação de que seus administradores - os quais recebem apenas um salário mensal e, eventualmente, um bônus anual - atuem tendo em vista somente efeitos mais imediatos, sem visar à prosperidade da sociedade a longo prazo (conforme os conflitos de agência analisados anteriormente).

De forma a levar esses executivos a pensarem e agirem em conformidade com os interesses dos acionistas - ou seja, alinhando interesses -, grande parte das companhias concedem a seus administradores um ou mais tipos de incentivos atrelados de alguma forma ao desempenho das ações da companhia, isto é, ao seu valor de mercado. Conforme esse entendimento, Adriana Andrade e José Paschoal Rosseti ensinam que para melhor alinhamento de interesses, a remuneração dos gestores pode ser vinculada ao desempenho da sociedade de duas formas: (i) bonificações; e (ii) stock options. Segundo os referidos autores, enquanto as bonificações estariam mais relacionadas aos objetivos de curto prazo, por estarem vinculadas ao desempenho financeiro da empresa apurado nos balanços anuais, as stock options teriam objetivos de prazo mais longo ${ }^{135}$.

Assim, para Steven L. Emanuel, quatro modalidades de plano de incentivo de longo prazo baseado em ações podem ser sugeridas: (i) Stock Options; (ii) Restricted Stocks; (iii) Stock Appreciation Rights; e (iv) Phantom Stocks.

A stock option consiste em um direito de adquirir ações de uma companhia no futuro por um preço usualmente determinado na data da outorga da opção. A ideia nesse plano é a de que se o preço das ações da companhia subir (presumidamente graças, em parte, à boa atuação do administrador), o administrador será beneficiado, uma vez que poderá, exercendo a sua opção, adquirir um determinado número de ações pagando um preço inferior àquele de sua cotação no mercado no momento da aquisição. Na sequência, é facultado ao administrador vender as ações recém-adquiridas (ficando, portanto, com a diferença positiva entre o preço de venda e o preço de aquisição) ou manter-se na posse das mesmas, caso acredite que tais

\footnotetext{
${ }^{135}$ Adriana Andrade e José Paschoal Rosseti destacam ainda que "[a] composição dos incentivos de curto prazo com os de maior alcance passa, assim, por modelos mais fundamentados na participação acionária do que nos demonstrativos financeiros anuais. A utilização de planos de incentivo baseados preponderantemente em stock options tem sido bem recebida pelo mercado de capitais, especialmente pelos acionistas institucionais. (...) Nos anos 90, nos Estados Unidos, as bonificações de balanço recuaram e as opções de compra de ações aumentaram, na composição da remuneração dos altos executivos”. ANDRADE, Adriana; ROSSETTI, José Paschoal. Governança Corporativa, p. 239.
} 
ações possam se valorizar ainda mais. Para Emanuel, essa modalidade pode ainda ser dividida em dois tipos - as non-qualified stock options e as incentive stock options, conforme possuam ou não tratamento fiscal diferenciado nos termos da legislação norte-americana aplicável.

As restricted stocks, semelhantes aos procedimentos encontrados nas stock options, são aquelas ações que são outorgadas a administradores e empregados de uma sociedade e sujeitas a uma série de limitações. Como ilustração, Emanuel cita o exemplo de uma opção de compra de 100.000 ações que é concedida a determinado administrador, mas que somente se tornará exercível segundo um cronograma predeterminado e desde que o mesmo continue válido em tal data. No caso mencionado pelo autor, a cada ano somente 10.000 ações tornamse exercíveis, de modo que ao final de 10 anos o administrador em questão poderá fazer jus ao seu direito de adquirir a totalidade das 100.000 ações (lembrando que para tanto ele deve continuar empregado por tal companhia). Como é possível observar, os planos de opção utilizados no Brasil muitas vezes conjugam as duas modalidades acima referidas.

Já o stock appreciation right (SAR) é o direito de ser receber um montante em dinheiro equivalente ao aumento do preço da ação da companhia. Por exemplo, Emanuel afirma que, caso uma ação seja vendida pelo preço de R \$10,00 no dia da outorga de um SAR exercível após dois anos, e o preço da ação em tal data seja de $\mathrm{R} \$ 15,00$, o beneficiário da opção receberá o pagamento em dinheiro de $\mathrm{R} \$ 5,00$, equivalente à diferença entre o preço da ação da companhia na data da outorga da opção e seu preço na data do seu exercício.

Por fim, o autor aponta como última modalidade a phantom stock. Tal modalidade assemelha-se bastante ao SAR acima mencionado, dele se diferenciando pelo fato de que na phantom stock são criadas unidades de valor simulando ações. Assim, a phantom stock é calculada sobre o valor total da ação, e não apenas sobre a diferença equivalente ao aumento do preço da ação, visto que é conferido ao beneficiário do plano os mesmos haveres a que faria jus caso fosse, de fato, possuidor das ações. Também difere das stock options pelo fato de não permitir ao beneficiário a efetiva aquisição das ações da companhia. Luis Manuel Alonso González explica que a phantom stock

(...) consiste en establecer un incentivo salarial cuya cuantía se liga al incremento del valor de las acciones de la compañía, sin que se prevea ningún derecho de adquisición de tales acciones. Está clara la diferencia con las stock options: no habrá adquisición de acciones, luego no habrá rendimiento en especie. La referencia al 
valor de las acciones de la empresa se hace a modo de indexación para fijar un determinado componente salarial. ${ }^{136}$

Sem a pretensão de esgotar as características das stock options no direito norteamericano, a classificação acima mencionada é bastante interessante e serve como parâmetro identificador dos planos de opção de compra, sobretudo para diferenciá-los de outros institutos. Para os fins do disposto na Lei das Sociedades por Ações, por exemplo, as duas últimas modalidades não poderiam ser consideradas um plano de opção de compra de ações stricto sensu, pois afastam o risco de perda por parte do beneficiário da opção (se a cotação das ações subir, o beneficiário ganha; se a cotação descer, o beneficiário não perde). Seriam, portanto, apenas benefícios garantidos ao trabalhador baseados na cotação das ações da companhia - apesar da terminologia empregada, para os fins da Lei das Sociedades por Ações, não se trata de planos de opção de compra de ações. Por outro lado, as duas primeiras modalidades sugeridas por Emanuel poderiam, a princípio, ser adotadas no Brasil desde que os demais requisitos previstos na lei também fossem observados, ou seja, a previsão estatutária, o capital autorizado, a aprovação do plano em assembleia geral, além da outorga a administradores ou empregados, ou a pessoas naturais que prestem serviços à companhia ou a sociedade sob seu controle.

O próximo passo será a análise dos planos de opção de compra no cenário societário brasileiro, a partir do qual se busca delimitar a abrangência e a aplicabilidade dos planos de opção de compra às companhias abertas brasileiras.

\footnotetext{
${ }^{136}$ Em tradução livre: "consiste em estabelecer um incentivo salarial cuja quantia se relaciona ao aumento do valor das ações da companhia, sem a previsão de qualquer direito de aquisição das mesmas. É clara a diferença em relação às stock options: não haverá aquisição de ações, de modo que não haverá rendimentos em espécie. A referência ao valor das ações da sociedade se faz a título de indexação para fixar um determinado componente salarial”. GONZÁLEZ, Luis Manuel Alonso; BONETE, Aurelio Desdentado; LUQUE, Miguel Ángel Limón; ANDRÉS, Aníbal Sánchez. Stock Options, Tres Perspectivas: Mercantil, Laboral y Fiscal. Aranzadi, 2002. p. 116.
} 


\section{SEGUNDA PARTE - OS PLANOS DE OPÇÃO DE COMPRA DE AÇÕES}

$\mathrm{Na}$ primeira parte da presente dissertação, foram apresentados os principais fundamentos para a compreensão e o estudo dos planos de opção de compra de ações. Buscou-se rever as teorias clássicas em relação à estrutura de propriedade da sociedade, à teoria da agência e aos deveres e obrigações dos administradores. A compreensão de tais temas é de fundamental importância para o estudo dos planos de opção de compra de ações, pois esses aspectos estão relacionados à evolução jurídica do instituto ora em análise e oferecem as bases para a atuação e eventual responsabilização dos administradores na aprovação e condução dos planos de opção.

Se o administrador de uma sociedade for remunerado adequadamente, os seus interesses tendem a se alinhar com os da sociedade e, por consequência, os custos de agência (acima analisados) serão menores. Por outro lado, os administradores sempre deverão pautar os seus atos na boa-fé, em atenção aos seus deveres de cuidado, diligência e lealdade. Nesse sentido, os planos de opção de compra de ações surgiram como uma interessante alternativa para alinhar interesses e estimular o desempenho de administradores.

Nesta segunda parte da dissertação pretende-se apresentar as principais características dos planos de opção em vigor no Brasil, dando destaque às estruturas atualmente adotadas pelas sociedades por ações abertas nacionais, sempre sob a ótica do direito societário.

Por fim, ressalta-se que a análise dos planos proposta neste trabalho não é exaustiva, embora vise apresentar um amplo panorama das principais práticas adotadas no contexto da atual regulação. 
O legislador pátrio optou por não definir os planos de opção de compra de ações. Limita-se a Lei das Sociedades por Ações, em seu artigo 168, § $3^{\circ}$, a definir os requisitos para a sua aprovação ${ }^{137}$. Alguns autores procuram definir os planos de opção a partir de algumas de suas características. Alan Greenspan, por exemplo, explica que a stock option é uma concessão dos acionistas para o empregado, ou seja, uma transferência, pela companhia, de parte do valor de mercado das ações possuídas pelos acionistas ${ }^{138}$. Já Kevin J. Murphy, em trabalho sobre a remuneração de executivos, ensina simplesmente que as stock options são contratos por meio dos quais os beneficiários têm direito a adquirir ações por um preço determinado por certo período ${ }^{139}$. Javier Ibáñez Jiménez, por sua vez, explica que os planos de opção têm como função refletir políticas de remuneração variável para exercícios futuros ${ }^{140}$.

\footnotetext{
${ }^{137}$ Mauro Brandão Lopes, ao comentar os planos de opções de compra de ações, afirma que a compreensão do instituto é uma tarefa árdua por não trazer a legislação uma caracterização clara do instituto, ficando a análise de sua natureza e de seu uso limitada a outros institutos. Cf. LOPES, Mauro Brandão. S.A.: Títulos e Contratos Novos. São Paulo: Revista dos Tribunais, 1978. p. 86.

138 "A stock option is a unilateral Grant of value from existing shareholders to an employee. It is a transfer through the corporation of part of the market capitalization owned by existing shareholders. The Grant is made to acquire the services of the employee, and presumably has a value equivalent to the cash or other compensation that would have been required to obtain those services - what economists call the opportunity cost of employing those services. That value is obviously a function of when, and under what conditions, the option can be exercised. To assess the cash equivalent of the option, only the market value of the option at the time of the grant matters. Subsequent changes in the value of the option are not relevant to the exchange of labour services for value received, just as future changes in the purchasing power of cash received for services rendered do not affect the firm's compensation costs”. GREENSPAN, Alan. Stock options and related matters. Revista de Direito Bancário, do Mercado de Capitais e da Arbitragem. São Paulo: Revista dos Tribunais, ano 5, n. 17, p. 13-19, jul./set. 2002. p. 15.

139 "Stock options are contracts which give the recipient the right to buy a share of stock at a pre-specified 'exercise' (or 'strike') price for a pre-specified term. Executive options typically become 'vested' (i.e., exercisable) over time: for example, $25 \%$ might become exercisable in each of the four years following grant. Executive options are non-tradable, and are typically forfeited if the executive leaves the firm before vesting (although 'accelerated vesting' is a commonly negotiated severance arrangement, especially following a change in control)". MURPHY, Kevin J. Executive Compensation. abr. 1998. Disponível em: $<$ http://ssrn.com/abstract=163914>. Acesso em: 30 nov. 2010. p. 16.

140 "Los incentivos opcionales emanan de planes o programas de funcionamiento plurianual cuya función estriba en concretar políticas retributivas previamente diseñadas por (aunque no siempre para) los administradores de las sociedades, en particular las cotizadas, con la idea de reforzar la remuneración variable total obtenida en los
} 
Outras características também auxiliam na distinção deste negócio e na análise de sua natureza jurídica ${ }^{141}$. Primeiramente, a existência de um poder exclusivo de uma das partes. Nesse caso, somente o beneficiário da opção é titular da decisão de contratar um negócio subsequente (a aquisição ou subscrição de ações), permanecendo a companhia outorgante na incerteza e expectativa dessa decisão. Outro ponto essencial é a vinculação da companhia outorgante. Exercido o poder do beneficiário, fica a companhia obrigada a satisfazer tal decisão. Explica Felipe Campana Padin Iglesias que dessa vinculação surgem outros deveres secundários ${ }^{142}$, tais como, no caso dos planos de opção, a emissão de novas ações em quantidade suficiente para atender as opções outorgadas (caso não mantidas em tesouraria). Em decorrência das características acima, extrai-se ainda uma terceira: a instrumentalidade. Trata-se da opção de um instrumento para a realização, ou não, de um negócio futuro, já que, uma vez outorgada a opção, o beneficiário poderá exercê-la, aperfeiçoando o contrato ulterior durante um determinado prazo de vigência. Sem atentar para a técnica jurídica, essas características auxiliam na definição da natureza jurídica das opções outorgadas no âmbito dos planos de opção de compra de ações nos termos previstos na Lei das Sociedades por Ações.

Assim, de uma forma geral, entende-se que, por meio desse negócio jurídico, a companhia outorga a determinados administradores ou empregados, a pessoas que prestem serviços à companhia ou a sociedades sob o seu controle o direito de adquirir ou subscrever ações depois de transcorrido certo período da data da respectiva outorga, por um preço predeterminado ou determinável, obrigando-se a, respectivamente, (i) transferir ações já emitidas e mantidas em tesouraria (consequentemente sem o aumento do número de ações em que se divide o capital social); ou, (ii) observados os limites autorizados, aumentar o capital social com a emissão de novas ações em quantidade suficiente para satisfazer o exercício das opções outorgadas, nos termos de plano aprovado em assembleia geral.

Independentemente das características utilizadas para a definição do termo, os planos de opção de compra de ações sempre se relacionam ao alinhamento de interesses e à motivação dos profissionais que, de alguma forma, prestam serviços àquela determinada sociedade, desencorajando comportamentos oportunistas. Os objetivos de um plano de opções

ejercicios siguientes al primero en que se adopta la política de remuneraciones en cuestión (...)”. JIMÉNEZ, Javier Ibáñez. Stock options: Regulación, economia, política retributiva y debate social. Dykinson, 2000. p. 31.

${ }^{141}$ Cf. IGLESIAS, Felipe Campana Padin. Opção de compra ou venda de ações no direito brasileiro. p. 68 e 69.

${ }_{142}$ Padin cita, entre os chamados "deveres secundários”, o dever de não dispor e cuidar do bem objeto da opção, bem como os deveres de conduta decorrentes do princípio da boa-fé. IGLESIAS, Felipe Campana Padin. Opção de compra ou venda de ações no direito brasileiro, p. 68. 
não se limitam, contudo, aos atuais administradores, empregados e prestadores de serviços de uma sociedade e de seu grupo econômico, mas também a futuros profissionais. Os planos de opção revelam-se não só uma eficiente ferramenta para reter bons profissionais, mas também um ótimo atrativo para trabalhadores bem qualificados que estejam em busca de novas oportunidades profissionais.

Proporcionam, assim, os planos de opção uma enorme motivação para seus empregados e prestadores de serviços, estimulando altos níveis de desempenho. É provável que, quanto mais elevado for o desempenho dos beneficiários de um plano de opção, maiores serão os seus ganhos, uma vez que os resultados da companhia também tendem a ser positivos em virtude da atuação desses profissionais. Ademais, ressalta-se que os planos de opção também podem refletir uma melhor imagem institucional da companhia, o que, em conjunto com a boa atuação de seus administradores e empregados, gera uma valorização das ações de emissão da companhia no mercado.

Não obstante, a falta de definição clara no ordenamento brasileiro gera grande discussão quanto à natureza jurídica não só dos planos de opção, mas também das opções em si consideradas ${ }^{143}$. Com relação a estas, duas grandes correntes podem ser identificadas na doutrina $^{144}$ : (i) aquela que entende as opções como uma manifestação unilateral da vontade; e (ii) aquela que enquadra as opções na categoria dos contratos. A primeira corrente subdividese em duas. Alguns autores costumam assemelhar as opções às propostas irrevogáveis, enquanto outros, às promessas unilaterais de contratar. A segunda corrente, por sua vez, também apresenta ramificações. Parte da doutrina qualifica as opções como contratos sujeitos à condição suspensiva; outra parte, como contratos preliminares unilaterais ou bilaterais; e outros, ainda, como contratos definitivos semicompletos ${ }^{145}$. Há também autores que preferem classificar as opções como um contrato sui generis, tendo em vista suas características próprias. Nenhuma delas, contudo, trata especificamente das opções outorgadas no âmbito dos planos de opção de compra de ações nos moldes da Lei das Sociedades por Ações. Temse que reconhecer, todavia, que algumas classificações guardam similitudes às sugeridas por autores nacionais em relação às opções dos planos de opção, que também possuem natureza

\footnotetext{
143 Cf. SZTAJN, Rachel. Sobre a natureza jurídica das opções negociadas em bolsas. Revista de Direito Mercantil, Industrial, Econômico e Financeiro, São Paulo: Malheiros, n. 105, p. 53-69, 1997. p. 58.

144 A classificação é proposta por Felipe Campana Padin Iglesias. Cf. IGLESIAS, Felipe Campana Padin. Opção de compra ou venda de ações no direito brasileiro. p. 76 e 77.

145 A respeito das diferentes correntes sobre a natureza jurídica das opções, cf. PERES, Tatiana Bonatti. Opção de Compra. Curitiba: Juruá, 2011.
} 
jurídica controversa. Para os fins do presente trabalho, serão apontadas apenas algumas das características daquelas correntes majoritariamente predominantes na doutrina brasileira.

Defendendo a corrente de que se trata de um contrato preliminar, Modesto Carvalhosa afirma ser a opção de compra de ações um pré-contrato celebrado com a companhia, cuja eficácia tem por pressupostos a previsão estatutária e a existência de plano aprovado pela assembleia geral. Afirma ainda tratar-se de uma obrigação de fazer, constituindo uma promessa de alienação cujo conteúdo é prestar uma declaração de vontade $^{146}$.

Por outro lado, Orlando Gomes ${ }^{147}$ defende ser a opção um negócio jurídico bilateral, segundo o qual as partes estipulam que uma delas permanecerá vinculada à própria declaração de vontade enquanto a outra reserva para si a faculdade de aceitá-la, ou não, posteriormente. Continua referido autor afirmando que,

\begin{abstract}
Fixados na função preparatória desse contrato, pretendem alguns escritores paragoná-lo ao contrato preliminar de promessa unilateral. A confusão deve ser repelida, porque, com a opção, uma das partes já está vinculada irrevogavelmente, surgindo a obrigação com a aceitação da outra, que se comprometeu, pela natureza do compromisso, apenas a reproduzir o consentimento como ocorre no compromisso, bilateral e irrevogável, de venda. (...) a opção de compra, compreendendo, como compreende, vinculação irretratável, comporta execução sob forma específica, porque não é necessária uma sentença para vincular o proponente, vinculado que se acha pela sua própria declaração de vontade ${ }^{148}$.
\end{abstract}

Conforme esse último entendimento, afirma Araken de Assis que, enquanto uma das partes já “vende” as ações, a outra ainda não as “compra”, podendo, inclusive, nunca chegar a adquiri-las ou subscrevê-las, conforme o caso $^{149}$. Na opção de compra, portanto, tem-se clara a manifestação de vontade do vendedor em contrato de compra e venda cuja formação depende apenas da manifestação de vontade do comprador.

Ainda nessa mesma linha, Vera Helena de Mello Franco e Rachel Sztajn sustentam que a opção de compra consiste em uma obrigação de fazer, de modo que a ideia de a mesma ser classificada como um contrato preliminar deve ser afastada. Segundo as autoras,

\footnotetext{
146 Cf. CARVALHOSA, Modesto. Comentários à Lei de Sociedades Anônimas, v. 3, p. 515.

147 Cf. GOMES, Orlando. Contratos. 26. ed. Rio de Janeiro: Forense, 2008. p. 515.

148 GOMES, Orlando. Contratos, p. 289 e 290.

149 Explica, ainda, que "[n]ada disto acontece no pré-contrato: na promessa de venda faltam as duas declarações (ou o ato judicial de suprimento da declaração faltante), que constituem, precisamente, o objeto do contrato presente. A opção não contém promessa alguma. Tão-só falta a declaração de vontade reservada para melhor oportunidade. Não exercida a opção, libera-se o figurante que declarou a sua vontade”. ASSIS, Araken de. Comentários ao Código Civil Brasileiro: do direito das obrigações. v. 5. ALVIM, José Manoel de Arruda; ALVIM, Thereza. Rio de Janeiro: Forense, 2007. p. 433.
} 
Na lição da doutrina a opção tem natureza obrigacional, constituindo contrato preliminar, cujo descumprimento poderia ensejar a execução específica nos termos do art. 639 CDC. Ousamos discordar, visto cuidar-se de obrigação de fazer (elevar o capital social e oferecer as ações novas resultantes ou oferecer a venda ações já existentes), razão, pela qual, s.m.j. a questão, também aqui, resolve-se em perdas e $\operatorname{danos}^{150}$.

Assim, conforme mencionado, visto que o Código Civil brasileiro de 2002 admitiu a execução específica do contrato preliminar estipulado sem cláusula de arrependimento ${ }^{151}$, tanto no caso do contrato preliminar quanto no do principal, a inexecução contratual é resolvida em perdas e danos.

Francisco Satiro de Souza Júnior, em excelente trabalho sobre o regime jurídico das opções negociadas em bolsas de valores, ensina que as opções podem ser vistas sob dois prismas $^{152}$ : (i) como direito; e (ii) como negócio jurídico ${ }^{153}$. Segundo o autor, fala-se em “direito de opção” quando existe um direito de exercer uma escolha, aplicável como acessório de uma causa principal. Para ele, a característica da opção de impor a subordinação de uma situação jurídica ao exercício unilateral de uma faculdade garantida aproxima o "direito de opção” dos direitos potestativos, que são invioláveis e têm impossível sua inexecução. Afirma ainda que "independentemente da origem - legislação, convenção das parte ou ato administrativo - o direito de opção deve ser visto como um direito meio ('diritto-mezzo' ou 'droit moyen'), unilateralmente exercido para a formação, extinção ou modificação de direitos" ${ }^{\prime 154}$.

\footnotetext{
${ }^{150}$ MELLO FRANCO, Vera Helena de; SZTAJN, Rachel. Manual de Direito Comercial: sociedade anônima e mercado de valores mobiliários. v. 2. São Paulo: Revista dos Tribunais, 2005. p. 130.

151 "Art. 462. O contrato preliminar, exceto quanto à forma, deve conter todos os requisitos essenciais ao contrato a ser celebrado. Art. 463. Concluído o contrato preliminar, com observância do disposto no artigo antecedente, e desde que dele não conste cláusula de arrependimento, qualquer das partes terá o direito de exigir a celebração do definitivo, assinando prazo à outra para que o efetive. Parágrafo único. O contrato preliminar deverá ser levado ao registro competente. Art. 464. Esgotado o prazo, poderá o juiz, a pedido do interessado, suprir a vontade da parte inadimplente, conferindo caráter definitivo ao contrato preliminar, salvo se a isto se opuser a natureza da obrigação. Art. 465. Se o estipulante não der execução ao contrato preliminar, poderá a outra parte considerá-lo desfeito, e pedir perdas e danos. Art. 466. Se a promessa de contrato for unilateral, o credor, sob pena de ficar a mesma sem efeito, deverá manifestar-se no prazo nela previsto, ou, inexistindo este, no que lhe for razoavelmente assinado pelo devedor". Disponível em: <http://www.planalto.gov.br/ccivil_03/Leis/2002/L10406compilada.htm>. Acesso em: 30 ago. 2012.

${ }^{152}$ Ressalta-se que não se pretende no presente trabalho associar as opções negociadas em bolsa àquelas outorgadas no âmbito dos planos de opção. Estas devem observar os requisitos estabelecidos pelo legislador no artigo 168, § $3^{\circ}$, da Lei das Sociedades por Ações; além disso, possuem uma finalidade específica, qual seja, a de incentivar o alinhamento de interesses dos administradores e, por consequência, a atividade fim da companhia. Estas características afastam as opções outorgadas no âmbito dos planos de opção das opções negociadas em bolsa. Não obstante, na classificação sugerida por Francisco Satiro de Souza Júnior há elementos que auxiliam na compreensão do tema, razão pela qual é ora comentada.

${ }_{153}$ SOUZA JR., Francisco Satiro. Regime jurídico das opções negociadas em bolsas de valores, p 34 a 64.

${ }^{154}$ SOUZA JR., Francisco Satiro. Regime jurídico das opções negociadas em bolsas de valores, p. 39.
} 
Por outro lado, a opção também pode ser vista como um negócio complexo. Segundo Satiro, embora apresente inúmeros elementos que a aproximam de institutos como a proposta irrevogável, o contrato condicionado e o compromisso unilateral, alguns de seus aspectos próprios não recomendam sua inclusão em qualquer das citadas classificações. Nesse sentido, conclui o autor que a opção se afasta

(i) da proposta irrevogável, nos termos do art. 1331 do Código Civil Italiano, especialmente por seu caráter bilateral; (ii) da condição suspensiva, por não ter caráter acessório ao negócio final que, diferentemente do que ocorre nos casos de suspensão da eficácia, não está formado por lhe faltar a declaração do titular; e (iii) do compromisso unilateral, porque a simples manifestação do titular é suficiente para concretizar o negócio final, dispensando, assim, nova declaração do lançador. Por outro lado, admite sua concepção sob o caráter oneroso, representado pelo pagamento de prêmio ao lançador como contrapartida à sua subordinação à vontade do titular ${ }^{155}$.

Por fim, o autor sustenta que, em face dos aspectos acima transcritos, as opções são uma espécie de contrato sui generis, criado a partir do exercício da autonomia privada e que apresenta elementos próprios, justificando um regramento distinto.

Desta forma, em vista das várias correntes existentes acerca da matéria, nota-se a complexidade do tema e a falta de consenso na doutrina quanto à natureza jurídica das opções outorgadas no âmbito dos planos de opção de compra de ações.

Já antecipando em parte as conclusões do presente trabalho, tendo em vista as peculiaridades próprias dos planos de opção de compra de ações, é também possível preferir a conceituação das opções outorgadas no âmbito dos mesmos como contrato sui generis. Em cada uma das fases dos planos de opção de compra, como adiante analisadas na presente dissertação, as partes são vinculadas por diferentes negócios jurídicos autônomos, cada qual realizado de um modo diferente. Assim, em cada momento, tanto companhia quanto beneficiários são guiados por interesses e objetivos autônomos e distintos, razão pela qual a busca do alinhamento é tão desejada, em consonância à teoria da agência acima analisada.

\subsubsection{Natureza Salarial $x$ Natureza Comercial}

Assumida a natureza contratual dos stock option plans, também é muito discutido na doutrina e jurisprudência se a natureza jurídica das obrigações assumidas no âmbito das stock

${ }^{155}$ SOUZA JR., Francisco Satiro. Regime jurídico das opções negociadas em bolsas de valores, p. 160. 
options são de natureza trabalhista, mais especificamente de natureza salarial, ou comercial, em razão do seu caráter contraprestacional e das características dos possíveis beneficiários dos planos de opção de compra de ações (administradores, empregados ou pessoas naturais que prestem serviços à companhia ou a sociedade sob seu controle).

Essa questão é extremamente relevante tendo em vista que, caso se trate de natureza salarial (sendo, portanto, incluídos os planos de opção no conceito amplo de salário), é necessária a inclusão dos montantes equivalentes às opções na base de cálculo de todos os direitos decorrentes da relação de emprego previstos no ordenamento, sejam eles de ordem trabalhista, previdenciária ou tributária ${ }^{156}$. Sobre o tema da natureza mercantil ou trabalhista, pelo fato de a jurisprudência ainda não apresentar opinião unânime sobre o tema, surge considerável limitar à estruturação de planos de opção: “a eventual e errônea configuração da natureza salarial do incentivo lhe retiraria a razão de ser, em vista da eliminação das vantagens pelas quais foi inicialmente concebido" ${ }^{157}$.

Ainda em relação ao tema, é possível afirmar que corrobora para a defesa da corrente que sustenta a natureza comercial dos planos de opção de compra de ações o fato de que a faculdade do beneficiário de exercer ou não a opção de compra não está associada unicamente aos serviços prestados por ele à sociedade, mas sim aos resultados do desempenho de toda uma coletividade. Caso o beneficiário tenha apresentado um ótimo desempenho pessoal, mas as ações da companhia tenham se desvalorizado ao longo do período até a data em que o exercício da opção se tornou possível, ele poderá não exercer a sua opção. Por outro lado, caso tenha tido um desempenho aquém do esperado, mas a companhia tenha obtido bons resultados, com a consequente valorização de suas ações, o beneficiário poderá exercer suas opções auferindo, assim, vantagens patrimoniais. São os riscos que correm tanto a companhia quanto o beneficiário.

Ademais, não só a onerosidade que a opção representa para o beneficiário, como também a possibilidade de o beneficiário do plano não auferir vantagem patrimonial alguma,

\footnotetext{
${ }^{156}$ Nesse sentido, Paulo Cezar Aragão e Daniela Soares afirmam que, “[e]m caso de reconhecimento da natureza salarial dos planos de opção, os eventuais ganhos auferidos pelo empregado integrariam o cálculo de benefícios trabalhistas, como gratificação natalina, abono de férias, horas extras, descanso remunerado, bem como contribuições previdenciárias e ao Fundo de Garantia por Tempo de Serviço. Há, ainda, os impactos tributários para o beneficiário, uma vez que a integralidade dos valores recebidos estaria sujeita à tributação sobre a renda proveniente do salário, à alíquota progressiva de até 27,5\% (em oposição aos usuais 15\% aplicados apenas sobre o eventual ganho de capital auferido pelo beneficiário quando da alienação das ações adquiridas em virtude do plano de opções)”. ARAGÃO, Paulo Cezar; SOARES, Daniela. Opções de Compra de Ações, p. 171.

157 ARAGÃO, Paulo Cezar; SOARES, Daniela. Opções de Compra de Ações, p. 171.
} 
afasta o entendimento de que as stock options se enquadrariam no conceito de salário ${ }^{158}$ para os fins trabalhistas. Nessa linha, a justificativa do projeto de lei $n^{\circ} 7.387 / 2010$, do deputado Marco Aurélio Ubiali, afirma que

para que fique indubitavelmente definido que o fruto do contrato de opção de compra de ações não corresponde a verba salarial, deve estar sempre presente o caráter mercantil, que sucumbiria se o empregador garantisse o lucro no exercício da compra das ações e eliminasse o risco característico do mercado de capitais.

Para Paul Andreassen, a ideia do risco normalmente relaciona-se à possibilidade de sofrer perdas ${ }^{159}$. Se o risco está atrelado às opções de compra (um negócio futuro e incerto), então como "pagar” o salário de um determinado funcionário se tal salário pudesse representar um prejuízo para o funcionário? Esta é a principal característica que afasta a natureza salarial das opções de compra de ações. Assim, se esta característica de fato não for contestada, não há o que se falar em salário (e, por consequência, em natureza salarial). Se, por outro lado, o risco for mitigado, não há que se falar em opção de compra de ações. Se um determinado mecanismo de remuneração variável baseada em ações afasta a possibilidade de o beneficiário sofrer perdas, conforme aqueles apontados acima, stricto sensu, não se trata de planos de opção de compra de ações nos termos da legislação brasileira aplicável.

Assim, resumidamente, contribuem para o afastamento do entendimento em favor da natureza salarial das stock options a onerosidade para o beneficiário (é necessário que este desembolse um determinado montante para que possa exercer o seu direito), a expectativa de direito (o empregado pode ou não exercer o seu direito), o risco de ser auferido uma perda (uma vez exercida a opção, é possível que o valor resultante da venda da ação seja inferior àquele de aquisição), o fato de que eventuais resultados não estão diretamente relacionados aos serviços pessoais prestados, mas sim aos de uma coletividade, o fato de que não há nos ganhos auferidos pelos beneficiários, a ausência da habitualidade referida na legislação trabalhista, entre outros aspectos. Acrescenta-se, ainda, que a aquisição de ações pelo

\footnotetext{
${ }^{158}$ Segundo Amauri Mascaro Nascimento, "[s]alário é o conjunto de percepções econômicas devidas pelo empregador ao empregado não só como contraprestação do trabalho, mas, também, pelos períodos em que estiver à disposição daquele aguardando ordens, pelos descansos remunerados, pelas interrupções do contrato de trabalho ou por força de lei. Não tem natureza salarial as indenizações, a participação nos lucros, os benefícios e complementações previdenciárias e os direitos intelectuais”. NASCIMENTO, Amauri Mascaro. Iniciação ao Direito do Trabalho. 33. ed. LTr, 2007. p. 332 e 333. Na mesma linha, segundo Regina Maria Vasconcelos Dubugras, relatora do Processo ${ }^{\circ} 00237005620035020442$ (00237200344202005), do Tribunal Regional do Trabalho da $2^{\mathrm{a}}$ Região, "ante a natureza mercantil da stock option é inviável sua integração aos salários". Disponível em: <http://www.trtsp.jus.br/, código do documento 169410>. Acesso em: 07 set. 2012. Recurso Ordinário em Rito Sumário, Origem: $2^{\text {a }}$ Vara do Trabalho de Santos, Data da publicação: 9 de junho de 2011.

${ }_{159}$ Cf. ANDREASSEN, Paul. The Psychology of Risk. Working paper 87, mar. 1993. Disponível em: $<$ www.levyinstitute.org/pubs/wp/87.pdf>. Acesso em: 07 set. 2012.
} 
beneficiário não altera a natureza jurídica do seu contrato de trabalho. Segundo Carla Lobo Olim Marote, trata-se apenas de uma fórmula de participação do trabalhador na vida e no desenvolvimento da empresa ${ }^{160}$. A autora, de forma sistemática, sugere a realização de três perguntas para a investigação de eventual natureza salarial dos ganhos resultantes da opção de compra de ações: (i) se a vantagem financeira é paga pelo empregador; (ii) se advém da contraprestação do contrato de trabalho; e (iii) se é desprovida de caráter aleatório, pois não cabe ao empregado a assunção dos riscos do negócio. A resposta negativa a tais indagações desqualifica os planos de opção de compra de ações como sendo salário ${ }^{161}$.

Priscila M. P. Corrêa da Fonseca, por sua vez, também defendendo que o lucro auferido com a venda das ações oriundas dos planos de opção de compra não integra o salário do empregado, aponta três diferentes razões para que assim não o seja: (i) o caráter aleatório dos planos, incompatível, portanto, com a periodicidade da remuneração paga ao empregado; (ii) a onerosidade envolvendo a aquisição das ações, uma vez que a participação no capital da companhia não é gratuitamente recebida pelo empregado; e (iii) o risco típico de uma operação de mercado, tendo em vista que, com a alienação das ações, o empregado poderá ter prejuízos $^{162}$.

Já Sérgio Pinto Martins sustenta que o direito de opção não se enquadra no disposto no artigo 457, $\S 1^{\circ}$, da CLT, pois não corresponde a nenhuma das hipóteses ali previstas, bem como envolve fatores aleatórios à companhia, ou seja, a valorização das ações no mercado. Acrescenta, ainda, que não se trata (i) de participação nos lucros, tendo em vista que a questão não decorre da existência de lucros, mas sim da valorização das ações do empregador; ou (ii) de participação nos resultados, pois não existe uma meta a ser obtida pelo desempenho pessoal do empregado, mas sim um resultado da produtividade da empresa em si ${ }^{163}$.

Roberto Quiroga Mosqueira e Maria Isabel Tostes da Costa Bueno sustentam que os bens e direitos adquiridos pelos beneficiários dos planos de opção de compra de ações não devem ser tratados como remuneração, mas sim como operações de compra e venda de ações, razão pela qual não há impactos trabalhistas, previdenciários ou tributários, com exceção da incidência do imposto de renda sobre eventual ganho apurado na alienação futura das ações

\footnotetext{
160 Cf. MAROTE, Carla Lobo Olim. Participação dos empregados no capital da empresa, p. 33.

161 Cf. MAROTE, Carla Lobo Olim. Participação dos empregados no capital da empresa, p. 81-85.

162 Cf. FONSECA, Priscila Maria Pereira Corrêa da. As stock options e seus reflexos na fixação da pensão alimentícia e na partilha de bens. Revista IOB de Direito de Família, Porto Alegre, v. 11, n. 53 p. 67-70, abr./maio 2009. p. 68.

${ }^{163}$ Cf. MARTINS, Sérgio Pinto. Natureza do "stock option” no Direito do Trabalho. Orientador Trabalhista: suplemento de legislação, jurisprudência e doutrina, São Paulo, v. 24, n. 11, p. 3-8, nov. 2005. p. 5.
} 
advindas dos mesmos. Acrescentam, ainda, que algumas características podem demonstrar que os planos não têm natureza salarial, tais como:

(i) a desvinculação entre a concessão de ações ou de opções e as condutas esperadas dos funcionários para o cumprimento de seus contratos de trabalho; (ii) a ausência de gratuidade na concessão e/ou na aquisição de ações e opções; (iii) a evidenciação de que há natureza mercantil na concessão de participação do funcionário nas ações da companhia e não mera premiação financeira; (iv) a assunção de riscos pelos funcionários beneficiários, os quais poderão não auferir benefícios financeiros, ao final, se não houver valorização da empresa; (v) a não possibilidade de que o beneficio consistente na concessão de ações ou opções possa ser transferido a terceiros, ou seja, se não puder ser comercializado pelos beneficiários por certos períodos, limitando a liquidez dos direitos; e/ou (vi) a existência de condições para o gozo do benefício concedido ${ }^{164}$.

No mesmo sentido posiciona-se grande parcela da jurisprudência pátria ${ }^{165}$. Em recente julgado do Tribunal Superior do Trabalho, a Ministra Maria de Assis Calsing assim se manifestou:

\begin{abstract}
Quanto à pretensão de reconhecimento da natureza salarial dos stock options, melhor sorte não assiste ao recorrente. É que ainda que a sua concessão tenha decorrido do contrato de trabalho, trata-se no caso de típico contrato mercantil, o qual quase sempre envolve riscos, podendo o empregado, num tal contexto, auferir lucros ou não com a compra de ações, tudo a depender do mercado. Para o autor auferir algum benefício com o plano que se lhe ofertou, teria que pagar o preço estipulado, donde o seu caráter oneroso, a afastar a suposta natureza de contraprestação pelos seus serviços, além de inviabilizar a pretensão de reconhecimento da natureza de prêmio do plano de compra de ações ${ }^{166}$.
\end{abstract}

O Tribunal Regional do Trabalho da $2^{\mathrm{a}}$ Região também majoritariamente entendeu que os planos de opção de compra de ações não têm natureza salarial:

\footnotetext{
164 MOSQUEIRA, Roberto Quiroga; BUENO, Maria Isabel Tostes da Costa. Questões atinentes à Remuneração de Administradores: Bônus, Participação nos Lucros e Stock Options. In: ROCHA, Valdir de Oliveira (Coord.). Grandes questões atuais do direito tributário, vol. 14. São Paulo: Dialética, 2010. p. 322-323.

165 Cf., também, BRASIL. Tribunal Regional do Trabalho - $15^{a}$ Região. Recurso Ordinário. Processo n. 021252007-109-15-00-2. Relator: Luiz Antonio Lazarim. Data da publicação: 05 dez. 2008; Tribunal Regional do Trabalho - 10a Região. Recurso Ordinário. Processo n. 00572200701710000. Relator: João Amílcar. Data da publicação: 27 jun. 2008; ___. Tribunal Regional do Trabalho - 15a Região. Recurso Ordinário. Processo n. 00387200304515857. Relator: Ricardo Regis Laraia. Data da publicação: 13 jul. 2007; Tribunal Regional do Trabalho - $2^{\text {a }}$ Região. Recurso Ordinário. Processo n. 20010255561. Acórdão nº 20030145141. Rel. Sérgio Pinto Martins. Data do julgamento: 18 mar. 2003; Tribunal Regional do Trabalho - 2a Região. Recurso Ordinário n. 20030636234; Rel. Juíza Anelia Li Chum Data da publicação: 05 dez. 03.

166 BRASIL. Tribunal Superior do Trabalho. $4^{\text {a }}$ Turma. Agravo de Instrumento em Recurso de Revista n. 193300-69.2010.5.03.0000. Data de Julgamento: 29 fev. 2012. Relatora: Min. Maria de Assis Calsing. Diário Eletrônico de Justiça do Trabalho: 02 mar. 2012.
} 
EMENTA: Stock option plan. Natureza comercial. O exercício da opção de compra de ações pelo empregado envolve riscos, pois ele tanto poderá ganhar como perder na operação. Trata-se, portanto, de operação financeira no mercado de ações e não de salário. Não há pagamento pelo empregador ao empregado em decorrência da prestação de serviços, mas risco do negócio. Logo, não pode ser considerada salarial a prestação ${ }^{167}$.

EMENTA. "STOCK OPTIONS”. INCENTIVO AO EMPREGADO. CARÁTER NÃO SALARIAL. Tratando-se as denominadas "stock options" de incentivo ao empregado no desenvolvimento de seus misteres, condicionado, porém, a regras estabelecidas e não sendo gratuito, visto que sujeito a preço, embora com desconto, tem-se que não guardam tais opções de compra de ações da empresa caráter salarial. Recurso Ordinário obreiro a que se nega provimento, no aspecto ${ }^{168}$.

Apesar das denominadas opções de ações serem pactuadas tendo em conta um contrato de trabalho e com natureza de contraprestação, afastam-se da conceituação de salário e dos efeitos de tal enquadramento, porque o empregado livremente adquire as ações sujeitando-se aos riscos de sua valorização ou desvalorização no mercado financeiro e isso, sem qualquer dúvida, implica risco, assumido expressamente pelo alto empregado quando adere ao plano de opções de ações. Caracteriza-se, nos ensinamentos da doutrina, em negócio jurídico de natureza comercial e, por isso, o alto empregado assume o risco da flutuação do valor das ações $^{169}$.

Tanto diferem da natureza salarial que alguns planos expressamente preveem tratamento diferenciado para trabalhadores em situação análoga, algo totalmente inaceitável sob a ótica trabalhista. Como exemplo, prevê o plano da Embraer:

2.3. No exercício de sua competência, o CA [conselho de administração] estará sujeito apenas aos limites estabelecidos na lei, no Estatuto Social da Companhia e no Programa, ficando claro que o CA pode tratar de maneira diferenciada Participantes que se encontrem em situação similar, não estando obrigado, por qualquer regra de isonomia ou analogia, a estender, a outros Participantes, qualquer condição ou deliberação que entenda aplicável apenas a um ou mais Participantes determinados $^{170}$.

Adicionalmente, esclarecem que o plano não garante qualquer vínculo com a sociedade, como no caso do plano da LPS Brasil:

Permanência no Emprego ou Cargo. Nenhuma disposição do Plano conferirá direitos aos Participantes relativos à garantia de permanência como empregado ou prestador

167 BRASIL. Tribunal Regional do Trabalho - 2a Região. Acórdão n. 20030145141. Recurso Ordinário n. 20010255561. Relator: Sérgio Pinto Martins. 2001. Diário Oficial de Justiça: 08 abr. 2003.

168 BRASIL. Tribunal Regional do Trabalho - 2 ${ }^{\text {a }}$ Região. Acórdão n. 20030636234. Recurso Ordinário n. 42364. Processo n. 42364-2002-902-02-00. Relatora: Anelia Li Chum. 2002. Diário Oficial de Justiça: 05 dez. 2003.

169 BRASIL. Tribunal Regional do Trabalho - 2ª Região. Recurso Ordinário. Processo n. 02707200604102009. Relatora: Maria Aparecida Duenhas. 2003. Diário Oficial de Justiça: 31 mar. 2009.

${ }^{170}$ Conforme ata da Assembleia Geral Extraordinária da Embraer S.A., realizada em 19 de abril de 2010. Disponível em: <www.cvm.gov.br>. Acesso em: 9 set. 2012. 
de serviços da Companhia ou de suas controladas ou interferirá de qualquer modo com o direito da Companhia e de suas controladas, sujeito às condições legais e àquelas do contrato de trabalho ou do contrato de prestação de serviços, conforme o caso, de rescindir a qualquer tempo o relacionamento com o Participante. Adicionalmente, nenhuma disposição do Plano conferirá a qualquer titular de uma opção direitos concernentes à sua permanência até o término do seu mandato como diretor ou membro do Conselho de Administração, ou interferirá de qualquer modo com o direito da Companhia ou de suas controladas em destituí-lo(a), nem assegurará o direito à sua reeleição para o cargo ${ }^{171}$.

Dessa forma, defende-se a natureza contratual e mercantil (não salarial) dos planos de opção de compra de ações. Estes, de forma geral, garantem aos beneficiários do plano o direito de participação na valorização futura da sociedade, pelo qual lhes é outorgado o direito de subscrever ou adquirir um determinado número de ações, após certo período de tempo, por um montante previamente determinado ou calculável. Passa-se agora à apreciação sobre como esse contrato é regido pela legislação brasileira aplicável.

5.2.

CONTEXTUALIZAÇÃo NORMATIVA

Os stock options plans são previstos, mesmo que de forma bastante discreta, na Lei das Sociedades por Ações. Dispõe seu artigo 168, § $3^{\circ}$, que o estatuto social pode prever que a companhia, dentro do limite de capital autorizado e de acordo com o plano aprovado pela assembleia geral, outorgue opção de compra de ações a seus administradores ou empregados, ou a pessoas naturais que prestem serviços à companhia ou a sociedade sob seu controle:

Art. 168. O estatuto pode conter autorização para aumento do capital social independentemente de reforma estatutária.

(...)

$\S 3^{\circ} \mathrm{O}$ estatuto pode prever que a companhia, dentro do limite de capital autorizado, e de acordo com plano aprovado pela assembléia-geral, outorgue opção de compra de ações a seus administradores ou empregados, ou a pessoas naturais que prestem serviços à companhia ou a sociedade sob seu controle.

Assim, pela interpretação literal do artigo 168 da Lei das Sociedades por Ações, nota-se que a legislação vigente aplicável às sociedades anônimas brasileiras prevê alguns

171 Conforme ata da Assembleia Geral Extraordinária da LPS Brasil - Consultoria de Imóveis S.A., realizada em 7 de novembro de 2006. Disponível em: <www.cvm.gov.br>. Acesso em: 9 set. 2012. 
requisitos para implementação dos planos de opção de compra, quais sejam: (i) a previsão expressa no estatuto social da companhia; (ii) a existência de e respeito aos limites do capital autorizado; e (iii) a aprovação pelos acionistas em assembleia geral.

É interessante analisar a exposição de motivos da Lei das Sociedades por Ações, que assim justificou o referido artigo (na redação original da lei, artigo 169):

\begin{abstract}
O artigo 169 mantém a inovação introduzida pela Lei ${ }^{\circ} 4.728$, ao admitir que o estatuto social, além de fixar o montante do capital social, estabeleça limite de capital autorizado, dentro do qual a Assembléia Geral ou o Conselho de Administração pode deliberar aumento do capital social, independentemente de reforma estatutária. O capital autorizado, quando fixado em moeda, será corrigido anualmente, para que se mantenha em termos de moeda de mesmo poder aquisitivo $\left(\S 2^{\circ}\right)$. O $\S 3^{\circ}$ do artigo 169 reproduz norma do artigo 48 da Lei $n^{\circ} 4.728$, que regula opção contratual para subscrição de ações, outorgada a administradores, empregados ou pessoas que prestem serviços à companhia. (Grifos ausentes no original)
\end{abstract}

Diferentemente da justificativa apresentada acima, Fran Martins entende que o $\S 3^{\circ}$ do artigo 168 da Lei das S.A. limitou o disposto no referido artigo 48 da Lei ${ }^{\circ} 4.728 / 65^{172}$, que, segundo tal autor, transpunha para o direito pátrio o stock purchase warrant do direito norte-americano ${ }^{173-174}$. Portanto, segundo a exposição de motivos da própria lei, enquanto o

\footnotetext{
172 Artigo 48 da Lei $\mathrm{n}^{\circ}$ 4.728/65: "Nas condições previstas no estatuto, ou aprovadas pela assembléia geral, a sociedade poderá assegurar opções para a subscrição futura de ações do capital autorizado”. Disponível em: <http://www.planalto.gov.br/ccivil_03/Leis/L4728.htm>. Acesso em: 07 set. 2012.

${ }^{173}$ Defende Fran Martins que "não tem razão a Exposição de Motivos quando diz que 'o $\$ 3^{\circ}$ do art. 169 (atualmente 168) reproduz a norma do art. 48 da Lei $n^{\circ} 4.728$, que regula opção contratual para subscrição de ações, outorgada a administradores, empregados ou pessoas que prestem serviços à companhia'. Realmente, o $\S 3^{\circ}$ do atual art. 168 regula essa opção a ser outorgada pela companhia como compensação ou incentivo aos seus empregados ou pessoas que lhe prestem serviços; entretanto, se a fonte desse dispositivo foi o art. 48 da Lei ${ }^{\circ}$ 4.728, essa foi uma fonte indireta, pois aquele inciso legal não se refere a empregados ou pessoas que prestem serviços à sociedade, mas a opções que poderão ser dadas pela companhia a quaisquer pessoas que desejem adquirir o direito de subscrever futuramente ações da sociedade. Divergem, pois, os dois direitos, o que só é outorgado aos empregados ou pessoas que prestem serviços à sociedade (opção da compra de ações) e o de que pode gozar qualquer pessoa que adquira o título que o encerra (bônus de subscrição)". MARTINS, Fran. Comentários à lei das sociedades anônimas: lei no 6.404, de 15 de dezembro de 1976. v. 2. t. II - artigos 165 a 205. Rio de Janeiro: Forense, 1978. p. 475 e 476.

${ }^{174}$ Contemporâneas à Lei ${ }^{\circ}$ 4.728/65, é possível também identificar semelhanças nas chamadas "ações de trabalho", objeto do projeto de lei $n^{\circ}$ 219/1963. Criadas na França, na década de 1910, como uma forma diferenciada de constituição de sociedades anônimas (a então denominada "sociedade anônima com participação obreira”), as ações de trabalho asseguravam aos empregados da companhia direitos de distribuição de dividendos iguais aos conferidos às ações de capital. No entanto, eram intransferíveis, inalienáveis e de propriedade comum de todos os trabalhadores da empresa. Cf. MAROTE, Carla Lobo Olim. Participação dos empregados no capital da empresa, p. 7. Apesar de nítidas as diferenças de tais ações de trabalho em relação aos atuais planos de opção de compra de ações, a ideia de participação societária por funcionários e de repartição do sucesso empresarial pode ser identificada. No Brasil, as ações do trabalho foram objeto do projeto de lei no 219/1963 do Sr. Juarez Távora. Segundo Távora, com a aquisição de tais ações seria facilitada a participação de empregados na copropriedade e na congestão de empresas, democratizando-as. Porém, tal projeto foi arquivado sem nunca no Brasil tais ações terem sido utilizadas (situação semelhante ao insucesso da lei francesa). A seguir, texto do referido projeto de lei extraído do Diário do Comércio Nacional (Seção I), datado de $1^{\circ}$ de maio de 1963, p. 1941: “Art. $1^{\circ}$. Fica criada nas Sociedades Anônimas, entre as ações comuns ou ordinárias, a classe especial de
} 
artigo que teria sido utilizado como parâmetro para a atual redação do artigo 168 tinha como beneficiários uma universalidade mais ampla (“quaisquer pessoas”), o atual dispositivo limita a abrangência dos planos de opção, restringindo a "administradores, empregados ou pessoas que prestem serviços à companhia” a possibilidade de serem beneficiados.

Sobre o warrant norte-americano, cumpre observar que o mesmo foi criado após a quebra da bolsa de Nova Iorque em 1929, por meio da entrada em vigor dos acts de 1933 e 1934. Tinha como objetivo a aquisição ou subscrição de ações de emissão da própria companhia ou de companhia do mesmo grupo ${ }^{175}$, razão pela qual a doutrina os aponta como os precursores das opções brasileiras outorgadas no âmbito dos planos de opção de compra.

É interessante notar, ainda, que o antigo artigo 48 da Lei ${ }^{\circ}$ 4.728/65 utilizava o verbo “subscrever” (“opções para a subscrição futura de ações”), enquanto que artigo 168 da atual Lei das Sociedades por Ações emprega o verbo “comprar” (“outorgue opção de compra de ações”). Nítidas são as diferenças entre esses termos no direito societário. Sem adentrar em detalhes na matéria da subscrição do capital social - o que desviaria o foco da presente dissertação -, resumidamente é possível afirmar que, quando ocorre emissão de novas ações por uma sociedade, estas são subscritas (e posteriormente integralizadas) por um alguém que se torna titular das mesmas, passando a compor o quadro acionário ou aumentando sua participação na companhia. Por outro lado, a “compra” de ações de uma companhia está relacionada à ideia de aquisição de ações já existentes, isto é, ações que foram emitidas em momento anterior ao da aquisição em questão.

Estaria, assim, o artigo 168, $\S 3^{\circ}$, da Lei das Sociedades por Ações se referindo apenas à aquisição de ações já existentes (mantidas em tesouraria, por exemplo)? Parece ser

\footnotetext{
'ações do trabalho'. $\S 1^{\circ}$. As ações do trabalho serão obrigatoriamente nominativas e terão todos os direitos ou vantagens das ações comuns ou ordinárias. $\S 2^{\circ}$. Os subscritores das ações do trabalho serão, obrigatória e exclusivamente, pessoas físicas que prestam serviços remunerados de natureza não eventual à empresa. $\S 3^{\circ}$. As ações do trabalho terão as seguintes limitações à livre circulação: a) O empregado só poderá vender ações do trabalho à empresa e pelo valor nominal; b) o empregado demitido terá garantia de compra de suas ações do trabalho, pelo valor nominal, assegurado pela própria empresa, para pagamento dentro de 120 (cento e vinte) dias de sua demissão; c) o empregado demitido, aposentado ou licenciado perderá o direito de voto nas decisões das Assembléias, ficando respeitadas as demais vantagens das ações. Tal critério se aplicará também nos casos em que as ações do trabalho passarem para propriedade de herdeiros. §4 . Provar-se-á relação empregatícia pelos meios permitidos pela Consolidação das Leis do Trabalho. $§ 5^{\circ}$. Para os diretores de empresa a relação empregatícia se estenderá pelo mandato para que tenham sido eleitos. $\S 6^{\circ}$. São nulas de pleno direito as subscrições de ações do trabalho feitas em desacordo com as disposições dos parágrafos anteriores. Art. $2^{\circ}$. A empresa poderá negociar as próprias ações do trabalho diretamente, pelo valor nominal mantendo-as em seu poder, sem direito a voto, até a primeira Assembleia Geral que se realizar. Art. $3^{\circ}$. Essa lei entrará em vigor 30 (trinta) dias depois de sua publicação no Diário Oficial da União. Art. $4^{\circ}$. Revogam-se as disposições em contrário".

${ }^{175}$ Cf. SOUZA JR., Francisco Satiro. Regime jurídico das opções negociadas em bolsas de valores, p. 81.
} 
negativa a resposta. A interpretação do referido artigo deve ser feita de forma extensiva ${ }^{176}$, de modo a abranger também as ações emitidas pela companhia em caso de aumento do capital social. O intuito da norma é beneficiar com ações determinados administradores, empregados ou prestadores de serviço, independentemente da forma pela qual as ações sejam transferidas para seus respectivos patrimônios. Nesse sentido, explicam Paulo Cezar Aragão e Daniela Soares que, apesar da confusão que possa ser gerada, a amplitude da norma não deve ser restringida:

\begin{abstract}
O termo empregado pela LSA, opção de compra, é diverso daquele constante da Lei $\mathrm{n}^{\circ} 4.728$ e mesmo do trecho citado da Exposição de Motivos, que fazem referência a uma opção de subscrição. Na verdade, qualquer dos dois termos utilizado isoladamente deixa de contemplar o instituto em sua totalidade. A referência à opção de compra poderia fazer crer que se trata apenas de compra, diretamente da companhia, de ações já emitidas e recolhidas à tesouraria. Já a referência à opção de subscrição poderia dar a entender que se trata do direito de subscrever preferencialmente ações novas, emitidas em decorrência de aumento do capital. Em todo caso, hoje já é consolidado o entendimento de que a LSA teve a intenção de que o instituto contemplasse as duas situações $(. . .)^{177}$.
\end{abstract}

É importante destacar que, em vista do entendimento pacífico, referido acima, de que os planos de opção são para a aquisição de ações já existentes (mantidas em tesouraria) ou para a subscrição de novas ações emitidas dentro do limite do capital autorizado, algumas companhias limitam expressamente a abrangência de seus planos. A Ecorodovias, por exemplo, acrescentou em seu plano de opção de compra de ações disposição de forma a excluir a hipótese de emissão de novas ações. Restringiu e condicionou o plano àquelas ações existentes e mantidas em tesouraria: “4.2. Com o propósito de satisfazer o exercício de Opções de compra de ações outorgadas nos termos deste Plano de Opção, a Companhia deverá alienar aos Beneficiários ações de sua emissão mantidas em sua tesouraria”178.

Ainda, referido plano condiciona a adesão ao plano a prévia aceitação, pelos beneficiários, de seus termos e condições mediante a assinatura de termo de adesão, pelo qual declaram e concordam que a companhia em questão poderá não ter à época do exercício a

\footnotetext{
${ }^{176}$ Quanto à interpretação extensiva, Carlos Maximiliano ensina que “[n]as palavras não está a lei e, sim, o arcabouço que envolve o espírito, o princípio nuclear, todo conteúdo da norma. O legislador declara apenas um caso especial; porém a idéia básica deve ser aplicada na íntegra, em todas as hipóteses que na mesma cabem. Para alcançar este objetivo, dilata-se o sentido ordinário dos termos adotados pelo legislador; também se induz de disposições particulares um princípio amplo”. MAXIMILIANO, Carlos. Hermenêutica e Aplicação do Direito. 4. ed. Freitas Bastos, 1947. p. 245.

177 ARAGÃO, Paulo Cezar; SOARES, Daniela. Opções de Compra de Ações, p. 160.

178 Conforme ata da Assembleia Geral Extraordinária da Ecorodovias Infraestrutura e Logística S.A. realizada em 31 de agosto de 2010. Disponível em: <www.cvm.gov.br>. Acesso em: 06 jan. 2012.
} 
quantidade de ações em tesouraria suficientes para satisfazer o exercício das opções outorgadas no âmbito do plano:

6.2. Ao aderirem ao Plano de Opção, os Beneficiários declaram estar cientes e concordarem: (i) que o Plano de Opção é uma forma de investimento no mercado de capitais, sujeito a todos os riscos inerentes a ele, sendo que EcoRodovias não promete ou garante qualquer lucro ou ganho pelo Exercício das Opções; (ii) a Companhia poderá não ter ações em sua tesouraria suficientes para atender as Opções; e/ou (iii) com todas as condições, inclusive mas a tanto não se limitando, de preço, restrições de negociação e as formas de pagamento disponíveis para exercício das Opções ${ }^{179}$.

Não obstante o principal fundamento legal dos planos de opção de compra de ações ser o artigo 168, § 3º da Lei das Sociedades por Ações, outras referências ao instituto podem ser encontradas na mesma lei. O artigo 157 dispõe que o administrador de companhia aberta deve declarar, quando da sua posse, o número de opções de compra de ações de que seja titular, sendo obrigado ainda a revelar as opções que tiver contratado ou exercido no exercício anterior caso solicitado por acionistas que representem $5 \%$ ou mais do capital social ${ }^{180}$. O artigo 166 rege que o capital social pode ser aumentado em razão do exercício de direito conferido por opção de compra de ações ${ }^{181}$. O artigo 171, § $3^{\circ}$, trata do direito de preferência no caso de exercício de opções, acima analisado. Por fim, o artigo 176 estabelece que as notas explicativas das demonstrações financeiras de uma companhia devem indicar as opções de compra de ações outorgadas e exercidas no exercício respectivo ${ }^{182}$.

Diferentemente, portanto, do que se observa em legislações estrangeiras, nota-se que o legislador pátrio preferiu tratar o tema dos planos de opção de compra de ações dentro do

\footnotetext{
179 Conforme ata da Assembleia Geral Extraordinária da Ecorodovias Infraestrutura e Logística S.A. realizada em 31 de agosto de 2010. Disponível em: <www.cvm.gov.br>. Acesso em: 06 jan. 2012.

180 “Art. 157. O administrador de companhia aberta deve declarar, ao firmar o termo de posse, o número de ações, bônus de subscrição, opções de compra de ações e debêntures conversíveis em ações, de emissão da companhia e de sociedades controladas ou do mesmo grupo, de que seja titular. $\S 1^{\circ} \mathrm{O}$ administrador de companhia aberta é obrigado a revelar à assembléia-geral ordinária, a pedido de acionistas que representem 5\% (cinco por cento) ou mais do capital social: (...) (b) as opções de compra de ações que tiver contratado ou

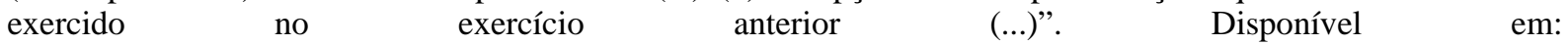
<http://www.planalto.gov.br/ccivil_03/Leis/L6404compilada.htm>. Acesso em: 28 ago. 2012.

181 “Art. 166. O capital social pode ser aumentado: (...) III - por conversão, em ações, de debêntures ou parte beneficiárias e pelo exercício de direitos conferidos por bônus de subscrição, ou de opção de compra de ações (...)’. Disponível em: <http://www.planalto.gov.br/ccivil_03/Leis/L6404compilada.htm>. Acesso em: 28 ago. 2012.

182 “Art. 176. Ao fim de cada exercício social, a diretoria fará elaborar, com base na escrituração mercantil da companhia, as seguintes demonstrações financeiras, que deverão exprimir com clareza a situação do patrimônio da companhia e as mutações ocorridas no exercício: (....) $\S 5^{\circ}$ As notas explicativas devem: (...) IV - indicar: (...) g) as opções de compra de ações outorgadas e exercidas no exercício (...)”. Disponível em: <http://www.planalto.gov.br/ccivil_03/Leis/L6404compilada.htm>. Acesso em: 28 ago. 2012.
} 
capítulo referente ao capital autorizado das companhias, e não dentro do contexto da remuneração de seus administradores.

A CVM, por sua vez, disciplina a matéria por meio de diversos atos esparsos, dentre os quais alguns podem ser destacados. Em ordem cronológica, a primeira menção aos planos de opção de compra de ações é encontrada na Instrução CVM nº 358. A aprovação de plano de outorga de opção de compra de ações é citada como um exemplo de ato ou fato potencialmente relevante pela Instrução $\mathrm{CVM} \mathrm{n}{ }^{\circ} 358^{183}$. Outra questão relevante regulada pela referida instrução diz respeito à negociação privada de ações. Segundo seu artigo 13, antes da

\begin{abstract}
divulgação ao mercado de ato ou fato relevante ocorrido nos negócios da companhia, é vedada a negociação com valores mobiliários de sua emissão, ou a eles referenciados, pela própria companhia aberta, pelos acionistas controladores, diretos ou indiretos, diretores, membros do conselho de administração, do conselho fiscal e de quaisquer órgãos com funções técnicas ou consultivas, criados por disposição estatutária, ou por quem quer que, em virtude de seu cargo, função ou posição na companhia aberta, sua controladora, suas controladas ou coligadas, tenha conhecimento da informação relativa ao ato ou fato relevante ${ }^{184}$.
\end{abstract}

Referida redação, contudo, não deve ser aplicada à aquisição de ações que se encontrem em tesouraria decorrente do exercício de opção de compra de acordo com plano de outorga de opção de compra de ações aprovado em assembleia geral. Nesse sentido, a Instrução CVM no 390 dispõe sobre a negociação, por companhias abertas, de ações de sua própria emissão, mediante operações com opções. Segundo tal ato normativo, a deliberação que aprovar a negociação com opções de venda e compra deve conter, no mínimo, as seguintes informações: (i) a quantidade, por classe e espécie de ações, de opções de compra ou de venda a serem lançadas ou adquiridas, bem como a forma de liquidação e os parâmetros para a determinação das datas de vencimento e dos preços de exercício; (ii) o prazo máximo para a realização das operações, que não poderá exceder seis meses; (iii) a destinação dos recursos captados por meio do lançamento ou da negociação de opções; (iv) as opções já

\footnotetext{
${ }^{183}$ Art. $2^{\circ}$ da Instrução CVM n ${ }^{\circ}$ 358: “Considera-se relevante, para os efeitos desta Instrução, qualquer decisão de acionista controlador, deliberação da assembléia geral ou dos órgãos de administração da companhia aberta, ou qualquer outro ato ou fato de caráter político-administrativo, técnico, negocial ou econômico-financeiro ocorrido ou relacionado aos seus negócios que possa influir de modo ponderável: I - na cotação dos valores mobiliários de emissão da companhia aberta ou a eles referenciados; II - na decisão dos investidores de comprar, vender ou manter aqueles valores mobiliários; III - na decisão dos investidores de exercer quaisquer direitos inerentes à condição de titular de valores mobiliários emitidos pela companhia ou a eles referenciados. Parágrafo único. Observada a definição do caput, são exemplos de ato ou fato potencialmente relevante, dentre outros, os seguintes: (...) XII - aprovação de plano de outorga de opção de compra de ações (...)”. Disponível em: $<$ www.cvm.gov.br>. Acesso em: 05 fev. 2012.

${ }^{184}$ Disponível em: <www.cvm.gov.br>. Acesso em: 05 fev. 2012.
} 
lançadas ou detidas pela companhia; e (v) a declaração, por parte da companhia, de que não há quaisquer fatos relevantes que não tenham sido divulgados. Dessa forma, caso as condições do exercício da opção sejam previamente determinadas e acordadas entre as partes, não haverá qualquer vantagem em razão do momento da divulgação do fato relevante, afastando, assim, eventual uso de informações privilegiadas pelos beneficiários das opções.

O Ofício-Circular/CVM/SEP/Nº1/2005 estabelece que, para facilitar a consulta e o acompanhamento pelo mercado e pela CVM dos planos de opção, uma versão destes deve ser encaminhada à CVM pelo sistema eletrônico de envio de informações periódicas. Ademais, referido ofício-circular dispõe que a política de negociação de valores mobiliários de uma companhia adquire maior relevância caso as companhias adotem programas de incentivo aos seus empregados e executivos, tais como plano de opções de compra. Explica a CVM que

Assim, ao estabelecer normas internas, as companhias definem uma linha de orientação geral, ao mesmo tempo em que deixam claro aos seus investidores que estão atentas à lisura e transparência de operações envolvendo os valores mobiliários de sua emissão, com destaque àquelas de natureza privada. (Item 5.8 do OfícioCircular/CVM/SEP/No01/2005) ${ }^{185}$

A Deliberação da CVM n ${ }^{\circ}$ 562, de 17 de dezembro de 2008, aprovou o Pronunciamento Técnico CPC 10 do Comitê de Pronunciamentos Contábeis, que trata de pagamento baseado em ações. Segundo tal deliberação, a entidade deve divulgar informações que permitam aos usuários das demonstrações contábeis entender a natureza e a extensão de acordos de pagamento baseados em ações que ocorreram durante o período. Para tanto, as informações ${ }^{186}$ sobre as opções devem ser divulgadas em notas explicativas complementares às demonstrações financeiras (art. 176, § 5 , IV, “g” da Lei das Sociedades por Ações).

\footnotetext{
185 Disponível em: <www.cvm.gov.br>. Acesso em: 05 fev. 2012.

186 Entre as informações estão a descrição dos termos gerais do plano e programas, e a quantidade e o preço de exercício médio ponderados das opções outorgadas, exercidas e em aberto no período. Item 45 da referida Deliberação: "Para tornar efetivo o cumprimento do disposto no item anterior, a entidade deve divulgar, no mínimo o que segue: (a) A descrição de cada tipo de acordo de pagamento baseado em ações que vigorou em algum momento do exercício social, incluindo, para cada acordo, os termos e condições gerais, tais como as condições de aquisição, o prazo máximo das opções outorgadas e a forma de liquidação (em dinheiro ou em ações). Quando a entidade tem substancialmente tipos similares de acordos de pagamento baseados em ações, ela pode agregar essa informação, a menos que a divulgação separada para cada acordo seja necessária para atender o princípio contido no item 44; (b) A quantidade e o preço médio ponderado de exercício das opções de ação para cada um dos seguintes grupos de opções: (i) em aberto no início do período; (ii) outorgada durante o período; (iii) perdida durante o período; (iv) exercida durante o período; (v) expirada durante o período; (vi) em aberto no final do período; e (vii) exercível ao final do período; (c) Para as opções de ação exercidas durante o período, o preço médio ponderado das ações na data do exercício. Se opções forem exercidas em base regular durante o período, a entidade pode, em vez disso, divulgar o preço médio ponderado das ações durante o período; (d) Para as opções em aberto ao final do período, deve-se divulgar o valor máximo e mínimo de preço de exercício e a média ponderada do prazo contratual remanescente. Se a diferença entre o preço de exercício
} 
A recente Instrução CVM n ${ }^{\circ} 480$ reformou o procedimento brasileiro de registro de companhias abertas, estabelecendo novas normas para o registro de emissores de valores mobiliários admitidos à negociação em mercados regulamentados de valores mobiliários. Dentre as principais mudanças, ressalta-se a criação do chamado Formulário de Referência, que exige a divulgação de uma série de informações detalhadas sobre a companhia, incluindo informações quanto a riscos de investimento na companhia, atividade desenvolvida, principais acionistas, remuneração, valores mobiliários, entre outras. Para os fins do presente trabalho, destaca-se o item 13.4 do Formulário de Referência:

13.4. Em relação ao plano de remuneração baseado em ações do conselho de administração e da diretoria estatutária, em vigor no último exercício social e previsto para o exercício social corrente, descrever: a) termos e condições gerais; b) principais objetivos do plano; c) forma como o plano contribui para esses objetivos; d) como o plano se insere na política de remuneração do emissor; e) como o plano alinha os interesses dos administradores e do emissor a curto, médio e longo prazo; f) número máximo de ações abrangidas; g) número máximo de opções a serem outorgadas; h) condições de aquisição de ações; i) critérios para fixação do preço de aquisição ou exercício; j) critérios para fixação do prazo de exercício; k) forma de liquidação; l) restrições à transferência das ações; m) critérios e eventos que, quando verificados, ocasionarão a suspensão, alteração ou extinção do plano; e n) efeitos da saída do administrador dos órgãos do emissor sobre seus direitos previstos no plano de remuneração baseado em ações.

Nota-se, portanto, a partir das instruções acima mencionadas, grande preocupação da CVM com a regulação e divulgação de informações relacionadas aos planos de opção de compra de ações. Sobretudo a partir de 2002, foi grande o número de normativos expedidos sobre o tema, o que demonstra a maior relevância do instituto nos últimos anos.

Por fim, devem-se destacar os dois projetos de lei atualmente apensados e em trâmite na Câmara dos Deputados ${ }^{187}$ : (i) o projeto de lei $n^{\circ} 7.387 / 2010$, do deputado Marco Aurélio Ubiali; e (ii) o projeto de lei $n^{\circ} 7.635 / 2010$, do deputado Carlos Gomes Bezerra. O primeiro trata da inclusão do artigo $168-\mathrm{A}^{188}$ na Lei das Sociedades por Ações, para regulamentar as

mínimo e máximo (intervalo) for muito ampla, as opções em aberto devem ser divididas em grupos que sejam significativos para avaliar a quantidade e o prazo em que ações adicionais possam ser emitidas e o numerário que possa ser recebido quando do exercício dessas opções”. Disponível em: <www.cvm.gov.br>. Acesso em: 09 set. 2012.

187 Para detalhes da tramitação, cf. informações disponíveis em: <http://www.camara.gov.br/sileg/default.asp>. Acesso em: 27 mar. 2012.

188 “Artigo 168-A. As sociedades anônimas de capital aberto poderão implementar planos de opções de compra de ações para seus administradores e demais empregados, denominados de 'stock options', da seguinte forma: I - Para os efeitos desta lei, será definido como planos de opção de compra, 'stock options plans', a outorga a um ou mais empregados do direito de comprar, em uma data futura, ações de uma sociedade por um preço especificado ao tempo em que a opção lhes são conferida, e não ao tempo em que as ações são realmente adquiridas. II - Os planos de exercício de opção de compra pelos administradores, denominados de 'stock options', deverão ser limitados a 6\% (seis por cento) do capital social da sociedade anônima de capital aberto 
implementações de planos de opções de compra de ações, pelos administradores e demais
funcionários a título retributivo; e o segundo da inclusão do artigo $458-\mathrm{A}^{189}$ à Consolidação

das Leis do Trabalho - CLT, para também dispor sobre a concessão de stock options.

sediada no Brasil; III - Os planos de trata o inciso acima, para os demais empregados que não ocupam cargo ou função de administradores, deverão ser limitados em $10 \%$ (dez per cento) do capital social da sociedade de capital aberto sediada no Brasil; IV - A Comissão de Valores Mobiliários - CVM, poderá autorizar a elevação ou redução desse critério de percentagem em razão do porte da empresa e do setor econômico onde a empresa atua de forma a satisfazer a retribuição mais favorável aos empregados. V - A Companhia deverá convocar uma assembléia geral de acionistas para a aprovação de forma detalhada, do aduzido plano de opção de compra de ações destinada aos empregados; VI - A Comissão de Valores Mobiliários - CVM, deverá ser comunicada dentro de 30 (trinta) dias corridos da aprovação do plano, com a comunicação a empresa acostará toda a documentação necessária para análise; VII - A Comissão de Valores Mobiliários poderá fazer recomendações dentro de 60 (sessenta) dias após a comunicação a que se refere o inciso anterior ou impedir a implementação do plano e a suspensão ou cancelamento a qualquer momento; VIII - Os referidos planos de opções de compra de ações, não têm caráter ou natureza salarial, e devem ser contratados de forma independente do contrato de trabalho, e o empregado deverá pagar um valor estipulado no plano para exercer a opção, que será contabilizado como receita da empresa. IX - Se a empresa fizer a liquidação do plano de opção de oferta de compra ações em dinheiro ou em quaisquer bens que não sejam ações dela ou da empresa matriz, essa remuneração terá caráter salarial; X - A empresa poderá oferecer a título de incentivo, um desconto de no máximo de 15\% (quinze per cento) do valor no pregão da Bolsa de Valores, Mercadorias e Futuros de São Paulo - BM\&F Bovespa S.A., da ação na data em que a opção for conferida ao empregado, desde que o valor de cada ação não fique inferior ao valor de emissão da mesma; XI - Os planos de opções de compra de ações de que trata este artigo, não poderão ser negociados antes de vencer o seu período de carência integralmente, também conterá no plano um prazo máximo para o exercício da opção de compra por parte do empregado, que será a data da expiração; XII - O empregado somente terá direito para exercer a opção se cumprir integral ou periodicamente a carência, consoante consta no contrato celebrado, perderá esse direito se for demitido com justa causa antes de cumprir cada carência estipulada; Parágrafo único. Se o empregado for demitido sem justa causa 180 (cento e oitenta) dias antes do término do período de carência, terá direito de exercer a opção de compra do plano na proporção que esteve empregado na empresa, afora esta condição perderá o direito de usufruir da opção. XIII - As empresas deverão contabilizar os planos de opções de compra a que se refere este artigo, com a rubrica de Despesa de Plano Retributivo e assim apresentados em suas Demonstrações Financeiras, e seu valor calculado com base no ganho potencial ou esperado, conforme metodologia do modelo PEV - Present Economic Value da Watson Wyatt Wordwille (Valor Presente Atual), adequado à norma internacional IFRS-2 (International Financial Reporting Standard), ou qualquer outra metodologia que vier a ser adotada pela Comissão de Valores Mobiliários - CVM; XIV - A contabilização dessa despesa referida no inciso anterior, deverá ser proporcional e mensal, conforme o período de carência do mencionado plano de opções, na data da outorga, o ajuste pelo valor justo dos títulos patrimoniais; XV - A empresa não poderá reverter a despesa reconhecida no exercício anteriores ou no exercício corrente, em nenhum momento; XVI - Não será permitido nos referidos planos a utilização de qualquer índice de medição histórico ou de metas inflacionárias, apenas as variações das negociações própria das ações da empresa no mercado financeiro, mais precisamente na Bolsa de Valores, Mercadorias e Futuros de São Paulo - BM\&F Bovespa S.A. XVII - As sociedade por cotas de responsabilidade limitada, que são subsidiárias, filiais, sucursais de sociedade de capital aberto no exterior, em que seus administradores e empregados forem contemplados com o referido plano de opções da empresa matriz, deverão observar o que determina esta lei. XVIII - Por se tratar de relação de empregado com empregador, portanto de matéria de índole trabalhista, a Justiça do Trabalho é competente para julgar as questões a respeito, com observância na Constituição Federal, nos artigos 121 a 137 do Código Civil, no artigo $9^{\circ}$ da Consolidação das Leis do Trabalho e demais normas pertinentes. Parágrafo único. A arbitragem é inaplicável ao direito individual do trabalho e se, os serviços forem prestados no Brasil, serão regidos pela lei brasileira”. Disponível em $<$ http://www.camara.gov.br/sileg/default.asp>. Acesso em: 27 mar. 2012.

189 “Art. 458-A - A participação acionária de empregado por meio de Plano de Concessão de Ações sob a modalidade de Opções de Ações (Stock Options) consiste em vantagem contratual de natureza: I - não salarial, quando tratar-se de condição de contrato estabelecida como luvas ou apenas com o objetivo de fidelizar o trabalhador na empresa, sem qualquer conotação de caráter retributivo, e o método de exercício autorizado implicar onerosidade e risco para o empregado; II - salarial, quando, em complementação ao salário fixo contratado, entre outras hipóteses de utilização do plano de opções como estratégia de remuneração variável: a) a concessão do benefício for vinculada diretamente ao desempenho ou a metas de produtividade; b) o método de 
Até agosto de 2012, referidos projetos de lei não tinham sofrido quaisquer emendas e ainda seriam apreciados pelas comissões de trabalho, de administração e serviço público; de desenvolvimento econômico, indústria e comércio; de finanças e tributação; e de constituição e justiça e de cidadania. Muitas alterações, portanto, ainda devem ser realizadas no texto proposto, mas desde já é possível observar a preocupação do legislador com a definição dos planos de opção de compra de ações, bem como com as características que devem ser observadas para caracterizá-los como uma vantagem de natureza contratual.

Especificamente em relação ao texto sugerido para o artigo 168-A da Lei das Sociedades por Ações, dentre outros comentários que, obviamente, devem ser realizados por

exercício autorizado no ato concessivo da premiação não implicar ônus ou risco ao beneficiário. $\S 1^{\circ}$ Consideram-se gratuitos e sem riscos para o empregado, na forma da alínea 'b' do inciso II do caput deste artigo, os modelos de concessão de opções em que: I - as ações são custodiadas ao empregado de forma subsidiada pela empresa, que prefixa o preço em valor simbólico; ou II - são exercidas sem qualquer desembolso financeiro do empregado, por meio de métodos como os de: a) operação casada ou compra e venda no mesmo dia (cash less exercise ou same day sale), na qual a operação de compra e venda é desenvolvida simultaneamente, sendo creditada ao empregado a diferença entre o valor da compra da ação, conforme o preço que lhe for prefixado, e o valor da venda da ação, conforme o preço praticado pelo mercado no momento da negociação; b) venda a descoberto (sell to cover), na qual o custo da opção é coberto com a utilização de parte das ações. $§ 2^{\circ}$ Os ganhos líquidos auferidos dos benefícios de natureza jurídica negocial, previstos no inciso I do caput deste artigo, serão tributados em conformidade com o disposto na Lei n. ${ }^{\circ}$ 9.959, de 27 de janeiro de 2000, para as operações realizadas nas bolsas de valores, ou na legislação que lhe for sucedânea. § $3^{\circ} \mathrm{Na}$ hipótese do inciso II do caput deste artigo, o lucro recebido a esse título: I - constitui base de incidência dos encargos trabalhistas e previdenciários, aplicando-se-lhe o princípio da habitualidade; II - será tributado na fonte, em separado dos demais rendimentos recebidos no mês, como antecipação do imposto de renda devido na declaração de rendimentos da pessoa física, competindo à pessoa jurídica a responsabilidade pela retenção e pelo recolhimento do imposto. $\S 4^{\circ}$ Salvo se estabelecida como condição inerente ao próprio contrato de trabalho, a concessão de Opções de Ações (Stock Options) como ato esporádico de mera liberalidade, ainda que com eventual natureza salarial, não se incorpora ao contrato de trabalho, restringindo-se à sua vigência e objeto. $\S 5^{\circ}$ Após a concessão de Opções de Ações, (Stock Options) salvo disposição mais favorável, o direito ao exercício das opções expira com: I - a renúncia; II - o término da validade estabelecida no ato concessivo do benefício ou na forma do $\S 6^{\circ}$ deste artigo; III - a rescisão do contrato de trabalho, se ainda não vencido o período de carência, nas hipóteses de pedido de demissão e de dispensa por justa causa; $\S 6^{\circ}$ Se a obtenção da condição de elegibilidade das opções concedidas for inviabilizada em face de dispensa arbitrária ou imotivada, o beneficiário poderá exercê-las até trinta dias após vencida a respectiva carência, salvo se o empregador lhe conceder período de validade maior que este. $\S 7^{\circ}$ Vencido o prazo de carência e adquirida a condição de elegibilidade das ações, o direito ao exercício das opções é assegurado inclusive após o falecimento ou a rescisão contratual, independentemente da modalidade e da iniciativa desta, observado o prazo de validade estabelecido no ato concessivo do benefício. $\S 8^{\circ}$ O aviso prévio, mesmo que indenizado, integrará o contrato de trabalho para efeito de contagem do período de carência estabelecido pelo plano de concessão de opções. $\S 9^{\circ}$ Aplica-se o disposto nos $\S \S 5^{\circ}, 6^{\circ}, 7^{\circ}$ e $8^{\circ}$ deste artigo independentemente de as Opções de Ações(Stock Options) serem concedidas com caráter salarial ou como negócio jurídico de natureza comercial, ainda que estabelecido em face do contrato de trabalho, na forma do inciso I do caput deste artigo. § 10 Consideram-se submersas (underwater) as ações cujo valor de mercado estiver abaixo do preço de exercício fixado na concessão das opções. § 11 Quando submersas as ações, na hipótese de o benefício ter sido concedido com caráter retributivo, na forma do inciso II deste artigo: I - compete ao empregador a adoção de medidas alternativas para viabilizar o direito ao exercício das opções concedidas como contraprestação salarial ou premiação, na forma respectiva das alíneas 'a' e 'b’ do inciso II do caput deste artigo; II - considera-se obstativa a dispensa de empregado inviabilizado de exercer o direito das opções concedidas, aplicando-se, conforme o caso, os $\S \S 6^{\circ}$ e $7^{\circ}$, combinados com o inciso I deste parágrafo, todos deste artigo, salvo acordo de indenização compensatória. § 12 A concessão de Opções de Ações (Stock Options) não enseja a aplicação do princípio da isonomia ou da irredutibilidade salarial sob o argumento de prejuízo patrimonial decorrente da volatilidade das ações, ressalvada a hipótese estabelecida no § 11 deste artigo”. Disponível em <http://www.camara.gov.br/sileg/default.asp>. Acesso em: 27 mar. 2012. 
comissões e juristas especializados na elaboração de textos legais, sem a pretensão de esgotar o tema, destacam-se as seguintes considerações, que devem ser expostas por se relacionarem a temas tratados ao longo do presente trabalho ${ }^{190}$.

O caput é restrito e trata somente das sociedades por ações abertas, permanecendo as sociedades por ações fechadas sem qualquer regulamentação específica. Logo no inciso I é sugerida uma definição para o que seriam os planos de opção de compra de ações. Nota-se que o texto legal até então sugerido pecou por limitar os beneficiários dos planos de opção somente aos "empregados" (deixando de fazer referência aos administradores e às pessoas naturais que prestem serviços à companhia ou a sociedade sob o seu controle), bem como não teve a preocupação de tratar das hipóteses de subscrição de novas ações (foi utilizado apenas o verbo “comprar”). Da mesma forma, não foram feitas quaisquer referências a questões relacionadas a pessoalidade, possibilidade de transferência das opções ou determinação de um prazo para o exercício da opção (a expressão “uma data futura” é muito ampla, de modo que prazos demasiadamente longos poderiam vir a ser estabelecidos, vinculando, assim, a companhia à vontade do beneficiário por tempo praticamente indeterminado), entre outros aspectos.

Os incisos II e III tratam do percentual máximo das ações oriundas das opções que podem ser emitidas em virtude dos planos de opção: 6\% para administradores e 10\% para empregados que não ocupam cargo ou função de administradores. Tratar-se-ia de dois planos diferentes em que o percentual máximo de diminuição de participação acionária dos antigos acionistas seria limitado, ao todo, a 16\%? Ou seria apenas um plano com o percentual máximo de 10\%, sendo que desse percentual a participação para administradores estaria limitada a 6\%? A redação é dúbia e dá margem a diferentes interpretações. Ademais, não caberia à própria companhia e aos seus acionistas determinar o grau de diminuição de participação acionária que melhor convém a seus interesses e atividades? Talvez já prevendo a resposta para esta última indagação, no inciso IV o legislador propõe, de forma correta, que a CVM poderá autorizar a alteração das referidas porcentagens em razão do porte da companhia e do setor econômico em que atua de forma a permitir a retribuição mais favorável aos empregados $^{191}$. Não constam do dispositivo, contudo, os procedimentos para a solicitação,

\footnotetext{
${ }^{190}$ Para o texto das referências a seguir indicadas do artigo 168-A do projeto de lei $n^{\circ} 7.387 / 2010$, cf. nota ${ }^{\circ}$ 188 acima.

191 A Instrução CVM no 282, de 26 de julho de 1998, apresenta sistemática semelhante na medida em que fixa escala, em função do valor do capital social, para a adoção do voto múltiplo na eleição de conselheiros de companhias abertas. Quanto maior o capital social, menor é o percentual mínimo exigido para a solicitação do voto múltiplo.
} 
pela companhia, da redução ou do aumento dos percentuais, nem os prazos para a CVM conceder a autorização requerida. Outro ponto relevante consiste no fato de a redação proposta fazer referência ao “capital social” da sociedade. Nesse sentido, a princípio, o legislador preferiu não fazer distinção entre ações ordinárias e ações preferenciais, de modo que, conforme os termos e condições constantes do respectivo plano, o número de opções outorgadas deverá ser limitado ao percentual do número total de ações de emissão da companhia.

Em relação ao inciso V, a aprovação em assembleia geral já é uma das condições para a aprovação do plano, nos termos do artigo 168, § 3º da Lei das Sociedades por Ações, o que torna a inclusão desse mesmo dispositivo no artigo 168-A repetitiva e equivocada. Da mesma forma, a Instrução CVM nº 358 já prevê o dever de divulgar do plano de opção de compra de ações aprovado pelas companhias abertas à CVM e ao mercado (inciso VI do texto proposto para o artigo 168-A).

O inciso VII, por sua vez, estabelece que a CVM poderá propor recomendações, dentro de 60 dias após a comunicação referida no inciso VI, e até mesmo impedir a implementação do plano de opções de determinada companhia, por meio de sua suspensão ou cancelamento a qualquer momento. Tal dispositivo, totalmente discricionário, permitiria uma interferência pública na administração e gerência interna das companhias abertas brasileiras, dando margem, inclusive, para oscilações no preço das ações da companhia em questão, sem mencionar a considerável insegurança jurídica. Além disso, na inércia da CVM durante o referido prazo de 60 dias, estaria o plano automaticamente aprovado? O que fazer com planos aprovados automaticamente que estejam em desacordo com as recomendações da CVM? Durante esse período, a companhia poderia outorgar opções? Se outorgadas as opções e a CVM viesse a fazer recomendações ou suspender ou cancelar o plano, como ficariam os direitos do terceiro (beneficiário) de boa-fé? Faria este jus a indenização por perdas e danos? Neste caso, como calcular tal indenização? Se a indenização for devida, não estaria a companhia afastando o risco inerente ao negócio e, portanto, a natureza mercantil das opções outorgadas no âmbito dos planos de opção? Diversas, portanto, são as questões que podem surgir caso a redação proposta seja aprovada em seus atuais termos ${ }^{192}$.

Os incisos VIII e IX tratam da questão relacionada à caracterização da natureza salarial dos planos de opção, conforme já analisada na presente dissertação. O tema em si é o

\footnotetext{
192 Tais indagações estão baseadas em suposições, visto que a redação sugerida no projeto de lei nº 7.387/2010 sequer foi aprovada. Servem, portanto, como provocação para o estudo do tema.
} 
foco principal do projeto de lei $\mathrm{n}^{0} 7.635 / 2010$, que adota a onerosidade e o risco para o empregado como as principais características para diferenciar o chamado (conforme definido em tal projeto de lei) “plano de opção de ações com natureza salarial” daquele com natureza não salarial.

Destaca-se que a simples denominação de "plano de opção de compra de ações” não pode servir como disfarce de uma distribuição de salário. Salário é salário; e plano de opções de compra de ações é plano de opções de compra de ações, independentemente da nomenclatura utilizada ${ }^{193}$. Se for salário, deve observar toda a legislação pertinente, inclusive de ordem contábil e tributária, sem a necessidade de se criar uma nova figura (o "plano de opção de compra de ações de natureza salarial”). Se o “plano” criado por uma determinada sociedade não se enquadrar na definição e não atender os requisitos de um plano de opção de compra de ações propriamente dito (daí a importância da perfeita compreensão do tema), não se justifica a preocupação com sua regulamentação (visto que a conceitualização de salário já é vastamente abordada pela legislação, doutrina e jurisprudência).

O inciso X regula a questão do preço do exercício da opção de compra de ações por meio da fixação de um percentual máximo de desconto a ser dado sobre o valor de mercado da ação, conforme sua cotação na BM\&FBovespa. Subentende-se, portanto, que o critério do artigo 170, $\S 1^{\circ}$, III (cotação da ação em bolsa de valores) passa a ser obrigatório para a fixação do preço de exercício das opções das companhias abertas e que o valor máximo do desconto concedido pelos acionistas não deve ultrapassar $15 \%$ do valor da ação. Aqui, novamente, a questão da determinação de um percentual fixo para todas as companhias deve ser analisada com cuidado. O "tamanho" do incentivo a ser conferido pela companhia e seus acionistas para o alinhamento de interesses dos beneficiários do plano deve ser analisado caso a caso; caso contrário, corre-se o risco de tornar o plano não vantajoso ou, por outro lado, de instigar condutas abusivas.

Ainda em relação aos dispositivos que tratam de assuntos abordados no presente trabalho, os incisos XI e XII e o parágrafo único do proposto artigo 168-A dizem respeito ao período de carência para o exercício das opções outorgadas no âmbito dos planos de opção de compra. Extrai-se que os planos deverão prever um prazo máximo para o exercício da opção por parte do beneficiário, bem como que estes deverão observar os prazos de carência

193 “Aplicando-se por analogia a regra do art. $4^{\circ}$ da CLT, verificamos que o tributo não é caracterizado pela denominação ou pela destinação legal do produto da sua arrecadação, mas sim pelo seu fato gerador. O mesmo ocorre aqui. Não importa o nome dado, mas efetivamente qual é a natureza do pagamento”. MARTINS, Sérgio Pinto. Natureza do “stock option” no Direito do Trabalho, p. 6. 
conforme estipulados no respectivo plano ou em contrato de opção. Estabelecem, ainda, que caso seja demitido por justa causa antes de completado o prazo de carência de suas opções, o beneficiário perderá o direito a ele outorgado. Na hipótese de demissão sem justa causa, terá o beneficiário o direito de exercer as opções que ainda não completaram o período de carência, caso a demissão ocorra em até 180 (cento e oitenta) dias antes do término do prazo de carência da opção, na proporção de tempo que esteve vinculado à companhia.

Por fim, o inciso XVIII, do parágrafo único, do artigo 168-A do projeto de lei $\mathrm{n}^{\circ}$ 7.387/2010 dispõe sobre a justiça competente para julgar as causas relacionadas aos planos de opção de compra de ações. Segundo este dispositivo, "por se tratar de relação de empregado com empregador”, as matérias relacionadas com as stock options deverão ser analisadas e julgadas pela Justiça do Trabalho. Claramente o legislador não observou recentes julgados do próprio Tribunal Superior do Trabalho acerca da matéria. Após a análise da natureza mercantil dos planos de opção de compra de ações, a desembargadora relatora Maria Laura Franco Lima de Faria defende tratar-se de competência da justiça comum, afirmando o quanto segue:

O fato por si só do trabalhador ter ações da sua empregadora não determina a competência desta Especializada, porque esta relação é meramente mercantil e não integra o contrato de trabalho. O proveito obtido pelo empregado com a venda de ações não se confunde com o salário. Nesse caso, o empregado adquire uma personalidade mista de assalariado e capitalista. Nesse passo, tem-se que a relação entre as partes era totalmente mercantil, fugindo do âmbito da relação de trabalho ${ }^{194}$.

Entendida a contextualização normativa dos planos de opção de compra de ações, parte-se agora às suas principais características.

\subsection{PARÂMETROS IdENTIFICADORES}

Fundamental para a devida análise de um instituto jurídico é o estudo de suas características. Os parâmetros identificadores dos planos de opção de compra de ações são

\footnotetext{
194 BRASIL. Tribunal Superior do Trabalho. $8^{\text {a }}$ Turma. Recurso de Revista n. 31300-20.2010.5.17.0005. Data de Julgamento: 29 fev. 2012. Relatora: Juíza Convocada Maria Laura Franco Lima de Faria. Diário Eletrônico de Justiça do Trabalho: 02 mar. 2012
} 
bastante relevantes para que seja evitada qualquer confusão com institutos semelhantes. Nesse sentido, o presente tópico tratará do caráter pessoal das opções outorgadas no âmbito dos planos de opção, diferenciando-os, em especial, dos bônus de subscrição; no tópico seguinte serão discutidas as diferentes etapas de um plano de opção utilizando as demais características desse instituto para a referida diferenciação.

Em vista do propósito específico dos planos de opção, em especial o de garantir a um determinado grupo de pessoas a possibilidade de adquirir ou subscrever ações de emissão de uma companhia, discute-se se esses beneficiários teriam a possibilidade de transferir suas opções, negociá-las.

Defendendo a corrente de que as opções são transferíveis, destaca-se o trabalho de Mauro Brandão Lopes, para quem a regra é a de que todos e quaisquer direitos de crédito são transferíveis, exceto aqueles cuja cessão não seja possível em razão da natureza da obrigação, de dever legal ou de convenção com o devedor. Assim, em regra, as opções outorgadas no âmbito dos planos de opção seriam transferíveis, visto que a lei não estabelece nenhuma restrição à transferência e que a natureza da obrigação (um benefício outorgado a determinadas pessoas) não implica necessariamente a impossibilidade da cessão. Da mesma forma, caso não haja proibição expressa no plano autorizado pela companhia (convenção com o devedor), as opções poderiam ser livremente transferidas ${ }^{195}$.

Por outro lado, mas com ressalvas, Egberto Lacerda Teixeira e José Alexandre Tavares Guerreiro defendem que as opções não podem ser transferidas. Ao criticarem a omissão da lei, estes autores defendem o caráter pessoal da outorga das opções de compra de ações no âmbito dos planos. De acordo com este entendimento, a opção é outorgada pela companhia para determinada pessoa em razão de suas características e qualidades e por acreditar que, alinhando os seus interesses com os do beneficiário, ambos podem obter resultados favoráveis. Eventual transferência das opções para um terceiro descaracterizaria a finalidade da outorga e o seu caráter intuitu personae. Teixeira e Guerreiro advogam, assim, que, pelo menos temporariamente, as opções deveriam ser intransferíveis, não obstante a letra da lei permitir uma interpretação contrária visto que não estabelece tal restrição ${ }^{196}$. Sobre o prazo de indisponibilidade de transferência mencionado por referidos autores, é possível fazer uma analogia com o período de carência, a ser analisado adiante no presente trabalho.

\footnotetext{
195 Cf. LOPES, Mauro Brandão. S.A.: Títulos e Contratos Novos, p. 87.

196 Cf. TEIXEIRA, Egberto Lacerda; GUERREIRO, José Alexandre Tavares. Das sociedades anônimas no direito brasileiro, v. 1, p. 331.
} 
No mesmo sentido, Vera Helena de Mello Franco e Rachel Sztajn, defendendo o caráter pessoal e não transferível das opções, afirmam que as opções outorgadas no âmbito dos planos de opção de compra de ações são vinculadas àqueles que efetivamente prestam serviços à companhia, o que veda a possibilidade de serem ofertadas ao mercado. Nesse sentido, as referidas opções não devem ser caracterizadas como valor mobiliário, razão pela qual, inclusive, não constam do rol do artigo $2^{\circ}$ da Lei $n^{\circ} 6.385 / 76^{197}$.

A fim de evitar questionamentos, José Waldecy Lucena sugere, ad cautelam, a inclusão nos planos de opção aprovados pela assembleia geral de cláusula dispondo sobre a intransferibilidade das opções. Assim, nos termos do artigo 286 do Código Civil brasileiro ${ }^{198}$, a restrição seria legalmente fundamentada e oponível contra cessionário de boa-fé por expressamente resultar de convenção com o devedor, no caso, a companhia ${ }^{199}$.

Diversos são os planos das companhias brasileiras que parecem observar os ensinamentos do referido autor. O plano de opções da Drogasil, por exemplo, assim disciplina a questão da transferibilidade das opções: “10.7. As opções outorgadas nos termos deste Plano são pessoais e intransferíveis, não podendo o Beneficiário, em hipótese alguma, ceder, transferir ou de qualquer forma alienar a quaisquer terceiros as opções, nem os direitos e obrigações a elas inerentes" 200 .

Uma regulamentação clara e precisa sobre o caráter pessoal e não transferível das opções seria fundamental para o fim da discussão, visto que, se assim não o fosse, as opções não seriam originalmente outorgadas. Não é de interesse da companhia criar tal tipo de vínculo com pessoas que não prestam efetivamente serviços à companhia ou que, se prestam, não são consideradas essenciais a ponto de não serem diretamente beneficiadas com a outorga (ou com um volume maior de opções outorgadas).

O caráter pessoal das opções outorgadas no âmbito dos planos de opção de compra de ações afasta a possibilidade de transferência do risco, o que, por sua vez, as diferencia das opções negociadas em bolsas de valores ${ }^{201}$, bem como mitiga a alegação de eventual natureza

\footnotetext{
197 MELLO FRANCO, Vera Helena de; SZTAJN, Rachel. Manual de Direito Comercial, v. 2, p. 129.

198 “Art. 286 - O Credor pode ceder o seu crédito, se a isso não se opuser a natureza da obrigação, a lei, ou a convenção com o devedor; a cláusula proibitiva da cessão não poderá ser oposta ao cessionário de boa-fé, se não constar do instrumento da obrigação”. <http://www.planalto.gov.br/ccivil_03/Leis/2002/L10406compilada.htm>. Acesso em: 30 ago. 2012.

199 Cf. LUCENA, José Waldecy. Das sociedades anônimas, v. 2, p. 802.

200 Conforme ata da assembleia geral extraordinária da Drogasil realizada em 10 de novembro de 2011. Disponível em: <www.cvm.gov.br>. Acesso em: 05 mar. 2012.

201 Sobre as opções negociadas em bolsas de valores, cf. SOUZA JR., Francisco Satiro. Regime jurídico das opções negociadas em bolsas de valores, 2002.
} 
trabalhista. Francisco Satiro de Souza Júnior explica que nas operações no mercado futuro é possível assumir posições contratuais visando reduzir o risco envolvido. O objetivo do chamado hedge, portanto, é eliminar ou minimizar o risco do negócio, transferindo-o integral ou parcialmente a um terceiro ${ }^{202}$. Essa transferência, permitida nas opções negociadas em bolsas de valores, não deve ser possível, contudo, nas opções outorgadas no âmbito dos planos de opção de compra de ações, pois descaracterizaria a finalidade da companhia de reter e fidelizar determinado beneficiário, bem como poderia vir a caracterizar uma relação de natureza salarial. Se a companhia garantir o chamado floor para o beneficiário, estará de certa forma assegurando o beneficiário, afastando o risco inerente ao negócio.

Ainda em relação ao caráter pessoal das opções outorgadas no âmbito dos planos de opção, contudo, devem ser mencionados os casos em que a transferência se faz em razão do falecimento ou invalidez permanente do beneficiário. As companhias brasileiras têm majoritariamente incluído disposição em seus respectivos planos quanto ao exercício das opções por herdeiros e sucessores do antigo beneficiário. Especificam referidas cláusulas prazos de exercício em função das opções já serem ou não exercíveis. Ademais, o plano de opções da BM\&FBovespa, por exemplo, assemelha a tais eventos a hipótese de aposentadoria do beneficiário ${ }^{203}$.

\footnotetext{
202 'No 'hedge' feito através de opção, como o 'hedger' garante a si a possibilidade de concretizar a compra e venda somente se assim lhe convier, ele pode limitar suas perdas, sem abrir mão do ganho total do ativo em uma situação favorável. Suponhamos que um determinado investidor institucional, como um fundo de pensão, por exemplo, pretenda proteger as ações de sua carteira contra eventuais quedas bruscas de cotação (e consequentemente diminuição patrimonial), considerando um estado de instabilidade econômica. Em outras palavras, o investidor institucional busca reduzir seu risco de mercado. Adquirindo opções de venda de ações pelo preço de exercício que considera o mínimo admissível para a manutenção das ações, na data de exercício o investidor institucional garantirá: (i) a venda das ações pelo preço de exercício, se sua cotação ações mostrar-se abaixo dos valores admissíveis; ou (ii) a manutenção das ações (com o não exercício da opção de venda), se sua cotação se mantiver estável ou mesmo, o que é possível em épocas de grande instabilidade, apresentar tendência de alta, assegurando a si o benefício da oscilação positiva do mercado. Com a utilização dessa estratégia, o investidor institucional cria um 'piso' ('floor') abaixo do qual o valor de seus ativos (valores mobiliários) nunca estará, sem prescindir - e em caráter ilimitado - dos integrais benefícios de uma eventual alta. Se realizada em sentido contrário, ou seja, com o objetivo de se prevenir de uma eventual alta das ações em razão, por exemplo, de uma obrigação futura de entregar tais valores mobiliários, a operação é feita com opções de compra e estabelece um 'teto' para as cotações das ações, razão pela qual passa a ser chamada de 'cap'”. SOUZA JR., Francisco Satiro. Regime jurídico das opções negociadas em bolsas de valores, p 31.

203 "10.1. Se o Beneficiário falecer ou tornar-se permanentemente inválido para o exercício de sua função na Companhia enquanto administrador ou empregado, os direitos decorrentes das opções poderão ser exercidos, conforme o caso, pelo Beneficiário ou por seus herdeiros e sucessores, que os poderão exercer, tendo ou não decorrido os prazos iniciais de carência, por um período de um ano a contar da data do óbito ou invalidez permanente, após o qual estarão extintos, sem direito a indenização. 10.2. A opção poderá ser exercida no todo ou em parte, com pagamento à vista, partilhando-se entre os herdeiros ou sucessores o direito às ações, na forma de disposição testamentária ou conforme estabelecido no inventário respectivo. 10.3. As ações que vierem a ser subscritas pelo Beneficiário inválido, por seus herdeiros ou sucessores estarão livres e desembaraçadas para venda a qualquer momento. 10.4. As disposições dos itens 10.1 e 10.3 desta cláusula aplicam-se também em caso de aposentadoria do Beneficiário, desde que o Beneficiário se comprometa a não prestar serviços, com ou sem vínculo empregatício, a empresas e instituições que, mesmo de forma indireta, atuem em mercados
} 
Dessa forma, antes de analisarem-se as demais características dos planos de opção, que serão expostas na medida em que forem descritas as fases dos planos, faz-se necessária uma clara diferenciação entre esse instituto e os bônus de subscrição.

\subsubsection{Diferenciação entre os Planos de Opção e os Bônus de Subscrição}

Os planos de opção de compra de ações são comumente associados aos bônus de subscrição por sua “característica” de emissão de novas ações, o que nem sempre acontece, uma vez que, conforme já mencionado, as opções de ações outorgadas no âmbito de planos aprovados em assembleias gerais também englobam, caso não haja expressa ressalva em contrário, a possibilidade de aquisição de ações já existentes e mantidas em tesouraria.

Deve-se destacar desde logo que se trata de institutos absolutamente distintos, com finalidades diversas. O bônus de subscrição é um título negociável emitido nos termos do artigo 75 da Lei das Sociedades por Ações ${ }^{204}$. Garante aos seus detentores o direito de subscrever ações do capital social de uma determinada sociedade em futuros aumentos de capital, nos termos constantes do respectivo certificado. Podem, ainda, ser alienados pela companhia ou por ela atribuídos como vantagem adicional aos subscritores de emissões de suas ações ou debêntures ${ }^{205}$. Nesse sentido, enquanto os bônus de subscrição visam financiar

coincidentes ao da Companhia, durante, no mínimo, 120 dias”. Conforme plano aprovado pela BM\&FBovespa em assembleia geral realizada em 8 de maio de 2008. Conforme ata da Assembleia Geral Extraordinária da BM\&FBovespa S.A. - Bolsa de Valores, Mercadorias e Futuros, realizada em 8 de meio de 2008. Disponível em: <www.cvm.gov.br>. Acesso em: 9 set. 2012.

204 “Art. 75. A companhia poderá emitir, dentro do limite de aumento do capital autorizado no estatuto (Art. 168), títulos negociáveis denominados 'bônus de subscrição'. Parágrafo único. Os bônus de subscrição conferirão aos seus titulares, nas condições constantes do certificado, direito de subscrever ações do capital social, que será exercido mediante apresentação do título à companhia e pagamento do preço de emissão das ações”. Disponível em: <http://www.planalto.gov.br/ccivil_03/Leis/L6404compilada.htm>. Acesso em: 28 ago. 2012.

${ }^{205}$ Conforme artigo 77 da Lei das Sociedades por Ações: “Art. 77. Os bônus de subscrição serão alienados pela companhia ou por ela atribuídos, como vantagem adicional, aos subscritores de emissões de suas ações ou debêntures. Parágrafo único. Os acionistas da companhia gozarão, nos termos dos Arts. 171 e 172, de preferência para subscrever a emissão de bônus”. <http://www.planalto.gov.br/ccivil_03/Leis/L6404compilada.htm>. Acesso em: 28 ago. 2012. 
ou aumentar a disponibilidade de recursos para as companhias, as opções procuram favorecer o fator trabalho no funcionamento das sociedades ${ }^{206}$.

Corroboram a ideia de que as opções de compra diferenciam-se dos bônus de subscrição pelo caráter remuneratório Vera Helena de Mello Franco e Rachel Sztajn, as quais destacam, ainda, que as opções não podem ser utilizadas como fonte de financiamento ${ }^{207}$.

Em relação à diferenciação entre as opções e os bônus de subscrição, muito esclarecedores são o relatório e o fundamento do Processo CVM n ${ }^{\circ}$ SP 2002/0474 (RC n ${ }^{\circ}$ 3948/2002) ${ }^{208}$. Em referido caso, discute-se o critério de determinação do preço de exercício de determinados bônus de subscrição que possuem cláusula antidiluição. Tal cláusula estabelecia que o preço de eventuais aumentos de capital, por subscrição pública ou privada, quando inferior ao valor ajustado de emissão dos bônus de subscrição, passaria a ser o novo patamar, devendo o preço dos bônus ser corrigido e ajustado conforme tal preço inferior de aumento de capital. Discutia-se, assim, se o preço de subscrição da ação decorrente do plano de opção de compra deveria influenciar o preço de emissão das ações em razão do exercício do direito do bônus. Para sustentar suas diferentes posições, as partes envolvidas se valeram de excelentes pareceres que, por sua vez, fundamentaram seus argumentos na diferenciação desses institutos.

A Procuradoria Jurídica da CVM - PJU, por exemplo, baseou sua diferenciação na negociabilidade dos bônus de subscrição, característica ausente nas opções. Segundo a argumentação da referida procuradoria, a opção é um título nominativo e não negociável, o contrário, portanto, dos bônus de subscrição. Estes são dotados de negociabilidade e conferem ao seu titular, mediante a apresentação do título à companhia e pagamento do preço de emissão, o direito de subscrever ações do capital social nos termos constantes do respectivo certificado.

José Luiz Bulhões Pedreira, por sua vez, diferenciou ambos os institutos pela vantagem econômica pretendida pela legislação aplicável. No caso em questão, seria absurdo estender aos titulares dos bônus de subscrição uma vantagem econômica que a Lei das Sociedades por Ações conferiu somente a administradores ou empregados, ou a pessoas

\footnotetext{
${ }^{206}$ Sobre o tema, Alfredo Lamy Filho afirma que "são institutos juridicamente distintos, que atendem a objetivos diversos, utilizados com intenções diferentes, e os preços de emissão dos bônus e seus eventuais ajustes (sobre os quais já se manifestaram os acionistas no exercício de seu direito de preferência), jamais poderiam vincular-se ao da outorga de uma opção a empregados (sobre os quais os acionistas não tem preferência)”. LAMY FILHO, Alfredo. Temas de S.A. Rio de Janeiro: Renovar, 2007. p. 380.

${ }^{207}$ Cf. MELLO FRANCO, Vera Helena de; SZTAJN, Rachel. Manual de Direito Comercial, v. 2, p. 129.

${ }^{208}$ Disponível em: <http://www.cvm.gov.br/>, acesso em 11 de maio de 2011.
} 
naturais que prestem serviços à companhia ou a sociedade sob seu controle, além do fato de que caracterizaria uma diluição injustificada da participação acionária dos acionistas não titulares de bônus.

Mauro Rodrigues Penteado justifica a não confusão de ambos os institutos em razão do método de precificação de cada um deles e, consequentemente, no direito de preferência e na diluição injustificada da participação dos demais acionistas. Segundo o autor, no caso das opções a sociedade não necessariamente deve seguir os critérios determinados pelo artigo 170 da Lei das Sociedades por Ações. Assim, os preços de aquisição ou subscrição normalmente são inferiores àqueles calculados segundo o artigo 170, justamente para atrair o interesse dos beneficiários e, de fato, caracterizar a outorga das opções como um incentivo. Esse incentivo é a razão da "diluição" (diminuição da participação acionária) dos demais acionistas e o motivo do afastamento do direito de preferência dos mesmos, o que não ocorre com os bônus de subscrição. Na mesma linha, José Alexandre Tavares Guerreiro sintetiza a discussão no direito de preferência: “a par de traços comuns que, de fato apresentam, a opção e o bônus distinguem-se por um importante elemento diferencial, ausente na primeira e presente no último: o direito de preferência”.

Francisco Costa e Silva, além do direito de preferência e da diluição injustificada da participação acionária, indica também o fato de os bônus de subscrição serem transferíveis, ao passo que nem sempre tal característica é encontrada nas opções, conforme já analisado na presente dissertação ${ }^{209}$. Já a diferente finalidade das opções de compra e a dos bônus de subscrição é o argumento de Alfredo Lamy Filho; enquanto os bônus de subscrição visam ao financiamento da companhia pela maior disponibilidade de recursos, as opções de compra procuram favorecer o fator trabalho.

Norma Jonssen Parente, seguindo os argumentos ${ }^{210}$ levantados no voto dissidente da analista Elessandra Pombo Corrêa da Gerência de Acompanhamento - GEA2, conclui que

\footnotetext{
${ }^{209}$ Francisco Costa e Silva afirma ainda que “a) é da natureza do bônus de subscrição sua livre transferibilidade, enquanto que a opção não pode ser transferida, salvo por sucessão hereditária; (...) c) a opção de compra de ações constitui um direito especialíssimo à disposição da companhia, o qual prevê, para o seu exercício, um aumento de capital sui generis, sem a necessidade de preservar o direito essencial do acionista de preferência na subscrição desse aumento; (...) h) a inclusão, nas condições de ajuste do preço de subscrição contido nos bônus de subscrição, dos aumentos de capital decorrentes do exercício do plano de opção de compra de ações, representaria verdadeira afronta à lei societária, principalmente no que pertine à proteção dos acionistas da companhia contra a diluição injustificada da sua participação no capital social; (...) l) a opção de compra de ações, ao contrário do bônus de subscrição, não se submete ao regime dos aumentos ordinários de capital, principalmente as regras do art. $170, \S 1^{\circ}$, uma vez que representa exclusivamente forma de remuneração indireta de administradores, empregados e prestadores de serviços".

210 "a) a decisão de adquirir ou de negociar os bônus foi tomada com base nas condições estabelecidas, ou seja, que quaisquer aumentos de capital, públicos ou privados, a preço de subscrição inferior ao preço de subscrição
} 
não deve ser incluído na determinação do preço de exercício dos bônus de subscrição o preço de emissão de novas ações oriundas do plano de opção de compra de ações e resume a distinção entre opções de compra e bônus de subscrição utilizando três principais características: a negociabilidade, os destinatários e o direito de preferência ${ }^{211}$.

Esclarecidas as distinções entre os bônus de subscrição e os planos de opção de compra de ações, passa-se à análise sobre como estes costumam ser estruturados nas sociedades por ações abertas brasileiras.

5.4 . “FASES” dos Planos de OPÇÃo

Com base na análise dos planos de opção de compra de ações das companhias abertas brasileiras listadas no Novo Mercado da BM\&FBovespa, pretende-se no presente tópico expor os principais e mais frequentes “momentos” identificados nos planos. Não se

inicial do bônus seriam considerados no ajuste do preço de subscrição; b) o entendimento manifestado pela AmBev em 04.11.2002 veio modificar as condições previamente estabelecidas para fixação do preço de subscrição dos bônus de subscrição, tanto assim que a informação constante nas notas explicativas às demonstrações financeiras de 31.12.2002 teve seu sentido modificado em relação aos anos anteriores; c) os bônus foram negociados no mercado ao longo do tempo refletindo no preço o valor correspondente ao benefício que deles se esperava, do contrário, teriam sua circulação interrompida, diante do esvaziamento econômico que lhes teria sido imposto frente à incompatibilidade entre o valor de subscrição previsto no bônus e aquele praticado pelo mercado; d) casos os aumentos de capital relacionados ao plano não devessem ser considerados na determinação do preço de subscrição dos mencionados bônus, tal fato deveria ter sido explicitado quando da fixação e divulgação dos critérios para sua determinação"

211 "38. A despeito de todas as opiniões abalizadas manifestadas a respeito do assunto, parece-me inquestionável que estamos diante de dois institutos que têm funções completamente distintas. Enquanto o bônus de subscrição é um valor mobiliário negociável e confere ao seu titular o direito de subscrever ações se verificadas determinadas condições preestabelecidas, a opção de compra não é valor mobiliário e nem transferível, embora dê ao destinatário também o direito de adquirir ações a um preço preestabelecido. 39. Mas as diferenças não param por aí. No caso em análise, o bônus foi vendido aos acionistas que tiveram o direito de preferência respeitado, ao passo que a opção é conferida a executivos e empregados de alto nível da AmBev, na definição do próprio plano, como vantagem adicional e estímulo à expansão, ao êxito e à consecução dos objetivos sociais da companhia e dos interesses de seus acionistas. 40. Não há dúvida de que os bônus e as opções não só possuem natureza diversa como as finalidades são distintas, já que os bônus se destinam ao público investidor e as opções exclusivamente a funcionários e prestadores de serviços. Ao tratar do assunto, José Edwaldo Tavares Borba ${ }^{(1)}$ faz a seguinte distinção entre o bônus e a opção, que me parece bastante esclarecedora: 'É essa a grande distinção entre o bônus de subscrição e a opção de compra de ações. O primeiro destina-se ao universo externo da sociedade, objetivando o mercado; o segundo circunscreve-se ao âmbito das relações internas.' 41. A excepcionalidade da opção é tão relevante que, repita-se, a lei societária enumera entre os direitos essenciais do acionista o direito de preferência (art. 109), não permite a sua exclusão nem pelo estatuto nem pela assembléia geral, salvo em hipóteses expecialíssimas (sic). Todavia, expressamente, admite a outorga de opção de compra de ações sem sequer dar direito de preferência aos antigos acionistas, tal a excepcionalidade da opção. O mesmo privilégio não foi outorgado aos bônus de subscrição.” (1) BORBA, José Edwaldo Tavares. Direito Societário, p. 290. Disponível em: <www.cvm.gov.br>. Acesso em: 07 set. 2012. 
pretende propor um modelo ideal de plano de opção, que deve estar em consonância com interesses intrínsecos e peculiaridades de cada sociedade; a proposta é analisar as disposições usualmente adotadas. No entanto, a compreensão dos diferentes estágios da vida de um plano de opção é fundamental, em especial para verificar se a finalidade planejada em sua criação foi alcançada após vários anos.

É notório que as empresas listadas nos segmentos especiais da BM\&FBovespa tiveram um impacto positivo no preço, volume de negociações e liquidez de suas ações. Em 6 de julho de 2012, conforme informações divulgadas no website da BM\&FBovespa, eram: (i) 33 companhias listadas no Nível 1; (ii) 20 companhias listadas no Nível 2; e (iii) 129 companhias listadas no Novo Mercado. Assim, entre os três segmentos, o Novo Mercado é aquele que possui o maior número de práticas recomendadas e é o mais adotado pelas companhias abertas brasileiras. Nesse sentido, justifica-se a escolha das empresas que aderiram ao Novo Mercado para a análise dos planos de opção, visto que é a tendência atual das companhias brasileiras em termos de melhoria de governança corporativa.

Assim, as fases de um plano de opção podem ser agrupadas em quatro grandes etapas: (i) a aprovação do plano; (ii) o período de aquisição do direito de exercício da opção; (iii) o período de exercício da opção; e (iv) a alienação das ações adquiridas em razão do plano de opção.

Destaca-se que essas fases são apenas sugestivas para os fins didáticos do presente trabalho. Como mencionado, exceto pelo disposto no artigo 168, § $3^{\circ}$, da Lei das Sociedades por Ações, acima analisado, a atual legislação brasileira não prescreve qualquer formato a ser seguido, assim como não estabelece requisitos mínimos que devam constar dos planos para que estes sejam aprovados em assembleia. Ademais, em alguns planos essas fases podem se confundir ou se desenvolver simultaneamente, não existindo um limite bem definido entre elas $^{212}$.

${ }^{212}$ Diferentemente, por exemplo, sem mencionar a aprovação do plano de opções pela assembleia geral, Marcos André Vinhas Catão sistematiza e resume os planos de opção da seguinte forma: "Em linhas gerais, os stock options plans são estruturados sob contrato escrito, firmado entre a entidade concedente (empresa emissora da ação) e o prestador do serviço (funcionário, administrador ou terceirizado), pelo qual: (i) em um primeiro momento, (data da concessão) é concedido ao prestador o direito de aquisição de ações da empresa, por um valor referenciado naquela data (valor da opção), a ser exercido em momento seguinte, e após certo transcurso de tempo contratualmente estabelecido; (ii) passado este período (vesting period), extingue-se a condição suspensiva, podendo o então prestador realizar a aquisição da ação como um ativo próprio para posterior realização. Ou seja, ultrapassado o prazo de carência e uma vez exercida a opção pelo valor previamente estipulado (aquisição da ação), integra-se ao patrimônio um direito economicamente apreciável, ainda que não seja transformado imediatamente em pecúnia com a venda da ação; (iii) em momento subsequente, ou ato continuo à realização da opção, o prestador, ora titular de um direito de crédito (parcela do capital), poderá 
A primeira fase inicia-se com a aprovação em assembleia geral do plano de opção de compra de ações. Por iniciativa dos próprios acionistas ou a partir da proposta da administração, o plano é analisado e discutido pelos acionistas e, se aprovado, passa a gerar efeitos perante a sociedade. Nesse momento, são estabelecidas as diretrizes gerais dos planos de opção, as quais serão a seguir detalhadas.

Essa primeira fase - novamente, para os fins do presente trabalho - encerra-se $\mathrm{e}^{213}$ com a outorga das opções de compra ou subscrição a determinadas pessoas, nos termos e condições estabelecidas no plano pela assembleia geral ou pelo conselho de administração. Por meio da celebração de contratos específicos ou por programas de outorga, são estabelecidas as condições da outorga das opções, o número de ações que o beneficiário terá direito a adquirir ou subscrever com o exercício das opções, entre outros aspectos.

Uma vez outorgada a opção a um determinado beneficiário, pode existir ou não, conforme determinado pelo plano ou pelo administrador do plano, um período de indisponibilidade das opções, podendo ainda ser condicionado tal período à ocorrência de determinados eventos. Comumente chamado de "período de carência”, essa fase do plano de opção de compra também é conhecida pela expressão vesting period ou até mesmo "período de maturação”. Superado esse período - caso existente -, as opções podem ser exercidas pelo beneficiário.

A etapa seguinte é a do efetivo período do exercício pelo beneficiário de suas opções, isto é, quando as ações adquiridas ou subscritas passam para o seu patrimônio. Na forma e condições determinadas pelo plano, o exercício pode se dar conforme a melhor conveniência do beneficiário. É-lhe facultado na maioria dos casos decidir o momento ideal para o exercício de seu direito (normalmente relacionado ao valor de mercado das opções, em se tratando de companhias abertas com ações negociadas em bolsas de valores). Em alguns casos, as fases do plano de opções podem ser interrompidas nesse momento. Se assim dispuser o plano, caso o beneficiário não exerça em determinado período de tempo as suas opções, decai seu direito de adquirir ou subscrever ações.

alienar esse bem por valor inferior, igual ou superior ao despendido para sua respectiva aquisição, de acordo com o parâmetro contratual estabelecido. Por certo que a intenção do beneficiário de um plano de stock options é auferir, ao final dessa operação, a melhor relação entre o preço de aquisição e o de venda, com a verificação de um ganho”. CATÃO, Marcos André Vinhas. Tributação de Stock Options.

213 Destaca-se que a aprovação do plano e a efetiva outorga das opções podem ocorrer simultaneamente; por isso, no presente trabalho, sugerem-se dois momentos distintos a fim de justamente deixar claro que podem ou não ocorrer simultaneamente. 
Devidamente exercidas pelo beneficiário, as opções deixam de existir, passando o beneficiário a ser titular de ações de emissão da companhia decorrentes do plano. Nessa última fase dos planos de opção, o beneficiário pode optar por manter em sua titularidade as ações ou aliená-las, restando-lhe a diferença entre (i) o valor de exercício acrescido de eventual prêmio referente à aquisição da opção e (ii) o valor da alienação das ações. Nos termos e condições aprovados pelos acionistas em assembleia geral, os beneficiários podem ainda estar sujeitos a restrições na transferência das ações adquiridas em virtude do plano. Caso existente, o chamado lock up period normalmente impede o beneficiário de alienar as suas ações por determinado período ou permite a venda gradual das mesmas, conforme será analisado adiante.

É importante destacar nessa última fase a liquidez das opções adquiridas. De modo semelhante às transações de valores mobiliários no mercado de valores, a liquidez das opções reflete a facilidade de sua conversão em moeda. A liquidez das opções tende a ser maior ou menor na proporção do tamanho dos vesting e lock up periods. Ao tratar o tema da liquidez no mercado de valores mobiliários, Rachel Sztajn explica que

a criação de riqueza no mercado de valores mobiliários, entretanto, depende da liquidez, da facilidade e da rapidez de circulação, transferência dos ativos, sem o que não se atrairão interessados, investidores e especuladores, que o movimentem, que ajustem a troca de investidores atuais e potenciais ${ }^{214}$.

Assim, sob o enfoque o beneficiário, um determinado plano que proporcionar boa liquidez às suas opções será mais atrativo aos seus beneficiários e, por consequência, terá maiores chances de atingir seus objetivos. Por outro lado, quanto maiores os óbices à alienação das ações pelo beneficiário, menores as chances de o plano ser bem-sucedido.

Vejam-se em detalhes os principais aspectos de cada uma das fases acima mencionadas.

\subsubsection{Aprovação do Plano}

Conforme dispõe a Lei das Sociedades por Ações, o plano de opção de compra de ações de uma companhia deve ser aprovado por seus acionistas em assembleia geral. Nesse

\footnotetext{
${ }^{214}$ SZTAJN, Rachel. Conceito de liquidez na disciplina do mercado de valores mobiliários. Revista de Direito Mercantil, industrial, Econômico e Financeiro, São Paulo, v. 41, n. 126, p. 7-30, abr./jun. 2002. p. 10.
} 
momento os acionistas determinam a forma de administração do plano, quais são os critérios para a escolha das pessoas elegíveis, bem como a quantidade máxima de opções que poderão ser outorgadas sob os termos e condições do mesmo.

Assume-se, portanto, que, para a aprovação do plano em assembleia geral, os demais requisitos constantes do artigo 168, $\S 3^{\circ}$, da Lei das Sociedades por Ações já tenham sido atendidos; ou seja, subtende-se que antes do início da vida de um plano de opção de compra de ações o estatuto social da companhia (i) já contenha previsão expressa da possibilidade de plano de opções; e (ii) determine os limites do capital autorizado aos quais se submete o plano.

\subsubsection{Forma de Administração}

Em regra, não são os próprios acionistas da companhia que gerenciam o dia a dia do plano de opção por eles aprovado ${ }^{215}$. Os planos costumam ser administrados pelo conselho de administração da companhia ou por um comitê especialmente criado para tal propósito, conforme as diretrizes estabelecidas pelos acionistas.

Os termos e condições das outorgas costumam ser determinados em contratos específicos celebrados individualmente com cada um dos beneficiários ou em programas de outorgas aprovados pelo conselho ou pelo comitê, conforme o caso.

Esses programas, que podem ser criados periodicamente ou não, definirão, por exemplo, os seus potenciais beneficiários; o número total de ações da sociedade objeto de outorga e, eventualmente, sua divisão em lotes; o preço de exercício das opções; eventuais prazos de carência durante o qual a opção não poderá ser exercida, os períodos para o exercício das opções e as datas limite para o exercício total ou parcial das opções, nas quais os

\footnotetext{
${ }^{215}$ Não obstante, é interessante citar o casos das empresas do Grupo X. As sociedades controladas pelo empresário brasileiro Eike Batista possuem, além dos planos convencionais, uma segunda espécie de remuneração variada baseada em ações: um plano em que o outorgante não é a companhia, mas sim o acionista controlador (propriamente falando, portanto, não se trata de planos de opção de compra de ações, conforme requisitos da Lei das Sociedades por Ações). "Por se tratar de opção de compra outorgada diretamente pelo acionista controlador, tais opções, se exercidas, não requerem a emissão de novas ações e, portanto, não resultarão na diluição dos demais acionistas da companhia”. Conforme Formulário de Referência da MMX Mineração e Metálicos S.A., data base 5 de maio de 2007, item 13.4.a. Disponível em: <www.cvm.gov.br>. Acesso em: 09 set. 2012.
} 
direitos decorrentes da opção expirarão; eventuais restrições à alienação das ações subscritas ou adquiridas em razão do exercício da opção (o chamado lock-up period); eventuais metas relacionadas ao desempenho dos empregados, dos administradores ou da sociedade, de forma a estabelecer critérios objetivos para a eleição de beneficiários e a determinação do número de opções, entre outros aspectos.

A fim de definir com precisão a competência de cada um dos órgãos responsáveis pela administração dos planos de opção, algumas companhias estabelecem expressamente um rol das competências de cada órgão da sociedade em relação à administração do plano de opções $^{216}$, bem como eventuais proibições à assembleia e ao conselho ${ }^{217}$. Aprovado o plano de opções e determinado o órgão competente para administrá-lo, passa-se à análise sobre quem são as pessoas que podem ser beneficiadas pelo mesmo.

\subsubsection{2. $\quad$ Elegibilidade e Critérios}

Dispõe o $\S 3^{\circ}$ do artigo 168 da Lei das Sociedades por Ações que o plano aprovado pela assembleia geral pode outorgar opção de compra de ações “a seus administradores ou

\footnotetext{
${ }^{216}$ A Ecorodovias, por exemplo, estabelece: “3.1.1. A Assembleia Geral da Companhia terá competência exclusiva dentro do escopo deste Plano de Opção para: (i) deliberar e aprovar as normas relativas à outorga de Opções e alterações a este Plano de Opção; (ii) deliberar, a qualquer momento, a outorga de Opções nos termos deste Plano de Opção a membros elegíveis como Beneficiários que ainda não tenham sido contemplados com este benefício; (iii) deliberar e aprovar as normas específicas quanto ao preço do exercício das Opções pelo Beneficiário, pagamento, prazos e demais condições para o exercício das Opções pelos Beneficiários; (iv) deliberar e aprovar os Beneficiários a quem serão endereçadas Ofertas de Opção de Compra de Ações nos termos deste Plano de Opção; (v) deliberar e aprovar o limite e quantidade máxima de Ações sujeitas a este Plano de Opção; e (vi) deliberar e aprovar as datas de outorga das Opções, a quantidade de Opções a serem outorgadas a cada Beneficiário, bem como a modificação de tais condições quando necessário para adequar as Opções aos termos de lei, norma ou regulamento superveniente”. Conforme ata da Assembleia Geral Extraordinária da Ecorodovias Infraestrutura e Logística S.A., realizada em 31 de agosto de 2010. Disponível em: <www.cvm.gov.br>. Acesso em: 09 set. 2012.

217 “3.2. A Assembleia Geral da Companhia e/ou o Conselho de Administração não poderão, em qualquer hipótese, com base neste Plano de Opção, conferir aos Beneficiários quaisquer direitos que: (i) assegurem sua reeleição ou permanência na administração da Companhia e/ou na de suas Controladas, até o término de seu mandato, tampouco impeçam sua destituição a qualquer tempo no cargo que ocupe na Companhia e/ou na Controlada; e/ou (ii) assegurem sua permanência como empregado da Companhia e/ou qualquer empresa do grupo econômico, tampouco impeçam o término de sua relação de trabalho a qualquer tempo pela Companhia e/ou qualquer empresa do grupo econômico”. Conforme ata da Assembleia Geral Extraordinária da Ecorodovias Infraestrutura e Logística S.A., realizada em 31 de agosto de 2010. Disponível em: <www.cvm.gov.br>. Acesso em: 09 set. 2012.
} 
empregados, ou a pessoas naturais que prestem serviços à companhia ou a sociedade sob seu controle”.

Pela leitura e interpretação gramatical do dispositivo acima citado, poder-se-ia chegar à conclusão de que os administradores e empregados das sociedades controladas pela companhia que aprovou o plano de opção não teriam sido abrangidos pela vontade do legislador. Nesse sentido, Maria da Aparecida Cunha Lana, no Parecer SJU nº 37/1984 da CVM, afirma:

De tal maneira, o que a lei expressamente disse é que a companhia pode outorgar opção de compra a seus administradores e empregados, (não aos da sociedade coligada), e às pessoas naturais que prestem serviço a ela e a sociedade sob seu controle. Não se há de interpretar que “administradores e empregados” já estariam contidos na expressão “pessoas naturais que prestam serviço”, pois a lei utilizou termos técnicos que se não confundem, nem o último é gênero que abrigue os demais, como espécies ${ }^{218}$.

Esse entendimento, contudo, não deve $\operatorname{prosperar}^{219}$. Atualmente a doutrina brasileira é pacífica em relação à interpretação de que podem também ser outorgadas opções a administradores de sociedades controladas, bem como a pessoas naturais que prestem serviços à companhia e suas controladas ${ }^{220}$.

218 Disponível em: <www.cvm.gov.br>. Acesso em: 08 mar. 2012.

219 A própria CVM, por meio da sua Superintendência Jurídica, retificou referido entendimento.

${ }^{220}$ Nesse sentido, afirmam Egberto Lacerda Teixeira e José Alexandre Tavares Guerreiro: "Seguindo a orientação geral da jurisprudência norte-americana, parece-nos que as opções em questão tem como justificativa a conveniência, para a sociedade, de remunerar, com esse benefício sui generis, o trabalho de seus administradores, empregados ou de pessoas naturais que lhe prestem serviços ou ainda pessoas naturais que prestem serviços a sociedade sob seu controle. De fato, de acordo com a experiência do instituto nos Estados Unidos, deve haver uma correlação entre o valor dos benefícios auferidos pela companhia, decorrentes dos serviços prestados pelos outorgados, e o valor das opções outorgadas ${ }^{(8)}$. A nosso ver, pecou a lei brasileira ao não exigir expressamente que a outorga de opções tenha conteúdo contra prestacional. Parece-nos, entretanto, que a melhor interpretação dos dispositivos pertinentes deve levar a tal conclusão, afastando-se a possibilidade de outorgas fraudulentas, de mero favor, destinadas a aquinhoar pessoas que não contribuam efetivamente para as atividades da empresa, em detrimento dos acionistas que, como ficou dito, ficam privados do direito de preferência relativo à subscrição de ações do capital autorizado”. (8) Veja-se, a respeito, farta jurisprudência citada em 'Delaware Corporation Law Annotated - 1976', 16. ed., CT Corporation System, p. 104 e seguintes. Como exemplo, vejam-se os seguintes pronunciamentos judiciais: (a) 'Stock options plan for officers and employees is defective where conditions are lacking reasonably insuring that corporation will receive benefits contemplated' e (b) 'While a corporation may Grant an option to its officers to purchase its stocks, the corporation must receive some consideration in return, and IF in the form of services, their value must bear some reasonable relation to the value of the right given'”. TEIXEIRA, Egberto Lacerda; GUERREIRO, José Alexandre Tavares. Das sociedades anônimas no direito brasileiro, v. 1, p. 328 e 329. 


\title{
5.4.1.3. Diminuição de Participação Acionária
}

Ressalta-se que é pré-requisito para a existência de um plano de opção de compra de ações a sua aprovação em assembleia geral de acionistas. Um dos motivos para tanto é justamente a diminuição da participação dos acionistas na sociedade, determinada pela outorga de opções que serão convertidas em ações de emissão da companhia.

Dispõe o artigo 171, § $3^{\circ}$, da referida lei que

os acionistas terão direito de preferência para subscrição das emissões de debêntures conversíveis em ações, bônus de subscrição e partes beneficiárias conversíveis em ações emitidas para alienação onerosa; mas na conversão desses títulos em ações, ou na outorga e no exercício de opção de compra de ações, não haverá direito de preferência. (Grifos ausentes no original)

Nesse sentido, observa-se que a diminuição da participação acionária em virtude do exercício das opções pelos beneficiários no âmbito do plano de opções está em conformidade com a legislação brasileira em vigor, a qual entende justificável a diluição da participação dos antigos acionistas. Norma Johssen Parente afirma sobre o assunto:

\begin{abstract}
Justifica-se, pois a sua outorga representa um prêmio àqueles que com seu trabalho contribuíram para o desenvolvimento e crescimento da empresa. Diante disso, é normal que o preço de emissão para os trabalhadores seja inferior ao preço justo, previsto no parágrafo 10 do art. 170 da lei societária. Na verdade, a opção representa uma remuneração adicional para aqueles empregados que mais se destacaram. $\mathrm{O}$ valor da subscrição tem preço subsidiado ${ }^{221}$.
\end{abstract}

Em uma companhia com um controlador definido, a aprovação de um plano de opções pode se dar de forma relativamente fácil, não obstante haver voto contrário de minoritários. Estes não terão direito de preferência e nem direito de recesso. É importante destacar, contudo, que a decisão do controlador deve ser justificada. Nos termos do artigo 115 da Lei das Sociedades por Ações, o acionista deve exercer o direito a voto no interesse da companhia; não deve causar ou agir de forma a resultar dano ou prejuízo para a companhia ou para outros acionistas, tampouco deve agir de forma a obter, para si ou para outrem, vantagem a que não faz jus.

\footnotetext{
${ }^{221}$ Processo CVM no SP 2002/0474 (RC No 3948/2002). Disponível em: <http://www.cvm.gov.br/>. Acesso em: 11 maio 2011.
} 
A diminuição injustificada na participação de acionistas minoritários poderia, assim, caracterizar o voto abusivo do controlador. Ademais, ressalta-se que o acionista controlador responde pelos danos causados por atos praticados com abuso de poder. Nos termos do artigo 117, $\S 1^{\circ}$, “e”, da Lei das Sociedades por Ações, induzir administrador a praticar ato ilegal ou promover, contra o interesse da companhia, sua ratificação pela assembleia geral, é modalidade de exercício abusivo de poder. Nesse sentido, segundo Egberto Lacerda Teixeira e José Alexandre Tavares Guerreiro,

decorre que a aprovação, pela Assembleia Geral, de um stock option plan, nos termos do $\S 3 .^{\circ}$ do art. 168 há de levar em conta, fundamentalmente, que a outorga da opção deve ter por finalidade remunerar serviços efetivos a ela prestados pelos beneficiários ou, pelo menos, incentivar a permanência na empresa de administradores ou empregados capazes, cujo concurso se mostre benéfico ao bom desenvolvimento das atividades sociais ${ }^{222}$.

\subsection{2. $\quad$ Período de Carência (Vesting Period)}

De forma a atender um dos principais objetivos quando da aprovação de um plano de opção - qual seja, o de retenção dos beneficiários -, é comum (e justo) estabelecer certos períodos de indisponibilidade das opções.

Esses períodos nada mais são do que prazos dentro dos quais os beneficiários dos planos de opção não podem se valer de seus direitos, isto é, não podem exercer as opções a eles outorgadas. Trata-se de uma condição suspensiva. Esses prazos são o que a doutrina norte-americana costuma chamar de vesting period ou, no Brasil, de "período de carência” ou “período de maturação”.

Tais períodos de carência podem seguir procedimentos de liberação periódica de determinados percentuais de acordo com o tempo de permanência do beneficiário na companhia ("período escalonado”) ou observar outros critérios estabelecidos pelo próprio plano ou pelos administradores do plano, normalmente o conselho de administração ou um comitê especialmente formado para tanto.

\footnotetext{
222 TEIXEIRA, Egberto Lacerda; GUERREIRO, José Alexandre Tavares. Das sociedades anônimas no direito
} brasileiro, v. 1, p. 330. 
Segundo a Instrução CVM nº 323, artigo $1^{\circ}$, XII, é uma modalidade de exercício abusivo do poder de controle da companhia aberta a instituição de plano de opção de compra de ações deixando a exclusivo critério dos participantes do plano o momento do exercício da opção e sua venda, sem o efetivo comprometimento com a obtenção de resultados, em detrimento da companhia e dos acionistas minoritários. Assim, para Paulo Cezar Aragão e Daniela Soares, a existência de prazos de carência ${ }^{223}$ e de outros mecanismos semelhantes previstos nos planos de opção é justificada pela vinculação do benefício ao efetivo comprometimento com a obtenção de resultados, em consonância, portanto, à referida instrução. Afirmam os referidos autores que para atender ao objetivo da retenção dos beneficiários e do comprometimento com os resultados futuros, é justificável a imposição de restrições ao exercício das opções. Segundo eles,

Há que se estabelecer perspectivas de ganho e, ao mesmo tempo, eliminá-las ou reduzi-las significativamente em caso de desligamento da companhia, em especial o desligamento voluntário ou por justa causa, como dito antes, ou ainda o desligamento em curto prazo, o que usualmente se obtém por estruturas contratuais relativamente complexas ${ }^{224}$.

Além do prazo de carência baseado no transcurso de tempo, algumas companhias estabelecem outras condições para que os beneficiários possam exercer suas opções. A Ecorodovias, por exemplo, condiciona o exercício das opções à existência de reservas de lucros acumulados em valores suficientes para realizar a recompra de ações de sua própria emissão; e/ou à existência de ações em tesouraria em quantidades suficientes para cumprimento de todas as opções outorgadas, caso a recompra de ações de sua própria emissão já tenha sido concluída ${ }^{225}$.

Adicionalmente aos resultados da própria companhia, conforme exemplo acima, algumas sociedades condicionam o vesting das opções ao próprio desempenho do beneficiário $^{226}$. Este somente poderá exercer as opções que lhe forem outorgadas caso cumpra

\footnotetext{
223 Estes são os mais comuns. Egberto Lacerda Teixeira e José Alexandre Tavares Guerreiro, por exemplo, em defesa da existência do período de carência ao qual se devem sujeitar os beneficiários para que possam ser contemplados com a opção, sustentam que “(...) na casuística do direito americano encontramos tal requisito com frequência: o benefício só pode ser conferido, e.g., a empregados que contém mais de dois anos de serviço efetivo na empresa”. TEIXEIRA, Egberto Lacerda; GUERREIRO, José Alexandre Tavares. Das sociedades anônimas no direito brasileiro, v. 1, p. 329 e 330.

224 ARAGÃO, Paulo Cezar; SOARES, Daniela. Opções de Compra de Ações, p. 163 e 164.

225 Conforme ata da Assembleia Geral Extraordinária da Ecorodovias Infraestrutura e Logística S.A., realizada em 31 de agosto de 2010. Disponível em: <www.cvm.gov.br>. Acesso em: 9 set. 2012.

${ }^{226}$ Nesse sentido, “[t]he Forbes definition of total pay excludes stock options, but stock options clearly provide value-increasing incentives for chief executives. Year-to-year stock option grants provide incentives if the size of the grant is based on performance. More important, the change in value of unexercised stock options granted in
} 
determinadas metas e objetivos previamente estipulados em seu respectivo contrato de opção. Ressalta-se, contudo, que o condicionamento exclusivamente baseado no desempenho individual do beneficiário pode se tornar causa de questionamentos relacionados à natureza salarial do benefício, razão pela qual, nas companhias brasileiras, é pouco utilizado ou utilizado em conjunto com outros mecanismos restritivos.

A legislação brasileira atualmente em vigor é silente em relação à existência do prazo de carência para a “maturação” das opções. Egberto Lacerda Teixeira e José Alexandre Tavares Guerreiro criticam a lei brasileira e defendem a existência de prazos mínimos para o exercício da opção pelos beneficiários dos planos. Nesse sentido, sustentam que os beneficiários não podem ter indiscriminada liberdade para adquirirem ou subscreverem ações quando bem entenderem, devendo o plano aprovado em assembleia geral estabelecer o período mínimo de carência para o exercício das opções outorgadas ${ }^{227}$.

Das companhias listadas no Novo Mercado da BM\&FBovespa, aproximadamente 54\% determinam expressamente já no plano de opções os prazos de carência das opções, enquanto que as demais não tratam do assunto ou deixam a cargo do conselho de administração ou de um comitê a determinação, caso a caso, do vesting period. Das companhias com período de carência expresso, aproximadamente 94\% determinam que as opções somente poderão ser exercidas a partir de três anos após a respectiva outorga ${ }^{228}$.

Dessa forma, observa-se que em razão do silêncio da legislação brasileira aplicável, ainda não existe um padrão entre as companhias abertas listadas no Novo Mercado em relação à inclusão ou não em seus respectivos planos do período de carência aplicável às opções. Contudo, a grande maioria das companhias que preveem tal período expressamente em seus planos de opção adotam prazos não inferiores a três anos, evidenciando certo padrão de entendimento quanto à extensão de um prazo razoável para o vesting period.

\subsubsection{Período de Exercício}

O chamado período de exercício é o intervalo de tempo entre o momento em que a opção passa a ser exercível (isto é, findo o prazo de carência, se existente) e o término do

previous years also provides incentives”. MURPHY, Kevin J.; JENSEN, Michael C. Performance Pay and Top Management Incentives. In: JENSEN, Michael C. Foundations of Organizational Strategy. Harvard University, 1998. Disponível em: <http://ssrn.com/abstract=94009>. Acesso em: 15 nov. 2010. p. 10.

227 Cf. TEIXEIRA, Egberto Lacerda; GUERREIRO, José Alexandre Tavares. Das sociedades anônimas no direito brasileiro, v. 1, p. 330 e 331.

${ }^{228}$ Para detalhes das companhias analisadas, cf. o anexo à presente dissertação. 
prazo estipulado pelo plano ou pelo administrador do plano ou estabelecido no contrato de outorga firmado com o beneficiário para a aquisição ou subscrição de ações. Atingida essa data de vencimento sem o exercício da opção pelo beneficiário, decai o direito deste último de subscrever/adquirir ações da companhia.

O plano de opções da Marisa Lojas S.A., por exemplo, determina que a opção outorgada aos seus beneficiários terminará de pleno direito nos seguintes $\operatorname{casos}^{229}$ : (i) pelo exercício integral da opção pelo beneficiário; (ii) pelo decurso do prazo final para exercício estabelecido no contrato de opção; (iii) pelo desligamento ou término do vínculo do beneficiário com a companhia; (iv) pela rescisão do contrato de opção, nos casos nele previstos; e (v) nas hipóteses de desligamento do beneficiário em questão da companhia.

Duas são as modalidades de exercício dentro desse prazo - o beneficiário pode exercer a sua opção até a data de vencimento da opção, a qualquer momento ou poderá fazê-lo somente na data exata de vencimento. A doutrina convencionou denominar essas duas modalidades de opções americana e europeia, respectivamente ${ }^{230}$. Francisco Satiro de Souza Júnior ressalta que as referidas denominações não restringem a incidência dos tipos de opções aos respectivos territórios geográficos, de modo que a adoção de um determinado tipo está ligada às características do ativo e do mercado a que se referem. Acrescenta, ainda, que “pragmaticamente, as opções americanas são mais valiosas que as europeias”"231. Isto porque o titular de uma opção americana não só pode exercer a opção no vencimento (como o titular da opção europeia), mas também a qualquer momento antes do vencimento. Assim, a chamada opção americana compreende a opção europeia, sendo que o inverso não é verdadeiro. Por fim, é possível ainda citar uma última modalidade: as chamadas “opções de Bermudas”. Menos conhecidas, permitem que o beneficiário exerça as suas opções em períodos intercalados, anteriores ao termo final da opção ${ }^{232}$.

\footnotetext{
${ }^{229}$ Conforme artigo 31 do plano aprovado pela Marisa Lojas S.A. em assembleia geral extraordinária realizada em 18 de dezembro de 2009. Disponível em: <www.cvm.gov.br>. Acesso em: 09 set. 2012.

${ }^{230}$ Nesse sentido, Haroldo Malheiros Duclerc Verçosa ensina que existem dois sistemas em uso no mercado: (i) o europeu; e (ii) o norte-americano. Segundo o referido autor, "[a] opção européia somente pode ser exercida na data de vencimento, enquanto que a norte-americana dá o direito de exercício a qualquer tempo até o vencimento. Em ambos os casos, o lançador sempre permanece no pólo passivo da obrigação, subordinado ao direito do titular. Em alguns contratos de opções européias encontra-se a previsão expressa de cláusula de liquidação antecipada, segundo acordo escrito ao qual as partes venham a chegar sobre o preço da liquidação". VERÇOSA, Haroldo Malheiros Duclerc. Negócios com Opções - A Opção Flexível. Revista de Direito Mercantil, Industrial, Econômico e Financeiro, São Paulo: Malheiros, n. 114, p. 63-67, abr./jun. de 1999. p. 64 e 65.

${ }^{231}$ SOUZA JR., Francisco Satiro. Regime jurídico das opções negociadas em bolsas de valores, p. 84.

${ }^{232}$ Cf. IGLESIAS, Felipe Campana Padin. Opção de compra ou venda de ações no direito brasileiro, p. 73.
} 
A grande maioria das companhias abertas brasileiras listadas no Novo Mercado da BM\&FBovespa utiliza o método das opções americanas, isto é, é facultado ao beneficiário exercer as suas opções no momento em que julgar mais conveniente desde que compreendido no período de exercício (após o vesting period e antes do vencimento das opções).

Ainda no contexto do período de exercício, novamente é possível citar a Instrução $\mathrm{CVM} \mathrm{n}^{0} 323$, referente à definição das hipóteses de exercício abusivo do poder de controle e de infração grave. Segundo o seu artigo $1^{\circ}$, XII, é modalidade de exercício abusivo do poder de controle de companhia aberta:

a instituição de plano de opção de compra de ações, para administradores ou empregados da companhia, inclusive com a utilização de ações adquiridas para manutenção em tesouraria, deixando a exclusivo critério dos participantes do plano o momento do exercício da opção e sua venda, sem o efetivo comprometimento com a obtenção de resultados, em detrimento da companhia e dos acionistas minoritários. (Grifos ausentes no original)

Assim, tal como os períodos de carência acima mencionados, a determinação de prazos máximos para o exercício da opção também pode ser entendida como uma forma de atender ao disposto em referida instrução.

Tal como os períodos de carência, a grande maioria das companhias listadas no Novo Mercado não prevê expressamente em seus respectivos planos de opção o prazo máximo para o exercício das opções (aproximadamente 52\% das companhias com planos de opção $\operatorname{aprovados}^{233}$ ). Tais prazos costumam se iniciar no momento da outorga das opções, de modo que que abrangem os prazos de carência, salvo poucas exceções, como, por exemplo, o caso da CETIP S.A. - Balcão Organizado de Ativos e Derivativos, que estabelece o prazo de cinco anos a contar da data em que as opções passam a poder ser exercidas, isto é, do término do

\footnotetext{
233 São elas: Anhanguera Educacional Participações S.A.; Autometal S.A.; B2W - Companhia Global de Varejo; BHG S.A. - Brazil Hospitality Group; BM\&FBOVESPA - Bolsa de Valores, Mercadorias e Futuros; Brasil Brokers Participações S.A.; BR Malls Participações S.A.; Brasil Pharma S.A.; Brasilagro - Cia Brasileira de Prop Agrícolas; Camargo Correa Desenvolvimento Imobiliário S.A.; Cia Hering; Cielo S.A.; Cosan S.A. Indústria e Comércio; CR2 Empreendimentos Imobiliários S.A.; Cyrela Commercial Propert S.A. Empreendimentos e Participações; Cyrela Brazil Realty S.A. Empreendimentos e Participações; Diagnósticos da América S.A.; Equatorial Energia S.A.; Estácio Participações S.A.; Eternit S.A.; EZ Tec Empreendimentos e Participações S.A.; Gafisa S.A.; Helbor Empreendimentos S.A.; Hypermarcas S.A.; Iguatemi Empresa de Shopping Centers S.A.; International Meal Company Holdings S.A.; Iochpe Maxion S.A.; JHSF Participações S.A.; JSL S.A.; Le Lis Blanc Deux Comércio e Confecções de Roupas S.A.; Localiza Rent a Car S.A.; Log-in Logística Intermodal S.A.; Marisa Lojas S.A.; Magnesita Refratários S.A.; Metalfrio Solutions S.A.; Mills Estruturas e Serviços de Engenharia S.A.; MRV Engenharia e Participações S.A.; Odontoprev S.A.; PDG Realty S.A. Empreendimentos e Participações S.A.; Positivo Informática S.A.; Profarma Distribuidora de Produtos Farmacêuticos S.A.; Cia Providência Indústria e Comércio; Raia Drogasil S.A.; Redecard S.A.; São Carlos Empreendimentos e Participações S.A.; São Martinho S.A.; Tarpon Investimentos S.A.; Technos S.A.; Tecnisa S.A.; T4F Entretenimento S.A.; Trisul S.A.; e Viver Incorporadora e Construtora S.A.
} 
período de carência. Assim, em regra, os prazos de exercício das opções costumam ser maiores que os períodos de carência, sendo que, entre aqueles analisados e expressamente previstos nos planos, a vasta maioria (aproximadamente $49 \%{ }^{234}$ ) varia de cinco a sete anos. Cinco companhias destoam das demais: a Brookfield Incorporações S.A., a Qualicorp S.A. e a Springs Global Participações S.A. estabelecem o prazo de dez anos da data da outorga das opções para o exercício das mesmas, enquanto que a Minerva S.A. e a Tempo Participações S.A. estabelecem que o beneficiário deverá exercer sua opção em até dez anos a contar da data em que tais opções se tornaram exercíveis.

\subsubsection{1. $\quad$ Preço de Exercício e Forma de Fixação}

Para que o negócio seja interessante do ponto de vista econômico para o beneficiário, é importante que este obtenha resultados positivos a partir de sua adesão ao plano de opções. Assim, para o concreto alinhamento de interesses, o beneficiário deve obter lucros com o exercício de sua opção de compra.

A partir do momento em que o preço do ativo do beneficiário, isto é, a soma do montante equivalente ao total das ações adquiridas em razão do plano de opção, for superior ao valor investido no exercício das opções somado aos eventuais gastos com a aquisição das opções em si (prêmio), será conveniente para o beneficiário, sob o ponto de vista econômico, sua adesão ao plano de opções da companhia.

A pergunta que surge é justamente como determinar o preço de exercício da opção. Se muito alto, não será conveniente para o eventual beneficiário do plano. Por outro lado, se muito baixo, além de ser contrário aos interesses dos acionistas, pode vir a gerar prejuízos para a sociedade. O cerne do alinhamento de interesses dos planos de opção, portanto, está na adequada fixação do preço de exercício das opções outorgadas, visto que estas trazem riscos para ambas as partes: companhia e beneficiários.

\footnotetext{
234 São elas: 5 anos, Aliansce Shopping Centers S.A.; ALL - América Latina Logística S.A.; Brasil Insurance Participações e Administração S.A.; BR Properties S.A.; BRF - Brasil Foods S.A.; CETIP S.A. - Balcão Organizado de Ativos e Derivativos (da carência); Cremer S.A.; Duratex S.A.; Embraer S.A.; SLC Agrícola S.A.; Valid Soluções e Serv. Seg. Meios Pag. Ident. S.A. (a contar do fim do vesting period); 6 anos, Amil Participações S.A.; Bematech S.A.; CSU Cardsystem S.A.; Ecorodovias Infraestrutura e Logística S.A.; Fleury S.A.; Grendene S.A.; JBS S.A.; Lojas Renner S.A.; LPS Brasil - Consultoria de Imóveis S.A.; Tim Participações S.A.; e 7 anos, Lupatech S.A.; QGEP Participações S.A.
} 
Nesse sentido, a doutrina costuma distinguir três formas de preço de exercício: (i) In the Money; (ii) At the Money; e (iii) Out of the Money. As três utilizam como parâmetro o preço da ação no momento da concessão e aquele do efetivo exercício. "In the Money” corresponde à situação em que o preço de exercício é inferior ao preço da ação no momento da concessão; o preço de exercício “At the Money” é aquele igual ao preço da ação no momento da concessão; e, por fim, a situação “Out of the Money” é aquela em que o preço de exercício é superior ao preço da ação no momento de sua concessão. Elucida Haroldo Malheiros Duclerc Verçosa que essas “possibilidades demonstram, de forma cabal, que o risco em contratos dessa espécie é recíproco, devendo cada parte exercer o seu direito e cumprir sua obrigação na forma acordada, sob pena de causar irreparáveis prejuízos à outra”235.

Quanto ao risco e incerteza relacionados ao negócio da opção, Francisco Satiro de Souza Júnior esclarece que se trata de elementos presentes em qualquer atividade empresarial. Segundo o referido autor, "sempre que um indivíduo ou uma empresa se lança num empreendimento visando à obtenção de um determinado ganho, vários dos fatores que influenciam direta e indiretamente essa atividade são incertos, imprecisos e, muitas vezes, imprevisíveis quanto ao alcance e à magnitude" ${ }^{236}$. O plano de opção de compra de ações da Ecorodovias, por exemplo, antes mesmo de estabelecer seus termos e condições, apresenta um comunicado a seus beneficiários no sentido de alertá-los quanto aos riscos relacionados ao negócio de investimento em ações e às implicações de ordem tributária:

\begin{abstract}
Observação Importante: A participação neste Plano de Opção de Compra de Ações é totalmente opcional, desde que todos os critérios de elegibilidade tenham sido atendidos e todas as condições de participação tenham sido aceitas pelo Beneficiário. A compra de ações é considerada um investimento de risco, já que representa o investimento em fundos de renda variável (ex. ações publicamente negociadas). Logo, quando se investe em ações, fica-se exposto a alguns riscos, tais como: volatilidade do mercado de capitais, liquidez das ações e oscilação de suas cotações na BM\&FBOVESPA. Esses riscos associados podem trazer ganhos ou perdas. A opção de cada Beneficiário pela aquisição e, depois de certo tempo, a venda das ações da EcoRodovias, assim como os lucros (dividendos, juros, etc) que são auferidos por cada Beneficiário entre os dois eventos, pode ter consequências tributárias, especialmente a eventual incidência de imposto de renda caso haja um resultado positivo da venda das ações. Ressaltamos que a legislação tributária é dinâmica, logo, passível de sofrer alterações em sua escrita e interpretação. Cada Beneficiário deve se responsabilizar por avaliar suas condições específicas individualmente, assim como consultar seus próprios contadores para assegurar as implicações tributárias. ${ }^{237}$ (Grifos ausentes no original)
\end{abstract}

\footnotetext{
235 VERÇOSA, Haroldo Malheiros Duclerc. Negócios com Opções, p. 65.

${ }^{236}$ SOUZA JR., Francisco Satiro. Regime jurídico das opções negociadas em bolsas de valores, p. 9.

237 Conforme plano aprovado em assembleia geral extraordinária realizada em 31 de agosto de 2010. Disponível em: <www.cvm.gov.br>. Acesso em: 08 fev. 2012.
} 
Ressalta-se, ainda, que não existe na atual legislação brasileira um parâmetro específico para o caso de emissão de ações no âmbito dos planos de opção, razão pela qual, em princípio, a fixação do preço deve levar em consideração os parâmetros estabelecidos pelo artigo 170, $\S 1^{\circ}$, da Lei das Sociedades por Ações. São os seguintes os critérios legais: (i) a perspectiva de rentabilidade da companhia; (ii) o valor do patrimônio líquido da ação; e (iii) a cotação das ações da companhia em bolsa de valores ou no mercado de balcão organizado, admitido ágio ou deságio em função das condições do mercado.

Não obstante a existência dos referidos critérios, é admitida a aplicação de descontos ao preço de exercício como uma forma de incentivo adicional aos beneficiários. Tais descontos podem estar vinculados a metas de desempenho ou relacionados à rentabilidade da companhia. Paulo Cezar Aragão e Daniela Soares admitem a aplicação de descontos ao preço de exercício das opções. Como incentivo adicional à adesão aos planos de opção, afirmam os referidos autores que os descontos são justificados pela utilização de metas de comprometimento. Complementam afirmando que

[e]m alguns casos tem sido adotada a prática, a nosso ver legítima, de reconhecer, por meio de descontos mais expressivos na fixação do preço de emissão no momento da outorga, o esforço anterior acumulado - por assim dizer - dos beneficiários em levar a companhia a um certo nível de rentabilidade ou de atratividade que permite a realização de uma oferta pública inicial no mercado de valores mobiliários $^{238}$.

Assim, tendo em vista a ausência de regramento específico na legislação brasileira, recomenda-se a utilização dos critérios do artigo 170, § $1^{\circ}$, da Lei das Sociedades por Ações, sendo que descontos sobre o referido valor são admitidos. O importante no momento da aprovação do plano ou da outorga das opções é não só a determinação clara e precisa da fórmula de fixação do preço de emissão das ações objeto das opções outorgadas no âmbito dos planos, mas também a forma de integralização das ações ${ }^{239}$. Mecanismos claros de fixação de preços proporcionam aos acionistas e investidores uma forma objetiva de medir o desempenho dos administradores e empregados da sociedade, remunerando-os de acordo com a geração de valor proporcionada ao acionista. Adicionalmente, viabilizam melhor alocação de recursos, uma vez que permitem uma concorrência justa entre as companhias emissoras por oportunidade de captação de investimento ${ }^{240}$.

\footnotetext{
238 ARAGÃO, Paulo Cezar; SOARES, Daniela. Opções de Compra de Ações, p. 163.

239 Por influência norte-americana, em razão do Sarbanes-Oxley Act, a integralização em muitos dos planos de opção de compra de companhias abertas brasileiras passou a ser obrigatoriamente à vista.

${ }^{240}$ Cf. SPERCEL, Thiago A. Mercado de Capitais e Insider Trading. São Paulo, 2007. 245 f. Dissertação (Mestrado). Faculdade de Direito, Universidade de São Paulo. p. 22.
} 
Dessa forma, quanto mais claro estiver o mecanismo de fixação de preços da opção, mais eficiente será o plano - garantirá livre e adequado acesso a informações por parte dos acionistas e investidores e prevenirá negociações com base em informações privilegiadas, em observância ao princípio de informar (full disclosure).

Até o início de 2012, havia 124 companhias registradas no Novo Mercado da BM\&FBovespa. Destas, apenas 25 não possuíam um plano de opção de compra de ações aprovado; ou seja, aproximadamente $80 \%$ das companhias listadas no referido segmento possuem alguma forma de remuneração variável baseada em ações para determinados administradores, empregados ou prestadores de serviço ${ }^{241}$. O elevado número de companhias que optaram por essa forma de remuneração demonstra a preocupação das sociedades brasileiras abertas com o alinhamento de interesses e seu intuito de oferecer maiores incentivos a seus colaboradores, bem como revela uma tendência na prática atual das sociedades abertas brasileiras.

Não obstante o elevado número de sociedades que se predispõem a compartilhar os seus resultados com seus colaboradores, isto é feito com apenas um pequeno percentual do número de ações do capital social. Mais de $40 \%$ das sociedades que possuem plano de opção de compra de ações estabelecem que a quantidade máxima de ações que podem ser objeto de outorga de opções não deve ultrapassar o equivalente a $5 \%$ (exclusive) das ações representativas do capital social ${ }^{242}$. Atualmente, este percentual parece ser a referência para as

\footnotetext{
241 Para detalhes das companhias analisadas, cf. o anexo à presente dissertação.

242 Ao todo são 42 companhias: Amil Participações S.A.; Anhanguera Educacional Participações S.A.; Autometal S.A.; B2W - Companhia Global de Varejo; BM\&FBOVESPA - Bolsa de Valores, Mercadorias e Futuros; Brasilagro - Cia Brasileira de Prop Agrícolas; BRF - Brasil Foods S.A.; CETIP S.A. - Balcão Organizado de Ativos e Derivativos; Cielo S.A.; CSU Cardsystem S.A.; Diagnósticos da América S.A.; Duratex S.A.; Ecorodovias Infraestrutura e Logística S.A.; Embraer S.A.; EZ Tec Empreendimentos e Participações S.A.; Fleury S.A.; Hypermarcas S.A.; Iguatemi Empresa de Shopping Centers S.A.; JBS S.A.; LLX Logística S.A.; Marisa Lojas S.A.; M. Dias Branco S.A. Indústria e Comércio de Alimentos; MMX Mineração e Metálicos S.A.; MPX Energia S.A.; OGX Petróleo e Gás Participações S.A.; OSX Brasil S.A.; Positivo Informática S.A.; Profarma Distribuidora de Produtos Farmacêuticos S.A.; Cia Providência Indústria e Comércio; Raia Drogasil S.A.; Redecard S.A.; Rodobens Negócios Imobiliários S.A.; Rossi Residencial S.A.; São Martinho S.A.; SLC Agrícola S.A.; Tecnisa S.A.; Tim Participações S.A.; Totvs S.A.; Trisul S.A.; Valid Soluções e Serv. Seg. Meios Pag. Ident. S.A.; Viver Incorporadora e Construtora S.A.; Weg S.A.
} 
sociedades brasileiras listadas no Novo Mercado. Das 29 companhias que estabelecem o percentual máximo de ações representativas do capital social entre 5\% (inclusive) e 7,5\% para a outorga de opções ${ }^{243}$, aproximadamente $90 \%$ adotam como limite máximo o referido percentual de 5\%; ou seja, praticamente $70 \%$ de todas as companhias com planos de opção de compra de ações listadas no Novo Mercado da BM\&FBovespa limitam em até 5\% a quantidade de opções representativas de ações do capital social que podem ser outorgadas no âmbito dos planos.

Adicionalmente, é importante mencionar que: (i) a partir dos dados públicos disponibilizados não foi possível identificar o percentual máximo das ações abrangidas em quatro planos de opções ${ }^{244}$; (ii) duas companhias determinam o percentual máximo das opções conforme a quantidade de ações em circulação no mercado ${ }^{245}$; e (iii) treze companhias determinam um valor fixo de ações que podem ser emitidas ou adquiridas no âmbito de seus respectivos planos de opção de compra de ações ${ }^{246}$. Dessa forma, tendo em vista que o número de ações em circulação e que a quantidade de ações representativas do capital social de uma companhia podem variar com o tempo, não foi possível auferir o percentual máximo do capital social representativo das ações abrangidas pelos planos dessas companhias.

Ainda em relação ao limite máximo da parcela das ações do capital social que pode ser objeto de outorgas de opção de compra de ações, apenas nove companhias estabelecem um percentual igual ou superior a 7,6\%. ALL - América Latina Logística S.A., Lojas Renner S.A. e PDG Realty S.A. Empreendimentos e Participações estipulam limite que não atinge 10\% do capital social. Já a BR Malls Participações S.A., a BR Properties S.A., a Brookfield Incorporações S.A. e a Camargo Correa Desenvolvimento Imobiliário S.A. determinam o percentual exato de 10\% como limite máximo (o dobro da grande maioria das demais companhias com planos de opção listadas no Novo Mercado). Definitivamente são duas

\footnotetext{
${ }^{243}$ São elas: Aliansce Shopping Centers S.A.; Bematech S.A.; BHG S.A. - Brazil Hospitality Group; Brasil Brokers Participações S.A.; Brasil Insurance Participações e Administração S.A.; Brasil Pharma S.A.; Cia Hering; Cosan S.A. Indústria e Comércio; CR2 Empreendimentos Imobiliários S.A.; Estácio Participações S.A.; Even Construtora e Incorporadora S.A.; Gafisa S.A.; Grendene S.A.; Helbor Empreendimentos S.A.; HRT Participações em Petróleo S.A.; International Meal Company Holdings S.A.; Iochpe Maxion S.A.; JHSF Participações S.A.; JSL S.A.; LPS Brasil - Consultoria de Imóveis S.A.; Lupatech S.A.; Magnesita Refratários S.A.; Marfrig Alimentos S.A.; Mills Estruturas e Serviços de Engenharia S.A.; Minerva S.A.; Odontoprev S.A.; QGEP Participações S.A.; T4F Entretenimento S.A.; Vanguarda Agro S.A.

${ }^{244}$ Eternit S.A.; Log-in Logística Intermodal S.A.; Natura Cosméticos S.A.; São Carlos Empreendimentos e Participações S.A.

${ }^{245}$ Cyrela Commercial Propert S.A. Empreendimentos e Participações; Cyrela Brazil Realty S.A. Empreendimentos e Participações.

${ }^{246}$ Cremer S.A.; Direcional Engenharia S.A.; Equatorial Energia S.A.; Ideiasnet S.A.; Le Lis Blanc Deux Comércio e Confecções de Roupas S.A.; Light S.A.; Localiza Rent a Car S.A.; Metalfrio Solutions S.A.; MRV Engenharia e Participações S.A.; Qualicorp S.A.; Springs Global Participações S.A.; Technos S.A.; TPI Triunfo Participações e Investimentos S.A.
} 
companhias que se destacam em relação ao número máximo de ações abrangidas pelos planos de opção de compra: a Tempo Participações S.A., que, na época da aprovação do plano de opções (abril de 2007), aprovou um percentual equivalente a 12\% do seu capital social; e a Tarpon Investimentos S.A., com incríveis 25\% - um percentual absolutamente destoante das demais companhias listadas no Novo Mercado.

Das informações acima expostas é possível concluir que apesar do grande número de companhias que aprovaram planos de opção de compra, de uma forma geral, a abertura para a participação dos beneficiários ainda é bastante tímida. Muitas das companhias com controle definido optam por compartilhar apenas uma pequena parcela da participação acionária (na grande maioria das companhias, igual ou inferior a 5\% do total do capital social). No entanto, por vezes, essa pequena participação é capaz de mitigar outros riscos, como, por exemplo, o da sucessão em empresas familiares, conforme abaixo analisado.

Obviamente, em números absolutos, um pequeno percentual pode representar em moeda corrente nacional um montante bastante expressivo, isto é, uma ínfima participação concedida a um determinado beneficiário pode representar um percentual extremamente vultoso se comparado à sua remuneração. A definição da quantidade das ações abrangidas pelos planos deve se pautar não apenas pelo número de ações, mas por todo o patrimônio da companhia e perspectivas de rentabilidade e crescimento, variando e devendo ser ajustada, portanto, caso a caso. Se hoje no país a grande maioria das companhias opta por um percentual em torno de $5 \%$, esse valor pode variar - e muito - em outros países, tendo em vista as características das sociedades ali estabelecidas e das remunerações praticadas. Como já mencionado na presente dissertação, em países com o mercado de capitais desenvolvido, são frequentes os casos em que a remuneração variável de um determinado empregado é consideravelmente maior que a remuneração fixa.

Outro tema bastante relevante é a questão da transferência das ações resultantes do exercício das opções outorgadas no âmbito dos planos de opção de compra de ações. Basicamente existem duas formas de reter o profissional no âmbito de um plano de opção de compra: durante a fase de aquisição do direito de exercício (período de carência ou vesting period, conforme já analisado na presente dissertação) ou após a aquisição ou subscrição da ação (lock up period). Mais "blindado” será o plano de opção de compra de ações se existentes tais períodos (e quanto maiores forem eles). Por outro lado, a simples existência desses períodos ou a duração demasiadamente grande dos mesmos podem tornar o plano não atrativo. Assim, como o número de ações abrangidas pelo plano, os períodos de carência e de 
restrição à transferência das ações após a sua aquisição ou subscrição, deve ser ajustado conforme os melhores interesses da companhia e dos acionistas.

Especificamente em relação à transferência das ações resultantes do exercício das opções, poucos planos autorizam expressamente a livre negociação das mesmas pelo beneficiário: apenas dez das companhias listadas no Novo Mercado da BM\&FBovespa, sendo que as demais companhias ou não tratam do assunto expressamente ou deixam a cargo do conselho de administração ou de um comitê especialmente criado para a administração do plano definir, conforme o caso, os beneficiários que serão submetidos a restrições à transferência de ações, seja por meio de programas de outorga, seja em contratos de opção ${ }^{247}$.

As restrições à transferência podem ocorrer de diferentes formas. Alguns planos determinam que a própria companhia tem direito de preferência na aquisição das ações anteriormente adquiridas em virtude do plano de opções, enquanto que outros apenas autorizam a alienação de ações quando o preço de exercício estiver integralmente pago. A B2W - Companhia Global de Varejo adota um procedimento gradual de transferência pelos beneficiários das ações adquiridas no âmbito do plano. Esta companhia determina que até o $30^{\circ}$ mês subsequente à assinatura do contrato de opção pelo beneficiário, as ações não podem ser alienadas. Entre o $31^{\circ}$ e o $59^{\circ}$ mês, o beneficiário somente pode alienar o equivalente a $50 \%$ do total das ações oriundas do plano de que é titular. Somente a partir do $60^{\circ}$ mês o beneficiário está livre para negociar a totalidade das ações. Com esse mecanismo, a tendência de o beneficiário permanecer por mais tempo na companhia é maior, visto que, quanto maior o decurso do tempo, maiores serão suas perspectivas de ganho, ao passo que as companhias com planos que não possuem qualquer forma de restrição à transferência das ações adquiridas estão sujeitas a êxodos de beneficiários após o término do plano.

Ainda em relação às restrições à transferência das ações adquiridas no âmbito dos planos de opção, é importante destacar o disposto no artigo 40 da Lei das Sociedades por Ações. Segundo tal disposto legal, o usufruto, o fideicomisso, a alienação fiduciária em garantia e quaisquer cláusulas ou ônus que gravarem a ação deverão ser averbados: (i) no livro de Registro de Ações Nominativas, se se tratar de ações nominativas; e se forem ações escriturais, (ii) nos livros da instituição financeira, que os anotará no extrato da conta de depósito fornecido ao acionistas. Somente com a averbação referida é que a promessa de

\footnotetext{
${ }^{247}$ Nesse sentido, por exemplo, cabe ao conselho de administração da BM\&FBovespa determinar, ou não, um período de indisponibilidade para a transferência das ações adquiridas no âmbito do plano por determinado beneficiário, nunca sendo o referido período, contudo, superior a dois anos.
} 
venda da ação e o direito de preferência à sua aquisição são oponíveis a terceiros. Nesse sentido, tal averbação cabe ao administrador do plano e aos próprios administradores das companhias que tiverem em seus planos de opção dispositivo no sentido de restringir alguma forma de transferência das ações adquiridas. Apesar de se tratar de uma obrigação legal, dentre as empresas listadas no Novo Mercado da BM\&FBovespa analisadas ${ }^{248}$, apenas a Duratex S.A. optou por expressamente prever em seu plano a obrigação de averbação:

O titular poderá dispor livremente de metade das ações que houver subscrito mediante o exercício da opção. A outra metade ficará indisponível pelo prazo de 2 anos, contado a partir da data do exercício de opção, averbando-se essa indisponibilidade na forma e para os fins previstos no artigo 40 da Lei das Sociedades por Ações ${ }^{249}$.

\subsubsection{Os Planos de Opção e a Estrutura Familiar}

Outro aspecto interessante dos planos de opção de compra de ações é sua utilização em sociedades tradicionalmente familiares como forma de estruturar a sucessão de gerações e gerar oportunidades para a empresa crescer e prosperar. Esta é uma faceta interessante dos planos de opção de compra, pois diverge completamente do tradicional cenário disperso das sociedades norte-americanas e reflete a realidade da grande maioria das sociedades brasileiras. Independentemente da concentração acionária, contudo, os planos de opção utilizados com essa finalidade mantêm as premissas de atrair e reter profissionais, sempre em busca do melhor alinhando de interesses e desempenho societário.

Um dos principais desafios de uma sociedade com controle concentrado nas mãos de membros de uma única família definitivamente é a sucessão do seu controle acionário. A expressão norte-americana "shirtsleeves to shirtsleeves in three generations" bem reflete tal dificuldade $^{250}$. O ditado descreve a dificuldade de uma companhia familiar se manter próspera

\footnotetext{
248 Cf. o anexo à presente dissertação para a lista das companhias analisadas.

249 Conforme ata da assembleia geral extraordinária da Duratex S.A. realizada em 31 de agosto de 2009. Disponível em: <www.cvm.gov.br>. Acesso em: 14 abr. 2012.

${ }^{250}$ Em outros idiomas a expressão também pode ser identificada, como na Itália: "Dalle stalle alle stelle alle stalle" (dos estábulos às estrelas e de volta ao estábulo); no México: "Padre bodeguero; hijo millionario; nieto pordiosero" (pai comerciante, filho cavalheiro, neto mendicante), na China: "Fu bu guo san daí” (a fortuna nunca dura três gerações) e no Brasil: "Pai rico, filho nobre e neto pobre”. STALK, George; FOLEY, Henry. Evite ciladas capazes de destruir a empresa familiar. Harvard Business Review, p. 11-13, jan. 2012. p. 12.
} 
por mais de três gerações, ou seja, a tendência a ter sérios problemas quando os netos do fundador alcançarem o controle da companhia ${ }^{251}$. De fato, tal ditado tem-se mostrado verdadeiro ao passo que aproximadamente $70 \%$ das empresas com controle familiar são fechadas ou vendidas antes que a geração seguinte à do fundador chegue ao comando e apenas cerca de $10 \%$ seguem suas atividades e sob o controle da mesma família na terceira geração $^{252}$.

Diversas são as causas apontadas pela doutrina para tal taxa de insucesso ${ }^{253}$. Além da sucessão dos acionistas, é possível também citar a forma como se dá o relacionamento entre os membros da família e os demais empregados da sociedade, as opiniões conflitantes dos próprios membros da família, os ciúmes, a ausência de diálogo no processo decisório da sociedade, a falta de capacitação técnica e, em alguns casos, as participações igualitárias (comuns entre irmãos, por exemplo) de familiares com diferentes interesses, capacidades e atribuições dentro da sociedade. Assim, cada uma dessas possíveis causas de insucesso deve ser identificada e administrada ou corrigida para evitar a majoração do conflito e, assim, preservar a companhia.

\footnotetext{
251 James E. Hughes Jr., ao comentar a expressão irlandesa “Clogs to clogs in three generations” (outra variação da expressão "shirtsleeves to shirtsleeves in three generations"), explica que "[t]he first generation starts out wearing work clogs while digging in a potato field, receives no formal education, and, through very hard work, creates a fortune while maintaining a frugal lifestyle. The second generation attends university, wears fashionable clothes, has a mansion in town and an estate in the country, and eventually enters high society. The third generation's numerous members grow up in luxury, do little or no work, spend the money, and date the fourth generation to find itself back in the potato field, doing manual labor. It is a classic three-stage process: first, a period of creativity; second, a period of stasis or maintenance of the status quo; and third, a period of dissipation”. Tradução livre: “A primeira geração começa usando tamancos enquanto trabalha em uma plantação de batata, não recebe nenhuma educação formal e, através de um trabalho árduo, cria uma fortuna, mantendo um estilo de vida simples. A segunda geração frequenta a universidades, veste roupas da moda, tem uma mansão na cidade e outra propriedade no interior e, eventualmente, entra para a alta sociedade. Numerosos membros da terceira geração crescem em luxo, fazem pouco ou nenhum trabalho, gastam o dinheiro e fazem com que a quarta geração volte para a plantação de batata, fazendo trabalho manual. É um clássico processo de três gerações: primeiro, um período de criatividade; segundo, um período de estagnação ou manutenção do status quo; e terceiro, um período de dissipação”. HUGHES JR., James E. Family Wealth - keeping it in the family: how family members and their advisers preserve human, intellectual and financial assets for generations. Princeton: Bloomber, 2004. p. 3.

${ }^{252}$ Cf. STALK, George; FOLEY, Henry. Evite ciladas capazes de destruir a empresa familiar, p. 11.

253 Sobre o tema, cf. FINCH, Nigel. Identifying and Addressing the Causes of Conflict in Family Business. 2005. Disponível em: <http://ssrn.com/abstract=717262> ou <http://dx.doi.org/10.2139/ssrn.717262>. Acesso em: 09 fev. 2012; RUIZ G., Manuel; SESSAREGO, Angel R.; GUZMAN-SANZA, Ricardo L. Succession as Part of Continuity in Family Firms. 2007. Disponível em: <http://ssrn.com/abstract=1599307> ou $<$ http://dx.doi.org/10.2139/ssrn.1599307>. Acesso em: 09 fev. 2012; FINCH, Nigel. The Role of Non-Family Managers in Promoting Business Continuity in Family Owned Enterprises: Practical Conflict Resolution Techniques for Independent Managers and Non-Executive Directors. 2005. Disponível em: $<$ http://ssrn.com/abstract=902790 ou em http://dx.doi.org/10.2139/ssrn.902790>. Acesso em: 09 set. 2012; CHAMI, Ralph. What's Different about Family Businesses?. 1997. Disponível em: $<$ http://ssrn.com/abstract=38041> ou <http://dx.doi.org/10.2139/ssrn.38041>. Acesso em: 09 fev. 2012; PANUNZI, Fausto; BURKART, Mike C.; SHLEIFER, Andrei. Family Firms. Fondazione Eni Enrico Mattei Working Paper n. 74.2002; Institute of Economic Research, Harvard University, Institute Research Paper n. 19/44. Disponível em: <http://papers.ssrn.com/abstract_id=298631>. Acesso em: 09 fev. 2012.
} 
Especificamente em relação à sucessão, Fausto Panunzi, Mike C. Burkart e Andrei Shleifer afirmam que, em praticamente todas as companhias prósperas, o acionista fundador, em algum momento, deixa de controlar a companhia ${ }^{254}$. Esta transição pode ocorrer já no início da existência da companhia, como na maioria das sociedades nos Estados Unidos, ou apenas por ocasião da aposentadoria do acionista fundador, podendo ele nomear um herdeiro ou um terceiro administrador como sucessor do negócio ${ }^{255}$.

É justamente tendo em vista a segunda hipótese que, na maioria dos casos, os planos de opção de compra se ajustam à realidade brasileira e podem auxiliar no processo sucessório da companhia. Com o grau de diminuição acionária decorrente dos stock option plans controlados por meio de aprovação prévia em assembleia geral (cf. item 5.4.1 acima), as companhias brasileiras podem utilizar esse mecanismo para, paulatinamente, por meio de mecanismos de avaliação de desempenho e outorga de opções segundo metas preestabelecidas, ajustar a participação societária dos sucessores. Auferirá maiores benefícios aquele familiar que melhor desempenhar suas funções. Consequentemente, maiores são as probabilidades de a companhia continuar próspera, visto que aquele familiar desinteressado ou não qualificado não prejudicará as atividades sociais. Da mesma forma, caso o acionista fundador opte por um terceiro administrador, manterá no seio familiar o controle da companhia, sem prejuízo da administração desta e do alinhamento de interesses da família e da sociedade (administrada pelo terceiro administrador). Como já descrito no presente trabalho, o administrador, mesmo com uma participação pequena, passará a fazer parte da companhia, e com o bom desempenho da mesma, também obterá bons resultados financeiros. Em suma, todos ganham.

${ }^{254}$ Cf. PANUNZI, Fausto; BURKART, Mike C.; SHLEIFER, Andrei. Family Firms, p. 3.

255 Referidos autores explicam ainda que "[t]he patterns of separation of ownership and management vary across countries. In the United States, founders often hire professional managers early on. By the time a founder retires, his family retains only marginal ownership. In such Berle and Means (1932) corporations, professional managers exercise nearly full control. In Western Europe, significant ownership typically stays with the family after the founder retires. His children either hire a manager, as in BMW or FIAT, or run the firm themselves, as in Peugeot. In emerging markets, both management and ownership tend to stay with the family when the founder retires. Occasionally in both developed and emerging markets, a manager marries into the family, as happened at Bombardier in Canada, Matshushita in Japan, and Worldwide Shipping in Hong Kong”. Tradução livre: "os padrões da separação entre propriedade e controle variam consoante os países. Nos Estados Unidos, fundadores muitas vezes contratam gestores profissionais desde o início. No momento em que o fundador se aposenta, a sua família mantém apenas a propriedade da companhia. Em tais sociedades que seguem o padrão 'Berle e Means' (1932), gestores profissionais exercerem controle quase total. Na Europa Ocidental, a propriedade de grande parte das ações da companhia normalmente permanece com a família depois que o fundador se aposenta. Seus filhos ou contratam um gerente, como BMW ou FIAT, ou eles mesmos que passam administra a companhia, como no caso da Peugeot. Em mercados emergentes, propriedade e controle tendem a permanecer com a família quando o fundador se aposenta. Ocasionalmente, tanto nos mercados desenvolvidos, como nos mercados emergentes, o administrador pode vir a casar com algum membro da família, como aconteceu na Bombardier no Canadá, na Matshushita no Japão e na Worldwide Shipping em Hong Kong”. PANUNZI, Fausto; BURKART, Mike C.; SHLEIFER, Andrei. Family Firms, p. 3 e 4. 
Ademais, cabe destacar que a manutenção do controle familiar pode ser benéfica à sociedade, pois serve de contrapeso a medidas oportunistas de curto prazo ${ }^{256}$. Nesse sentido, George Stalk e Henry Foley defendem que

[t]ambém é bom reconhecer que o controle familiar pode ser um salutar contrapeso a incentivos de curto prazo oferecidos à maioria dos executivos. Para sobreviver a longo prazo, no entanto, a empresa familiar precisa adotar políticas formais sobre quem contratar, quem promover e como equilibrar os interesses da família e da atividade empresarial.

Nestas “políticas formais”, é possível incluir a aprovação de planos de opção de compra de ações.

${ }^{256}$ Cf. STALK, George; FOLEY, Henry. Evite ciladas capazes de destruir a empresa familiar, p. 13. 
Espera-se ter oferecido um panorama geral sobre os aspectos jurídicos societários dos planos de opção de compra de ações no Brasil. A apresentação do tema tomou como ponto de partida a discussão sobre as diferentes formas de exteriorização do controle e, por consequência, a problemática do direcionamento de condutas e do alinhamento dos interesses das diversas partes envolvidas nas companhias.

A importância das práticas de governança corporativa foi enfatizada, principalmente, pelo estudo da teoria da agência, que aponta a vulnerabilidade dos acionistas em relação aos administradores na medida em que estes gerenciam, por vezes sem controlar, a propriedade daqueles. Nesse sentido, a teoria citada apresenta como questão central a possibilidade de alinhar os interesses do principal com aqueles do agente, isto é, a reflexão sobre eventuais soluções para conflitos (ou, ao menos, a sua mitigação) relacionados à atuação do agente de acordo com as suas próprias vontades, desconsiderando o melhor interesse do principal.

Entre as diversas formas de solução dos conflitos de agência, verificou-se o plano de opção de compras de ações, capaz de minimizar os custos de monitoramento e de incentivos (também conhecidos como “custos de agência”). O que se espera nessa situação é que, mesmo com uma quantidade simbólica de ações, os beneficiários do plano passem a pensar conforme verdadeiros acionistas e ajam de forma a sempre buscar o melhor desempenho da companhia.

Ocorre, no entanto, que, após escândalos financeiros ocorridos na última década, verificou-se, no Brasil e no exterior, uma tendência no sentido de regulação do instituto. Foi retomada, assim, a discussão quanto à medida adequada de referida regulação. Um regramento excessivamente detalhado e rígido conflitaria com a própria natureza contratual dos planos de opção de compra, a qual permite que as partes envolvidas estabeleçam livremente os termos e as condições que melhor se adéquam às suas necessidades e interesses, permitindo, inclusive, adaptações a mecanismos e estruturas atualmente ainda não vislumbrados.

Assim, deve-se evitar uma regulação que torne os planos de opção inflexíveis perante as diferentes necessidades e características das mais diversas companhias abertas brasileiras, e que, não obstante, garanta maior segurança jurídica para a sua utilização. Um plano com 
complexos períodos de carência ou com várias restrições às transferências das ações resultantes do mesmo não é atrativo para os seus beneficiários. Contudo, um plano que de nenhuma forma vincule seus beneficiários perde um dos objetivos primordiais dos planos de opção de compra que é justamente o alinhamento de interesses no longo prazo e a retenção de profissionais bem qualificados, bem como dá margem a fraudes e oportunismos (como tomadas de decisão focadas exclusivamente no curto prazo).

Nesse contexto, ganham destaque as boas práticas de governança corporativa, assim como os deveres fiduciários dos administradores - que, na maioria dos casos, além de serem os próprios beneficiários, também acabam por aprovar a outorga das opções. Divulgação de informações e maior transparência nas políticas de remuneração, por exemplo, auxiliam na minimização do risco de agência, mas não o eliminam.

Ressalta-se, assim, que as práticas de governança corporativa mitigam, mas não afastam por completo, o risco de práticas oportunistas por parte de administradores em relação aos planos de opção de compra de ações.

Atualmente, a observância de deveres fiduciários ainda é a principal ferramenta de defesa da companhia e seus acionistas contra administradores. Como mencionado no presente trabalho, tratam-se de padrões de conduta (standards), pelo que ainda aspectos subjetivos são levados mais em consideração do que aspectos objetivos - os quais, por sua vez, dificultam um controle totalmente efetivo da administração dos planos de opção. O desafio atual, portanto, é a elaboração de mecanismos ou regras objetivas que auxiliem os deveres fiduciários na supervisão da conduta dos administradores dentro do contexto de um plano de opção de compra de ações (no fundo, soluções complementares para a mitigação do risco de agência).

Dessa forma, importante destacar recente trabalho sobre governança corporativa no Reino Unido. Segundo o The Kay Review of UK Equity Markets and Long-Term Decision Making - Final Report, datado de julho de $2012^{257}$, as deficiências dos planos de opção já foram reconhecidas em diversas ocasiões. Em suma, o retorno dos planos era assimétrico, visto que os beneficiários compartilhavam ganhos, mas não as perdas com os acionistas. Aqueles se beneficiavam com altas genéricas do mercado, bem como com tendências positivas em relação a um determinado setor da economia em que a companhia atuava, ou seja, aspectos não relacionados com o desempenho em si do negócio da companhia ou da

${ }^{257}$ Disponível em: <http://www.bis.gov.uk/assets/biscore/business-law/docs/k/12-917-kay-review-of-equitymarkets-final-report>. Acesso em: 29 nov. 2012. 
atuação do beneficiário em questão. Ainda segundo referido report, a ocorrência de oscilações na cotação das ações em curto prazo é o resultado muito mais de especulações quanto ao desempenho de uma companhia, do que o desempenho, de fato, da mesma. Em conclusão, a longo prazo, especulações de curto prazo e resultados a longo prazo podem variar sensivelmente.

Em face das críticas realizadas nos últimos anos em relação aos planos de opções, o estudo acima mencionado conclui que atualmente os planos devem ser projetados a longo prazo, pelo que as ações resultantes dos planos de opção devem ficar na posse do beneficiário por período consideravelmente maior que o prazo de mandato dos administradores (um exemplo de mecanismo complementar aos deveres fiduciários na supervisão da conduta dos administradores no âmbito de um plano de opção de compra de ações).

A crítica, portanto, que se pode extrair do The Kay Review é que os períodos de carência ou de restrição à transferência devem ser, no mínimo, suficientemente grandes para compreender o mandato daqueles administradores que aprovaram a outorga das opções (no caso do Reino Unido, variam entre 3 e 5 anos). A ideia por traz da recomendação é justamente evitar a tomada de decisões focadas em resultados de curto prazo que possam influenciar negativamente o desempenho da companhia no longo prazo $^{258}$.

Adicionalmente, foi abordada a discussão brasileira sobre a eventual natureza salarial dos planos de opção de compra de ações. Afirmar que estes são uma forma variável de salário é contrariar a motivo que deu causa ao surgimento dos planos de opção, que é o de alinhar interesses e atrair funcionários bem qualificados, comprometendo-os com a valorização da empresa a longo prazo (objetivo este que nada se aproxima com a retribuição de serviços prestados). Assim, a natureza salarial não pode ser atribuída a um plano corretamente estruturado - isto é, estruturado e aprovado com base nos fundamentos do direito comercial -, tendo em vista, sobretudo, o risco de perda para o beneficiário envolvido. Nesse sentido, Carla Lobo Olim Marote conclui que enquanto não houver uma definição jurídica quanto a natureza dos planos de opção, mais especificamente em relação às quantias auferidas através desse tipo de programa, as únicas precauções a serem tomadas pelos acionistas referem-se à

\footnotetext{
258 Cf. THE KAY REVIEW of UK Equity Markets And Long-Term Decision Making - Final Report. Disponível em: <http://www.bis.gov.uk/assets/biscore/business-law/docs/k/12-917-kay-review-of-equitymarkets-final-report>. Acesso em: 29 nov. 2012.
} 
necessidade do empregado assumir riscos de prejuízo ou ganho ao optar pela compra da ação, bem como disponibilizar em parte recursos próprios para tal fim ${ }^{259}$.

Assim, ao aprovar um plano de opção de compra de ações, as companhias brasileiras não devem garantir lucro aos beneficiários dos planos, bem como garantir a habitualidade do mesmo. Os planos de opção devem ainda conter regras claras, com adequada divulgação de todas as suas condições e restrições, permitindo ao beneficiário, observados os termos e condições dos planos, exercer suas opções e dispor de suas ações na forma que melhor lhe convier $^{260}$.

Dessa forma, é possível concluir que um plano bem estruturado, com observância das boas práticas de governança corporativa, bem como observância pelos administradores de seus respectivos deveres fiduciários, gera credibilidade ao mercado e confiança dos beneficiários do plano em suas regras. Portanto, não basta apenas que no momento da aprovação do plano de opção de compra de ações as regras para aquisição das opções e posterior alienação das ações sejam bem definidas, mas também que ao longo do plano não só a companhia, mas também seus beneficiários, atuem de forma diligente, observando, por exemplo, seus deveres de informar e de lealdade.

${ }^{259}$ MAROTE, Carla Lobo Olim. Participação dos empregados no capital da empresa, p. 128.

260 Cf. MAROTE, Carla Lobo Olim. Participação dos empregados no capital da empresa, p. 128. 


\section{BIBLIOGRAFIA}

ADAMEK, Marcelo Vieira von. Responsabilidade civil dos administradores de S/A/ (e as ações correlatas). São Paulo: Saraiva, 2009.

AKERLOF, George A. The Market for "Lemons": quality uncertainty and the Market Mechanism. The Quarterly Journal of Economics, v. 84, n. 3, p. 488-500, ago. 1970.

ANDRADE, Adriana; ROSSETTI, José Paschoal. Governança Corporativa: fundamentos, desenvolvimento e tendências. São Paulo: Atlas, 2004.

ANDREASSEN, Paul. The Psychology of Risk. Working paper 87, mar. 1993. Disponível em: <www.levyinstitute.org/pubs/wp/87.pdf>. Acesso em: 07 set. 2012.

ARAGÃO, Paulo Cezar; SOARES, Daniela. Opções de Compra de Ações: uma análise da evolução do instituto no Brasil. In: CASTRO, Rodrigo R. Monteiro de (Coord.). Poder de Controle e Outros Temas de Direito Societário e Mercado de capitais. São Paulo: Quartier Latin, 2010. p. 158-176.

ASCARELLI, Tullio. Problemas das sociedades anônimas e direito comparado. São Paulo: Saraiva, 1969.

ASQUINI, Alberto. Perfis da empresa. Revista de Direito Mercantil - RDM, São Paulo: Malheiros, v. 35, n. 104, p. 109-126, out./dez. 1996.

ASSIS, Araken de. Comentários ao Código Civil Brasileiro: do direito das obrigações. v. 5. ALVIM, José Manoel de Arruda; ALVIM, Thereza. Rio de Janeiro: Forense, 2007.

BAINBRIDGE, Stephen M. Corporation Law and Economics. Nova Iorque: Foundation, 2002.

BEBCHUK, Lucian Arye; FRIED, Jesse M. Executive compensation as an agency problem. Journal of Economics Perspectives, n. 17, p. 71-92, 2003. Disponível em: <http://www.law.harvard.edu/programs/olin_center/>. Acesso em: 07 fev. 2012.

BERLE JR., Adolf A.; MEANS, Gardiner C. The Modern Corporation \& Private Property. New York: Macmillan, 1933.

BM\&FBOVESPA. Disponível em: <http://www.bovespa.com.br>. Acesso em: 07 set. 2012.

BORBA, José Edwaldo Tavares. Direito Societário. 9. ed. Rio de Janeiro: Renovar, 2004.

BOULOS, Eduardo Alfred Taleb; SZTERLING, Fernando. Novo Mercado e as práticas diferenciadas de governança corporativa: exame de legalidade referente aos poderes das bolsas de valores. Revista de Direito Mercantil, São Paulo: Malheiros, v. 125, p. 96-113, jan./mar. 2002. 
BRATTON, Willian W. Berle and Means Reconsidered at the Century's Turn. Journal of Corporation Law, v. 26, n. 3, 2001. Disponível em: <http://papers.ssrn.com/paper.taf?abstract_id=255999>. Acesso em: 28 fev. 2012.

. The "Nexus of Contracts Corporation”: A Critical Appraisal. Cornell Law Review, v. 74, p. 407-465, 1989.

BULHÕES PEDREIRA, José Luiz; LAMY FILHO, Alfredo. A lei das S/A. 3. ed. Rio de Janeiro: Renovar, 1997.

CARVAlHOSA, Modesto. Comentários à Lei de Sociedades Anônimas. v. 3. São Paulo: Saraiva, 2009.

. Comentários à Lei de Sociedades Anônimas. v. 4. t. II. São Paulo: Saraiva, 2003.

.; EIRIRIK, Nelson. A Nova Lei das S/A. São Paulo: Saraiva, 2002.

CATÃO, Marcos André Vinhas. Tributação de Stock Options. Revista Dialética de Direito Tributário, v. 127, p. 57-67, abr. 2006.

CHAMI, Ralph. What's Different about Family Businesses?. 1997. Disponível em: $<$ http://ssrn.com/abstract=38041> ou <http://dx.doi.org/10.2139/ssrn.38041>. Acesso em: 09 fev. 2012.

, Robert Charles. Corporate Law. 13. reimpr. Nova Iorque: Aspen Law \& Business, 1986.

COASE, Ronald H. The nature of the firm: the firm, the market and the law. Chicago; London: University of Chicago, 1990.

COFFEE JUNIOR, John C. What caused Enron? A capsule social and economic history of the 1990's. Working Paper, n. 214, jan. 2003. Disponível em: <http://ssm.com/abstract_id=373581>. Acesso em: 27 abr. 2011.

COMISSÃO DE VALORES MOBILIÁRIOS. Disponível em: <http://www.cvm.gov.br>. Acesso em: 09 set. 2012.

COMPARATO, Fábio Konder. Aspectos Jurídicos da Macro-Empresa. São Paulo: Revista dos Tribunais, 1970.

.; SALOMÃO FILHO, Calixto. O Poder de Controle na Sociedade Anônima. 4. ed. Rio de Janeiro: Forense, 2005.

CORRÊA, Luiz Fabiano. Contratos preliminares ou pré-contratos. Revista dos Tribunais, ano 86, v. 735, jan.1997.

COX, James D.; TALLEY, Eric. Hope and Despair in the Magic Kingdom: In Re Walt Disney Company Derivative Litigation. In: MACEY, Jon. (Ed.). Iconic Cases in Corporate Law, maio 2008. 
DAL MAS, Viviane Castro Neves Pascoal M. Stock options na relação de emprego. São Paulo: LTr, 2008.

DAY, Christian C. Is there a tulip in your future?: ruminations on tulip mania and the innovative dutch futures markets. Journal des Economistes et des Etudes Humaines, v. 14, n. 2, dez. 2004. Disponível em: http://ssrn.com/abstract=946140>. Acesso em: 23 jul. 2012.

DRAGOMIR, Voicu-Dan. Highlights for a History of Corporate Governance. European Journal of Management, 2008. Disponível em: <http://papers.ssrn.com/sol3/papers.cfm?abstract_id=1114045>. Acesso em: 05 set. 2012.

EMANUEL, Steven L. Corporations. 4. ed. Nova Iorque: Aspen Law \& Business, 2009.

EASTERBROOK, Frank H.; FISCHEL, Daniel R. The Economic Structure of Corporate Law. Cambridge: Harvard University, 1991.

FAMA, Eugene F.; JENSEN, Michael C. Separation of Ownership and Control. Journal of Law and Economics, v. XXVI, jun. 1983. Disponível em: $<$ http://papers.ssrn.com/abstract=94034>. Acesso em: 09 set. 2012.

FINCH, Nigel. Identifying and Addressing the Causes of Conflict in Family Business. 2005. Disponível em: <http://ssrn.com/abstract=717262> ou <http://dx.doi.org/10.2139/ssrn.717262>. Acesso em: 09 fev. 2012.

The Role of Non-Family Managers in Promoting Business Continuity in Family Owned Enterprises: Practical Conflict Resolution Techniques for Independent Managers and Non-Executive Directors. 2005. Disponível em: <http://ssrn.com/abstract=902790 ou em http://dx.doi.org/10.2139/ssrn.902790>. Acesso em: 09 set. 2012.

FONSECA, Priscila Maria Pereira Corrêa da. As stock options e seus reflexos na fixação da pensão alimentícia e na partilha de bens. Revista IOB de Direito de Família, Porto Alegre, v. 11, n. 53, p. 67-70, abr./maio 2009.

FRANÇA, Erasmo Valladão Azevedo e Novaes. Conflitos de Interesses nas Assembléias de S.A. São Paulo: Malheiros, 1993.

Invalidade das deliberações de assembleia das S.A. São Paulo: Malheiros, 1999.

.; ADAMEK, Marcelo Vieira von. A proteção aos credores e aos acionistas no aumento de capital. Revista do Advogado, n. 96, mar. 2008.

GOMES, Orlando. Contratos. 26. ed. Rio de Janeiro: Forense, 2008.

GONÇALVES, Almir Rogério. O sistema cambial brasileiro e a implantação de programas de stock options. Revista de Direito Mercantil, Industrial, Econômico e Financeiro. São Paulo, v. 119, p. 142-154, jul./set. 2000. 
GONZÁLEZ, Luis Manuel Alonso; BONETE, Aurelio Desdentado; LUQUE, Miguel Ángel Limón; ANDRÉS, Aníbal Sánchez. Stock Options, Tres Perspectivas: Mercantil, Laboral y Fiscal. Aranzadi, 2002.

GORGA, Érica Cristina Rocha. Direito Societário brasileiro e desenvolvimento do mercado de capitais: uma perspectiva de “Direito e Economia”. São Paulo, 2005. 315 f. Tese (Doutorado em Direito). Faculdade de Direito, Universidade de São Paulo.

GREENSPAN, Alan. Stock options and related matters. Revista de Direito Bancário, do Mercado de Capitais e da Arbitragem. São Paulo: Revista dos Tribunais, ano 5, n. 17, p. 13-19, jul./set. 2002.

GUERREIRO, José Alexandre Tavares. Regime jurídico do capital autorizado. São Paulo: Saraiva, 1984.

Sobre a opção de compra de ações. Revista de Direito Mercantil, Industrial, Econômico e Financeiro. Revista dos Tribunais, São Paulo, n. 39, p. 226-230, 1980.

GUIDUGLI, João Henrique. Controle Externo Contratual - O Desenvolvimento da Empresa e os Grupos de Contratos sob o Direito Societário. São Paulo: Quartier Latin, 2006.

HALL, Brian J. Six Challenges in Designing Equity-Based Pay. Journal of Applied Corporate Finance, v. 15, 2003. Disponível em: http://ssrn.com/abstract=424170. Acesso em: 10 dez. 2010.

HANSMANN, Henry; KRAAKMAN, Reinier. Agency Problems and Legal Strategies. Yale Law School, Center for Law, Economics and Public Policy Research Paper, n. 301. Disponível em: <http://ssrn.com/abstract=616003>. Acesso em: 09 abr. 2008.

HART, Oliver; HOLMSTROM, Bengt. A theory of Firm Scope. Massachusetts Institute of Technology, Department of Economics Working Paper, n. 02-42, nov. 2002. Disponível em: <http://papers.ssrn.com/abstract_id=355860>. Acesso em: 10 jan. 2012.

HERMIDA, Antonio Tapi; FRADE, Antonio D. Tapia. Stock options (opciones sobre acciones) y planes de stock options dirigidos a los trabajadores (employee stock options plans - ESOPs). Revista de Derecho Bancário y Bursátil, Centro de Estúdios de Comunicación Econômica, n. 87, jul./set. 2002.

HOPT, Klaus J. Deveres legais e conduta ética de membros do conselho de administração e de profissionais. Trad. Erasmo Valladão A. e N. França e Mauro Moisés Kertzer. Revista de Direito Mercantil, Industrial, Econômico e Financeiro, São Paulo: Malheiros, n. 144, p. 107-119, out./dez. 2006.

HUGHES JUNIOR, James E. Family Wealth - keeping it in the family: how family members and their advisers preserve human, intellectual and financial assets for generations. Princeton: Bloomber, 2004.

IGLESIAS, Felipe Campana Padin. Opção de compra ou venda de ações no direito brasileiro: natureza jurídica e tutela executiva judicial. São Paulo, 2011. 329 f. Dissertação (Mestrado). Faculdade de Direito, Universidade de São Paulo. 
INSTITUTO BRASILEIRO DE GOVERNANÇA CORPORATIVA. Disponível em: <http://www.ibgc.org.br>. Acesso em: 10 abr. 2012.

JENSEN, Michael; MECKLING, William. Theory of the firm: managerial behavior, agency costs and ownership structure. Journal of Financial Economics, v. 3, n. 4, p. 305-360, out. 1976. Disponível em: <http://papers.ssrn.com/abstract=94043>. Acesso em: 15 abr. 2008.

JIMÉNEZ, Javier Ibáñez. Stock options: Regulación, economia, política retributiva y debate social. Dykinson, 2000.

JOSUÁ, Adriana. Governança Corporativa e Teoria da Agência. São Paulo, 2005. 176 f. Dissertação (Mestrado). Faculdade de Direito, Universidade de São Paulo.

LAMY FILHO, Alfredo. Temas de S.A. Rio de Janeiro: Renovar, 2007.

.; BULHÕES PEDREIRA, José Luiz. Direito das companhias. Rio de Janeiro: Forense, 2009.

LAUTENSCHLEGER JÚNIOR, Nilson. Os desafios propostos pela Governança Corporativa ao direito empresarial brasileiro. São Paulo: Malheiros, 2005.

LOPES, Mauro Brandão. S.A.: Títulos e Contratos Novos. São Paulo: Revista dos Tribunais, 1978.

LORIA, Eli. Estrutura e função do capital social na companhia aberta. São Paulo, 2009. 132 f. Dissertação (Mestrado). Faculdade de Direito, Universidade de São Paulo.

LUCENA, José Waldecy. Das sociedades anônimas - comentários à lei (arts. 121 a 188). v. 2. Rio de Janeiro: Renovar, 2009.

MAROTE, Carla Lobo Olim. Participação dos empregados no capital da empresa: opção de compra de ações. São Paulo, 2003. 137 f. Dissertação (Mestrado). Faculdade de Direito, Universidade de São Paulo.

MARTINS, Fran. Comentários à lei das sociedades anônimas: lei $\mathrm{n}^{\circ}$ 6.404, de 15 de dezembro de 1976. v. 2. t. II - artigos 165 a 205. Rio de Janeiro: Forense, 1978.

Comentários à lei das sociedades anônimas. 4. ed., rev. e atual. por Roberto Papini. Rio de Janeiro: Forense, 2010.

MARTINS, Sérgio Pinto. Natureza do "stock option” no Direito do Trabalho. Orientador Trabalhista: suplemento de legislação, jurisprudência e doutrina, São Paulo, v. 24, n. 11, p. 3-8, nov. 2005.

MAXIMILIANO, Carlos. Hermenêutica e Aplicação do Direito. 4. ed. Freitas Bastos, 1947. 
MELLO FRANCO, Vera Helena de; SZTAJN, Rachel. Manual de Direito Comercial: sociedade anônima e mercado de valores mobiliários. v. 2. São Paulo: Revista dos Tribunais, 2005.

MEULBROEK, Lisa K. The Efficiency of Equity-Linked Compensation: Understanding the Full Cost of Awarding Executive Stock Options. Harvard Business School Working Paper, n. 00-056. Disponível em: <http://papers.ssrn.com/sol3/papers.cfm?abstract_id=215530>. Acesso em: 31 jan. 2011.

MURPHY, Kevin J. Executive Compensation. abr. 1998. Disponível em: $<$ http://ssrn.com/abstract=163914>. Acesso em: 30 nov. 2010.

.; JENSEN, Michael C. Performance Pay and Top Management Incentives. In: JENSEN, Michael C. Foundations of Organizational Strategy. Harvard University, 1998. Disponível em: <http://ssrn.com/abstract=94009>. Acesso em: 15 nov. 2010.

MOSQUEIRA, Roberto Quiroga; BUENO, Maria Isabel Tostes da Costa. Questões atinentes à Remuneração de Administradores: Bônus, Participação nos Lucros e Stock Options. In: ROCHA, Valdir de Oliveira (Coord.). Grandes questões atuais do direito tributário. v. 14. São Paulo: Dialética, 2010. p. 312-323.

MUNHOZ, Eduardo Secchi. Empresa contemporânea e Direito Societário, Poder de Controle e Grupos de Sociedade. São Paulo: Juarez de Oliveira, 2002.

NASCIMENTO, Amauri Mascaro. Iniciação ao Direito do Trabalho. 33. ed. São Paulo: LTr, 2007.

NENOMA, Tatiana. The value of corporate votes and control benefits: a cross-country analysis. Journal of Financial Economics, v. 68, 2003, p. 325-351. Disponível em: $<$ http://ssrn.com/abstract=237809>. Acesso em: 07 jul. 2010.

O’KELLEY, Charles R.T.; THOMPSON, Robert B. Corporations and Other Business Associations - Cases and Material. 3. ed. Nova Iorque: Aspen Publishers, 1999.

OIOLI, Erik Frederico. Oferta Pública de Aquisição do Controle de Companhias Abertas. São Paulo, 2008. 202 f. Dissertação (Mestrado). Faculdade de Direito, Universidade de São Paulo.

OZHAN, Neslihan. CEO Compensation and Firm Performance: Na Empirical Investigation of UK Panel Data. School of Economics, Finance and Management, University of Bristol, 29 jul. 2007. Disponível em: <http://ssrn.com/abstract=1102703>. Acesso em: 21 ago. 2010.

PALMITER, Alan R. Corporations: examples and explanations. $5^{\text {th }}$ ed. New York: Aspen Publishers, 2006.

PANUNZI, Fausto; BURKART, Mike C.; SHLEIFER, Andrei. Family Firms. Fondazione Eni Enrico Mattei Working Paper n. 74.2002; Institute of Economic Research, Harvard University, Institute Research Paper n. 19/44. Disponível em: <http://papers.ssrn.com/abstract_id=298631>. Acesso em: 09 fev. 2012. 
PERES, Tatiana Bonatti. Opção de Compra. Curitiba: Juruá, 2011.

PINTO, Arthur R.; BRANSON, Douglas M. Understanding Corporate Law. $2^{\text {nd }}$ ed. San Francisco: Offices, 2004.

REALE, Miguel. Lições Preliminares de Direito. 22. ed. São Paulo: Saraiva, 1995.

REQUIÃO, Rubens. Curso de direito comercial. v. 1. 23. ed. São Paulo: Saraiva, 2003. Curso de Direito Comercial. v. 2. 24. ed. São Paulo: Saraiva, 2005.

RIBEIRO, Milton Nassau. Aspectos Jurídicos da Governança Corporativa. São Paulo: Quartier Latin, 2007.

ROE, Mark J. The Institutions of Corporate Governance. 01 ago. 2004. Harvard Law and Economics Discussion Paper, n. 488. Disponível em: <http://ssrn.com/abstract=612362>. Acesso em: 05 set. 2012.

ROPPO, Enzo. O contrato. Coimbra: Almedina, 1988.

RUIZ G., Manuel; SESSAREGO, Angel R.; GUZMAN-SANZA, Ricardo L. Succession as Part of Continuity in Family Firms. 2007. Disponível em: $<$ http://ssrn.com/abstract=1599307> ou $\quad<$ http://dx.doi.org/10.2139/ssrn.1599307>. Acesso em: 09 fev. 2012.

SALOMÃO FILHO, Calixto. O novo direito societário. 3. ed. São Paulo: Malheiros, 2006.

SANTOS, Aline de Menezes. Reflexões sobre a Governança Corporativa no Brasil. Revista de Direito Mercantil, Industrial, Econômico e Financeiro, n. 130, ano XLII (Nova Série) abr./jun. 2003.

SITKOFF, Robert H. An Agency Costs Theory of Trust Law. Cornell Law Review, v. 89, p. 621-84, 2004. Disponível em: <http://papers.ssrn.com/abstract=412592>. Acesso em: 16 jan. 2012.

SOCIAL SCIENCE RESEARCH NETWORK. Disponível em: <http://papers.ssrn.com>. Acesso em: 07 abr. 2012.

SOUZA JR., Francisco Satiro. Regime jurídico das opções negociadas em bolsas de valores. São Paulo, 2002. 185 f. Tese (Doutorado em Direito). Faculdade de Direito, Universidade de São Paulo.

SPERCEL, Thiago A. Mercado de Capitais e Insider Trading. São Paulo, 2007. 245 f. Dissertação (Mestrado em Direito). Faculdade de Direito, Universidade de São Paulo.

STALK, George; FOLEY, Henry. Evite ciladas capazes de destruir a empresa familiar. Harvard Business Review, p. 11-13, jan. 2012. 
SZTAJN, Rachel. Conceito de liquidez na disciplina do mercado de valores mobiliários. Revista de Direito Mercantil, industrial, Econômico e Financeiro, São Paulo, v. 41, n. 126, p. 7-30, abr./jun. 2002.

- Função Social do contrato e direito de empresa. Revista de Direito Mercantil, Industrial, Econômico e Financeiro, São Paulo: Malheiros, v. 54, n. 139, p. 29-49, jul./set. 2005.

. Sobre a natureza jurídica das opções negociadas em bolsas. Revista de Direito Mercantil, Industrial, Econômico e Financeiro, São Paulo: Malheiros, n. 105, p. 53-69, 1997.

. Teoria jurídica da empresa. São Paulo: Atlas, 2004.

; VERÇOSA, Haroldo Malheiros Duclerc. A incompletude do Contrato de Sociedade. Revista de Direito Mercantil, Industrial, Econômico e Financeiro, São Paulo: Malheiros, v. 42, n. 131, p. 7-20, jul./set. 2003.

TEIXEIRA, Egberto Lacerda; GUERREIRO, José Alexandre Tavares. Das sociedades anônimas no direito brasileiro. v. 1. São Paulo: Bushatsky, 1979.

THE KAY REVIEW of UK Equity Markets And Long-Term Decision Making - Final Report. Disponível em: <http://www.bis.gov.uk/assets/biscore/business-law/docs/k/12917-kay-review-of-equity-markets-final-report>. Acesso em: 29 nov. 2012.

THE NATIONAL CENTER FOR EMPLOYEE OWNERSHIP. A nonprofit membership organization providing unbiased information and research on broad-based employee stock plans. Disponível em: <http://www.nceo.org/main/article.php/id/43/ Acesso em: 03 set. 2012.

VALVERDE, Trajano de Miranda. Sociedades por ações. v. 2. Rio de Janeiro: Forense, 1941.

VERÇOSA, Haroldo Malheiros Duclerc. Negócios com Opções - A Opção Flexível. Revista de Direito Mercantil, Industrial, Econômico e Financeiro, São Paulo: Malheiros, n. 114, p. 63-67, abr./jun. 1999.

. Curso de Direito Comercial. v. 2. 3. ed. São Paulo: Malheiros, 2006 e 2008.

WIEDEMANN, Herbert. Gesellschaftsrecht I - Grundlagen. trad. port. de Erasmo Valladão Azevedo e Novaes França, Excerto do direito societário I - fundamentos in Revista de Direito Mercantil, Industrial, Econômico e Financeiro, São Paulo: Malheiros, n. 143, p. 66-75, jul./set. 2006.

ZAINAGHI, Domingos Sávio. Aspectos trabalhistas nos programas de “Stock Option”. Suplemento Trabalhista, Curitiba: Geneses; São Paulo: LTr, n. 54, 2000. 


\section{DECISÕES JUDICIAIS}

BRASIL. Tribunal Regional do Trabalho $-2^{\text {a }}$ Região. Acórdão n. 20030636234. Recurso Ordinário n. 42364. Processo n. 42364-2002-902-02-00. Relatora: Anelia Li Chum. 2002. Diário Oficial de Justiça: 05 dez. 2003.

BRASIL. Tribunal Regional do Trabalho $-2^{\text {a }}$ Região. Acórdão n. 20030145141. Recurso Ordinário n. 20010255561. Relator: Sérgio Pinto Martins. 2001. Diário Oficial de Justiça: 08 abr. 2003.

BRASIL. Tribunal Regional do Trabalho $-2^{\mathrm{a}}$ Região. Recurso Ordinário. Processo n. 02707200604102009. Relatora: Maria Aparecida Duenhas. 2003. Diário Oficial de Justiça: 31 mar. 2009.

BRASIL. Tribunal Superior do Trabalho. $4^{\mathrm{a}}$ Turma. Agravo de Instrumento em Recurso de Revista n. 193300-69.2010.5.03.0000. Data de Julgamento: 29 fev. 2012. Relatora: Min. Maria de Assis Calsing. Diário Eletrônico de Justiça do Trabalho: 02 mar. 2012. 


\section{ANEXO}

Relação das Companhias Abertas Analisadas Listadas no Novo Mercado da BM\&FBOVESPA ${ }^{261}$ até 12 de março de 2012 com Planos de Opção de Compra/Subscrição de Ações.

\section{\# Companhia $\quad$ Referência}

1. Aliansce Shopping Centers S.A.

2. ALL - América Latina Logística S.A.

3. Amil Participações S.A.

4. Anhanguera Educacional Participações S.A.

5. Arezzo Indústria e Comércio S.A.

6. Autometal S.A.

7. B2W - Companhia Global de Varejo

8. Bematech S.A.

9. BHG S.A. - Brazil Hospitality Group

10. BM\&FBovespa - Bolsa de Valores, Mercadorias e Futuros

11. Brasil Brokers Participações S.A.

12. Brasil Insurance Participações Administração S.A.

13. BR Malls Participações S.A.

14. Brazil Pharma S.A.
Assembleia Geral Extraordinária realizada em 12 de novembro de 2009.

Assembleia Geral Extraordinária realizada em $1^{\circ}$ de abril de 1999.

Assembleia Geral Extraordinária realizada em $1^{\circ}$ de agosto de 2008.

Assembleia Geral Extraordinária realizada em 30 de outubro de 2010.

Até 18 de fevereiro de 2011, a Arezzo Indústria e Comércio S.A. não possuía um plano de opção de compra de ações.

Assembleia Geral Extraordinária realizada em 29 de abril de 2010.

Assembleia Geral Extraordinária realizada em 31 de março de 2007.

Assembleia Geral Extraordinária realizada em 16 de março de 2007.

Assembleia Geral Extraordinária realizada em 13 de novembro de 2009.

Assembleia Geral Extraordinária realizada em 8 de meio de 2008.

Assembleia Geral Extraordinária realizada em 22 de outubro de 2010.

e Assembleia Geral Extraordinária realizada em 25 de março de 2010.

Assembleia Geral Extraordinária realizada em 9 de fevereiro de 2007.

Assembleia Geral Extraordinária realizada em 22 de março de 2011.

${ }^{261}$ Conforme termos, condições e transcrições dos próprios planos. Informações disponíveis em: $<$ http://www.bmfbovespa.com.br/cias-listadas/Empresas-

Listadas/BuscaEmpresaListada.aspx?indiceAba=2\&seg=NM\&Idioma=pt-br $>$ e $<$ www.cvm.gov.br $>$. Acesso entre: 19 fev. 2011 e 12 mar. 2012. 
15. BR Properties S.A.

16. Bco Brasil S.A.

17. Brasilagro - Cia Brasileira de Prop Agrícolas

18. BRF - Brasil Foods S.A.

19. Brookfield Incorporações S.A.

20. Camargo Correa Desenvolvimento Imobiliário S.A.

21. CCR S.A.

22. CETIP S.A. - Balcão Organizado de Ativos e Derivativos

23. Cia Hering

24. Cielo S.A.

25. Cia Saneamento de Minas Gerais - COPASA MG

26. Cosan S.A. Indústria e Comércio

27. CPFL Energia S.A.

28. CR2 Empreendimentos Imobiliários S.A.

29. Cremer S.A.

30. CSU Cardsystem S.A.

31. Cyrela Commercial Propert Empreendimentos e Participações

32. Cyrela Brazil Realty S.A. Empreendimentos e Participações
Assembleia Geral Extraordinária realizada em 30 de abril de 2008.

Até 8 de dezembro de 2010, o Banco do Brasil S.A. não possuía um plano de opção de compra de ações.

Assembleia Geral Extraordinária realizada em 29 de outubro de 2008.

Assembleia Geral Extraordinária realizada em 31 de março de 2010 e Formulário de Referência, data base 17 de dezembro de 2010.

Assembleia Geral Extraordinária realizada em 15 de agosto de 2006.

Assembleia Geral Extraordinária realizada em 30 de junho de 2009.

Assembleia Geral Extraordinária realizada em 16 de novembro de $2005^{262}$.

Assembleia Geral Extraordinária realizada em 29 de dezembro de 2010.

Assembleia Geral Extraordinária realizada em 10 de abril de 2008.

Assembleia Geral Extraordinária realizada em 29 de abril de 2011.

Até 5 de abril de 2011, a Cia Saneamento de Minas Gerais - COPASA MG não possuía um plano de opção de compra de ações.

Assembleia Geral Ordinária e Extraordinária realizada em 30 de agosto de 2005.

Até 29 de março de 2011, a CPFL Energia S.A. não possuía um plano de opção de compra de ações.

Assembleia Geral Extraordinária realizada em 13 de março de 2007.

Assembleia Geral Extraordinária realizada em 23 de abril de 2009.

Assembleia Geral Extraordinária realizada em 2 de abril de 2007.

S.A. Assembleia Geral Extraordinária realizada em 28 de abril de 2008.

Assembleia Geral Extraordinária realizada em 29 de abril 2008.

262 Observação: não se trata de um plano de opção de compra de ações propriamente dito, mas sim de um Plano de Incentivo de Longo Prazo (ILP) que permite a algum dos diretores a aquisição de direitos junto à Companhia, cuja valorização se determina com base na valorização das ações, na geração de caixa e na taxa de dividendos distribuídos. 
33. Diagnósticos da América S.A.

34. Direcional Engenharia S.A.

35. Duratex S.A.

36. Ecorodovias Infraestrutura e Logística S.A.

37. Embraer S.A.

38. EDP - Energia do Brasil S.A.

39. Equatorial Energia S.A.

40. Estácio Participações S.A.

41. Eternit S.A.

42. Even Construtora e Incorporadora S.A.

43. EZ Tec Empreendimentos e Participações S.A.

44. Fertilizantes Heringer S.A.

45. Fibria Celulose S.A.

46. Fleury S.A.

47. Gafisa S.A.

48. General Shopping Brasil S.A.

49. Grendene S.A.

50. Helbor Empreendimentos S.A.

51. HRT Participações em Petróleo S.A.

52. Hypermarcas S.A.
Assembleia Geral Extraordinária realizada em 5 de janeiro de 2011.

Assembleia Geral Extraordinária realizada em 22 de dezembro de 2009.

Assembleia Geral Extraordinária realizada em 31 de agosto de 2009.

Assembleia Geral Extraordinária realizada em 31 de agosto de 2010.

Assembleia Geral Extraordinária realizada em 19 de abril de 2010.

Até 15 de abril de 2011, a EDP - Energia do Brasil S.A. não possuía um plano de opção de compra de ações.

Assembleia Geral Extraordinária realizada em 16 de outubro de 2008.

Assembleia Geral Extraordinária realizada em 13 de junho de 2008.

Assembleia Geral Extraordinária realizada em 22 de fevereiro de 2006.

Assembleia Geral Extraordinária realizada em 13 de fevereiro de 2007.

Assembleia Geral Extraordinária realizada em 3 de março de 2007.

Até 15 de setembro de 2010, a Fertilizantes Heringer S.A. não possuía um plano de opção de compra de ações.

Até 7 de abril de 2011, a Fibria Celulose S.A. não possuía um plano de opção de compra de ações.

Assembleia Geral Extraordinária realizada em 12 de novembro de 2009.

Assembleia Geral Extraordinária realizada em 18 de junho de 2008.

Até 3 de março de 2011, a General Shopping Brasil S.A. não possuía um plano de opção de compra de ações.

Assembleia Geral Extraordinária realizada em 14 de abril de 2008.

Assembleia Geral Extraordinária realizada em 8 de outubro de 2007.

Assembleia Geral Extraordinária realizada em 27 de abril de 2011.

Assembleia Geral Extraordinária realizada em 6 de setembro de 2009. 
53. Ideiasnet S.A.

54. Iguatemi Empresa de Shopping Centers S.A.

55. International Meal Company Holdings S.A.

56. Indústrias Romi S.A.

57. Iochpe Maxion S.A.

58. JBS S.A.

59. JHSF Participações S.A.

60. JSL S.A.

61. Le Lis Blanc Deux Comércio e Confecções de Roupas S.A.

62. Light S.A.

63. LLX Logística S.A.

64. Localiza Rent a Car S.A.

65. Log-in Logística Intermodal S.A.

66. Marisa Lojas S.A.

67. Lojas Renner S.A.

68. LPS Brasil - Consultoria de Imóveis S.A.

69. Lupatech S.A.

70. M. Dias Branco S.A. Indústria e Comércio de Alimentos

71. Magnesita Refratários S.A.

72. Marfrig Alimentos S.A.

73. Mahle-Metal Leve S.A.
Assembleia Geral Extraordinária realizada em 11 de junho de 2008.

Assembleia Geral Extraordinária realizada em 8 de novembro de 2006.

Assembleia Geral Extraordinária realizada em 15 de fevereiro de 2011.

Até $1^{\circ}$ de abril de 2011, a Indústrias Romi S.A. não possuía um plano de opção de compra de ações.

Assembleia Geral Extraordinária realizada em 1 de dezembro de 2009.

Assembleia Geral Extraordinária realizada em 9 de março de 2007.

Assembleia Geral Extraordinária realizada em 14 de março de 2007.

Assembleia Geral Extraordinária realizada em 8 de fevereiro de 2010.

Assembleia Geral Extraordinária realizada em 21 de janeiro de 2008.

Assembleia Geral Extraordinária realizada em 3 de março de 2008.

Assembleia Geral Extraordinária realizada em 11 de outubro de 2007.

Assembleia Geral Extraordinária realizada em 26 de abril de 2006.

Assembleia Geral Extraordinária realizada em 9 de março de 2010.

Assembleia Geral Extraordinária realizada em 18 de dezembro de 2009.

Assembleia Geral Extraordinária realizada em 30 de março de 2009.

Assembleia Geral Extraordinária realizada em 7 de novembro de 2006.

Assembleia Geral Extraordinária realizada em 13 de agosto de 2008.

Assembleia Geral Extraordinária realizada em 4 de dezembro de 2006.

Assembleia Geral Extraordinária realizada em 24 de março de 2008.

Assembleia Geral Extraordinária realizada em 29 de maio de 2009.

Até 10 de fevereiro de 2012, a Mahle-Metal Lese S.A. não possuía um plano de opção de compra de ações. 
74. Metalfrio Solutions S.A.

75. Mills Estruturas e Serviços de Engenharia S.A.

76. Minerva S.A.

77. MMX Mineração e Metálicos S.A.

78. MPX Energia S.A.

79. MRV Engenharia e Participações S.A.

80. Múltiplus S.A.

81. Natura Cosméticos S.A.

82. Odontoprev S.A.

83. OGX Petróleo e Gás Participações S.A.

84. Obrascon Huarte Lain Brasil S.A.

85. OSX Brasil S.A.

86. Paranapanema S.A.

87. PDG Realty S.A. Empreendimentos Participações

88. Porto Seguro S.A.

89. Portobello S.A.

90. PortX Operações Portuárias S.A.

91. Positivo Informática S.A.

92. Profarma Distribuidora de Produtos Farmacêuticos S.A.

93. Cia Providência Indústria e Comércio
Assembleia Geral Extraordinária realizada em 15 de março de 2007.

Assembleia Geral Extraordinária realizada em 8 de fevereiro de 2010.

Assembleia Geral Extraordinária realizada em 1 de outubro de 2008.

Assembleia Geral Extraordinária realizada em 28 de abril de 2006.

Assembleia Geral Extraordinária realizada em 26 de novembro de 2007.

Assembleia Geral Extraordinária realizada em 2 de abril de 2007.

Até 10 de janeiro de 2011, a Múltiplus S.A. não possuía um plano de opção de compra de ações.

Assembleia Geral Extraordinária realizada em 23 de março de 2009.

Assembleia Geral Extraordinária realizada em 19 de abril de 2007.

Assembleia Geral Extraordinária realizada em 30 de abril de 2008.

Até 16 de maio de 2011, a Obrascon Huarte Lain Brasil S.A. não possuía um plano de opção de compra de ações.

Assembleia Geral Extraordinária realizada em 26 de janeiro de 2010.

Até 23 de janeiro de 2012, a Paranapanema S.A. não possuía um plano de opção de compra de ações.

e Assembleia Geral Extraordinária realizada em 21 de dezembro de 2007.

Até 6 de abril de 2011, a Porto Seguro S.A. não possuía um plano de opção de compra de ações.

Até 9 de maio de 2011, a Portobello S.A. não possuía um plano de opção de compra de ações.

Até 13 de abril de 2011, a PortX Operações Portuárias S.A. não possuía um plano de opção de compra de ações.

Assembleia Geral Extraordinária realizada em 3 de novembro de 2006.

Assembleia Geral Extraordinária realizada em 2 de outubro de 2006.

Assembleia Geral Extraordinária realizada em 11 de maio de 2007. 
94. QGEP Participações S.A.

95. Qualicorp S.A.

96. Raia Drogasil S.A.

97. Redecard S.A.

98. Redentor Energia S.A.

99. Renar Maças S.A.

100. Rodobens Negócios Imobiliários S.A.

101. Rossi Residencial S.A.

102. Cia Saneamento Básico do Estado de São Paulo - Sabesp

103. São Carlos Empreendimentos e Participações S.A.

104. São Martinho S.A.

105. Sonae Sierra Brasil S.A.

106. SLC Agrícola S.A.

107. Springs Global Participações S.A.

108. Tarpon Investimentos S.A.

109. Technos S.A.

110. Tecnisa S.A.

111. Tegma Gestão Logística S.A.

112. Tempo Participações S.A.

113. Tereos Internacional S.A.

114. TIM Participações S.A.
Assembleia Geral Extraordinária realizada em 29 de abril de 2011.

Assembleia Geral Extraordinária realizada em 30 de maio de 2011.

Assembleia Geral Extraordinária realizada em 10 de novembro de 2011.

Assembleia Geral Extraordinária realizada em 15 de abril de 2010.

Até 9 de maio de 2011, a Redentor Energia S.A. não possuía um plano de opção de compra de ações.

Até 31 de agosto de 2010, a Renar Maças S.A. não possuía um plano de opção de compra de ações.

Assembleia Geral Extraordinária realizada em 4 de janeiro de 2007.

Assembleia Geral Extraordinária realizada em 3 de março de 2008.

Até 19 de maio de 2011, a Sabesp não possuía um plano de opção de compra de ações.

Assembleia Geral Extraordinária realizada em 29 de setembro de 2006.

Assembleia Geral Extraordinária realizada em 26 de março de 2009.

Até 4 de maio de 2011, a Sonae Sierra não possuía um plano de opção de compra de ações.

Assembleia Geral Extraordinária realizada em 23 de maio de 2007.

Assembleia Geral Extraordinária realizada em 24 de janeiro de 2006.

Assembleia Geral Extraordinária realizada em 16 de fevereiro de 2009.

Assembleia Geral Extraordinária realizada em 29 de abril de 2011.

Assembleia Geral Extraordinária realizada em 4 de julho de 2006.

Até 13 de abril de 2011, a Tegma não possuía um plano de opção de compra de ações.

Assembleia Geral Extraordinária realizada em 30 de abril de 2007.

Até 25 de maio de 2011, a Tereos não possuía um plano de opção de compra de ações.

Assembleia Geral Extraordinária realizada em 5 de agosto de 2011. 
115. T4F Entretenimento S.A.

116. Totvs S.A.

117. Tractebel Energia S.A.

118. Trisul S.A.

119. TPI - Triunfo Participações e Investimentos S.A.

120. Ultrapar Participações S.A.

121. Vanguarda Agro S.A.

122. Valid Soluções e Serv. Seg. Meios Pag. Ident. S.A.

123. Viver Incorporadora e Construtora S.A.

124. Weg S.A.
Assembleia Geral Extraordinária realizada em 13 de janeiro de 2011.

Assembleia Geral Extraordinária realizada em 26 de novembro de 2007.

Até 31 de maio de 2011, a Tractebel não possuía um plano de opção de compra de ações.

Assembleia Geral Extraordinária realizada em 14 de setembro de 2007.

Assembleia Geral Extraordinária realizada em 29 de junho de 2007.

Até 12 de setembro de 2011, a Ultrapar Participações S.A. não possuía um plano de opção de compra de ações.

Assembleia Geral Extraordinária realizada em 30 de abril de 2009.

Assembleia Geral Extraordinária realizada em 31 de março de 2006.

Assembleia Geral Extraordinária realizada em 12 de agosto de 2010

Assembleia Geral Extraordinária realizada em 22 de fevereiro de 2011. 